\title{
National Assessment of Shoreline Change: Historical Shoreline Change in the Hawaiian Islands
}

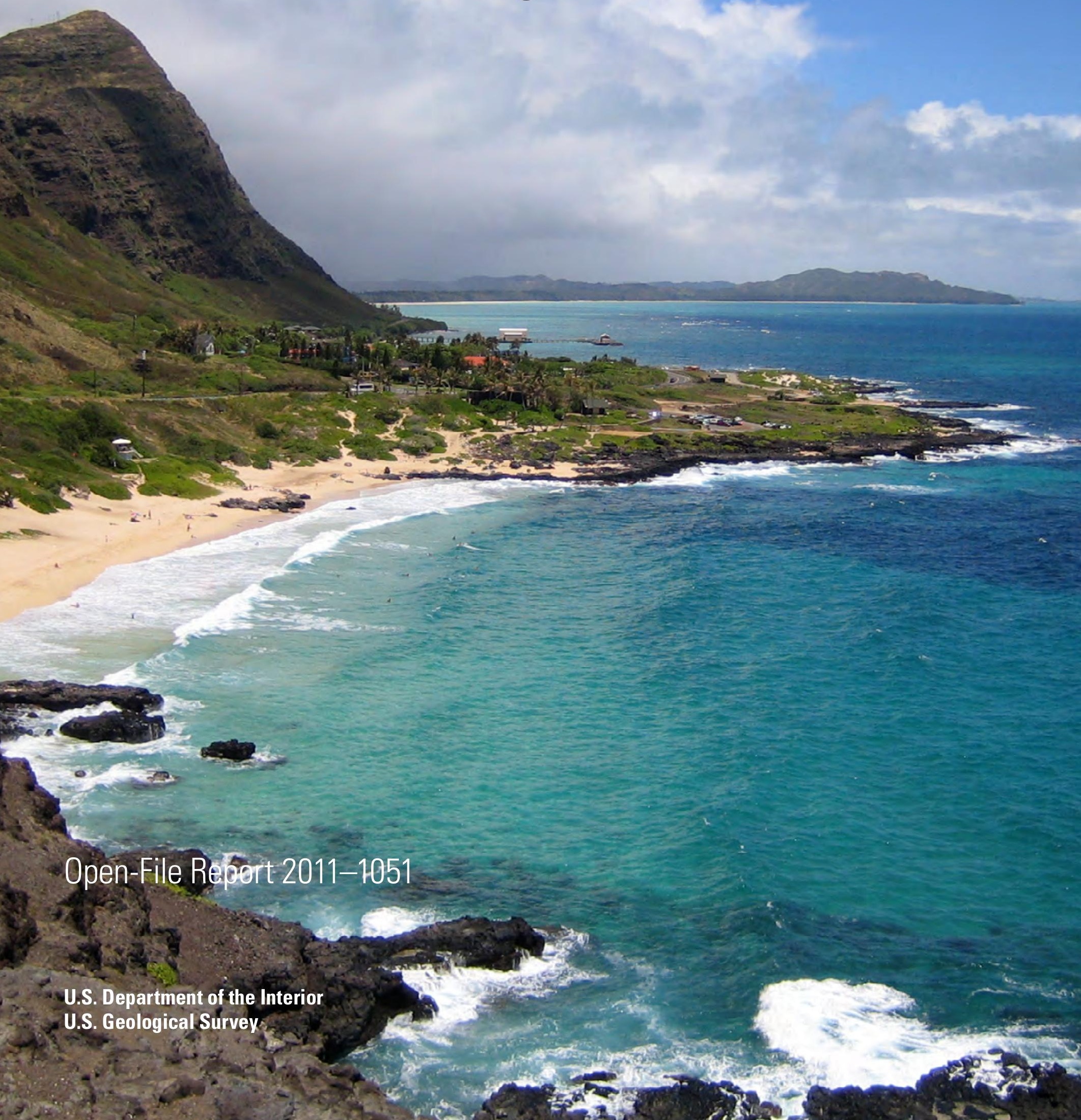


Cover. View looking northwest of Makapuu Beach Park (foreground) and Waimanalo Bay in the distance, southeast Oahu, Hawaii. 


\section{National Assessment of Shoreline Change: Historical Shoreline Change in the Hawaiian Islands}

By Charles H. Fletcher, Bradley M. Romine, Ayesha S. Genz, Matthew M. Barbee, Matthew Dyer, Tiffany R. Anderson, S. Chyn Lim, Sean Vitousek, Christopher

Bochicchio, and Bruce M. Richmond

Open-File Report 2011-1051 


\title{
U.S. Department of the Interior \\ KEN SALAZAR, Secretary \\ U.S. Geological Survey \\ Marcia K. McNutt, Director
}

\author{
U.S. Geological Survey, Reston, Virginia: 2012
}

For more information on the USGS - the Federal source for science about the Earth, its natural and living resources, natural hazards, and the environment, visit http://www.usgs.gov or call 1-888-ASK-USGS.

For an overview of USGS information products, including maps, imagery, and publications, visit http://www.usgs.gov/pubprod

To order this and other USGS information products, visit http://store.usgs.gov

Any use of trade, product, or firm names is for descriptive purposes only and does not imply endorsement by the U.S. Government.

Although this report is in the public domain, permission must be secured from the individual copyright owners to reproduce any copyrighted materials contained within this report.

Suggested citation:

Fletcher, C.H., Romine, B.M., Genz, A.S., Barbee, M.M., Dyer, Matthew, Anderson, T.R., Lim, S.C., Vitousek, Sean, Bochicchio, Christopher, and Richmond, B.M., 2012, National assessment of shoreline change: Historical shoreline change in the Hawaiian Islands: U.S. Geological Survey Open-File Report 2011-1051, 55 p. (Also available at http://pubs.usgs.gov/of/2011/1051.) 


\section{Executive Summary}

Beach erosion is a chronic problem along most open-ocean shores of the United States. As coastal populations expand and community infrastructure comes under increasing threat from erosion, there is a demand for accurate information about trends and rates of shoreline movement, as well as a need for a comprehensive analysis of shoreline movement that is consistent from one coastal region to another. To meet these national needs, the U.S. Geological Survey began an analysis to document historical shoreline change along open-ocean sandy shores of the conterminous United States and parts of Hawaii and Alaska. An additional purpose of this work is to develop systematic methodology for mapping and analyzing shoreline movement so that consistent periodic updates regarding coastal erosion can be made nationally.

This report on shoreline change on three of the eight main Hawaii islands (Kauai, Oahu, and Maui) is one in a series of reports on shoreline change in coastal regions of the United States that currently include California, the Gulf of Mexico region, the Southeast Atlantic Coast, and the Northeast Atlantic Coast. The report summarizes the methods of analysis, documents and interprets the results, explains historical trends and rates of change, and describes the response of various communities to coastal erosion. Shoreline change in Hawaii was evaluated by comparing historical shorelines derived from topographic surveys and processed vertical aerial photography over time. The historical shorelines generally represent the past century (early 1900s-2000s). Linear regression was used to calculate rates of change with the single-transect method: long-term rates were calculated from all shorelines (from the early 1900s to the most recent), whereas short-term rates were calculated from post-World War II shorelines only.

Beach erosion is the dominant trend of shoreline change in Hawaii. However, shoreline change is highly variable along Hawaii beaches with cells of erosion and accretion typically separated by only a few hundred meters on continuous beaches or by short headlands that divide the coast into many small embayments. The beaches of Kauai, Oahu, and Maui are eroding at an average long-term rate for all transects (shoreline measurement locations) of $-0.11 \pm 0.01 \mathrm{~m} / \mathrm{yr}$ (meters per year) and an average short-term rate of $-0.06 \pm 0.01 \mathrm{~m} / \mathrm{yr}$. The majority, or 70 percent, of transects on the three islands indicate a trend of erosion in the long term and 63 percent indicate a trend of erosion in the short term. A total of 22 kilometers of beach, or 9 percent of the total length of beach studied, was completely lost to erosion over the past century. Annual erosion is greatest on Maui with an average long-term shoreline change rate of $-0.17 \pm$ $0.01 \mathrm{~m} / \mathrm{yr}$ and erosion at 85 percent of transects. Short-term analysis for Maui indicates a similar erosional trend with an average rate of $-0.15 \pm 0.01 \mathrm{~m} / \mathrm{yr}$ and erosion at 76 percent of transects. Nearly 7 kilometers (11 percent) of beach was completely lost to erosion in the analysis period on Maui. Annual erosion for all transects on Kauai is intermediate in the long term, with an average rate of $-0.11 \pm 0.01 \mathrm{~m} / \mathrm{yr}$ and erosion at 71 percent of transects. The short-term average rate for Kauai ( $0.02 \pm 0.02 \mathrm{~m} / \mathrm{yr})$ suggests stable or accreting beaches; though, the majority (57 percent) of transects indicate a trend of erosion. Six kilometers or 8 percent of Kauai beaches were completely lost to erosion in the analysis period. Oahu beaches are the least erosional of the three islands in the long term; though, erosion is still the dominant trend of shoreline change with an average long-term rate of $-0.06 \pm 0.01 \mathrm{~m} / \mathrm{yr}$ and erosion at 60 percent of transects. Shoreline change trends on 0 ahu beaches are roughly the same in the short term as in the long term with an average rate of $-0.05 \pm 0.01 \mathrm{~m} / \mathrm{yr}$ and erosion at 58 percent of transects. The single-transect method of rate calculation indicates that erosion rates are statistically significant (95-percent confidence interval) at 30 percent of transects in the long term and 22 percent of transects in the short term. 
THIS PAGE INTENTIONALLY LEFT BLANK 


\section{Contents}

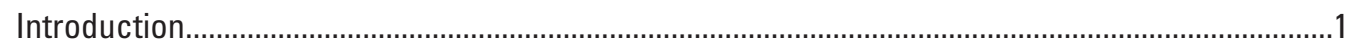

U.S. Geological Survey National Assessment of Shoreline Change .......................................1

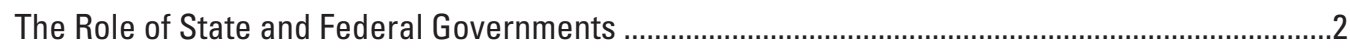

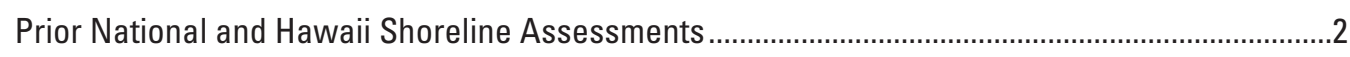

Environmental Framework of the Hawaiian Shoreline ..................................................................

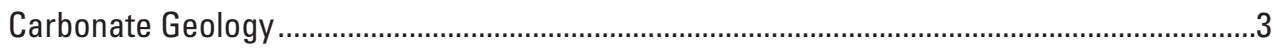

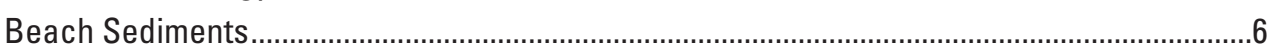

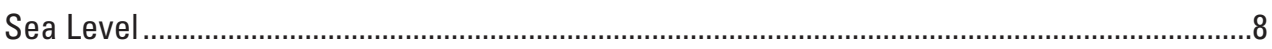

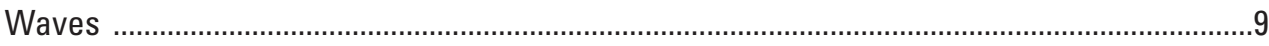

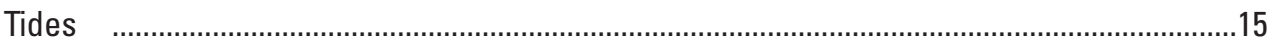

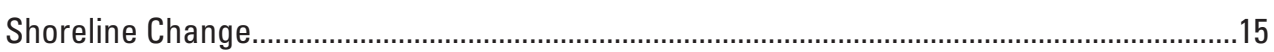

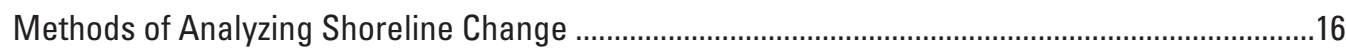

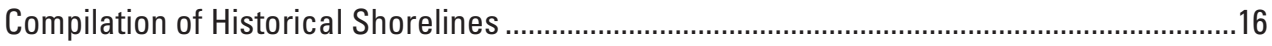

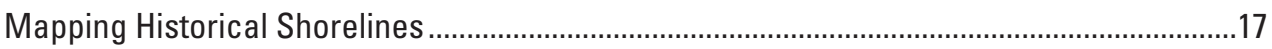

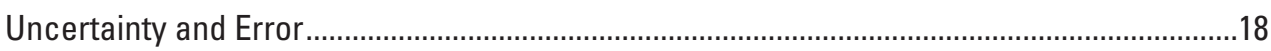

Calculation and Presentation of Rates of Change ………..................................................19

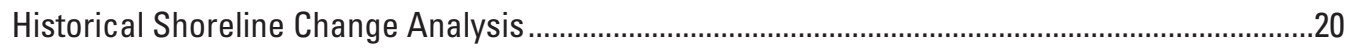

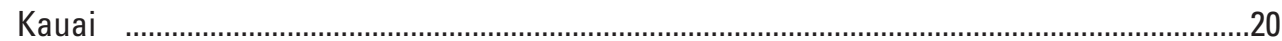

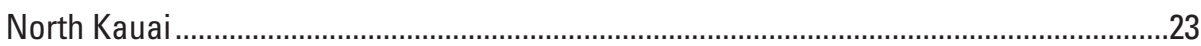

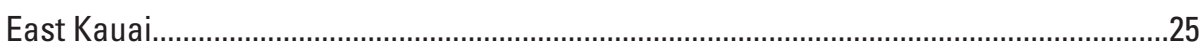

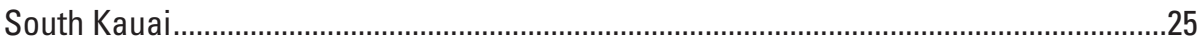

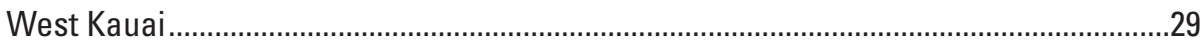

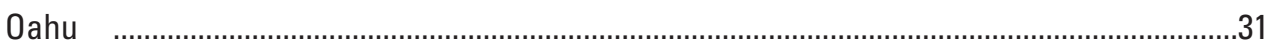

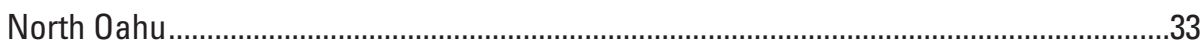

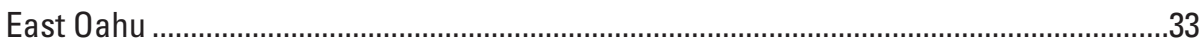

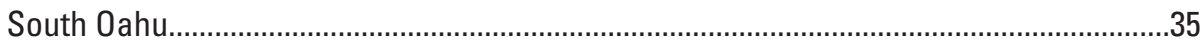

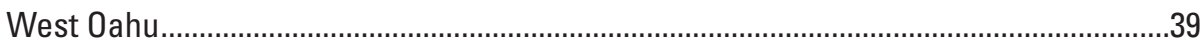

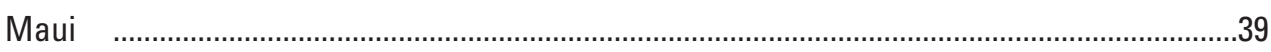

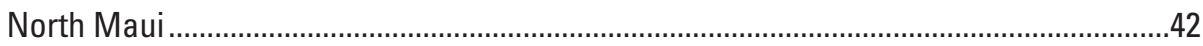

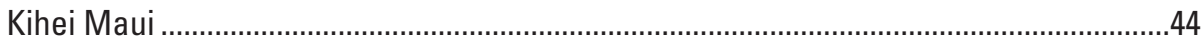

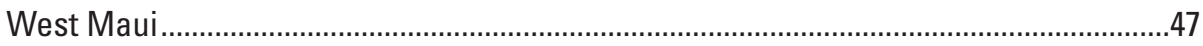

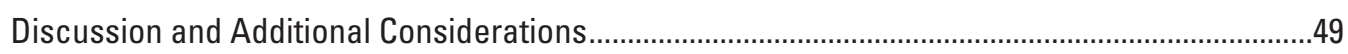

Summary of Shoreline Changes .....................................................................................

Influences of Human Activities ............................................................................................50

Planned Updates and Related Research ..........................................................................50

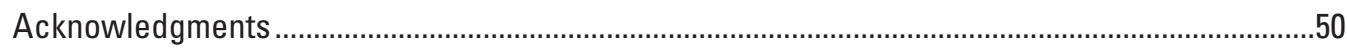

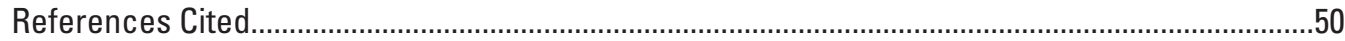




\section{Figures}

1. Computer-generated relief models of the Hawaii Island Archipelago and its northern arm, the Emperor Seamount Chain

2. Schematic diagram showing principal stratigraphic components of the Oahu carbonate shelf...

3. Aerial photograph showing carbonate sand beaches in Hawaii are the result of reef bioerosion and direct production of calcareous material by reef organisms....................5

4. Bar graph showing volume of sediment by depth zone in Kailua Bay, Oahu ...................8

5. Computer-generated relief model of Kailua Bay, Oahu..................................................

6. Graphs showing mean-sea-level trends at $A$, Hilo, 1927-2010; B, Kahului 1947-2010; C, Honolulu 1905-2010; and D, Nawiliwili, 1955-2010, Hawaii.

7. Ground photograph showing the narrow beach at Waikiki is threatened by erosion (Waikiki, Oahu; location shown in figure 29).

8. Schematic diagram showing dominant swell regimes and wave-monitoring buoy locations in Hawaii......

9. Satellite images (JASON-1) showing derived average wave height over the North Pacific in summer and winter...

10. Graph showing daily average significant wave height from buoy 51001 (1981 to 2005).14

11. Bar graph showing number of days per season that trade winds occur with a particular speed (data from buoy 51001, 1981 to 2005).

12. Schematic diagrams showing seasonal beach-profile adjustments induced by seasonal swell variations and resulting cross-shore sediment transport...

13. Aerial photograph showing historical shorelines and shore-perpendicular transects (20-meter spacing) displayed on a portion of a recent (2006) aerial photograph of Mokuleia Beach, North Oahu.....

14. Graph showing calculation of shoreline change rate from a time series of shoreline

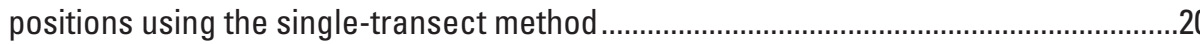

15. Index map showing four regions of Kauai: north, east, south, and west.........................21

16. Graphs showing long-term (all available years) and short-term (1940s to present) shoreline change rates, North Kauai

17. Graphs showing long-term (all available years) and short-term (1940s to present) shoreline change rates, East Kauai.

18. Oblique aerial photograph of eolianite headland (lithified carbonate sand dunes), Mahaulepu, South Kauai

19. Graphs showing long-term (all available years) and short-term (1940s to present) shoreline change rates, South Kauai.

20. Oblique aerial photograph of dunes at the west end of the Mana coastal plain, West Kauai.

21. Graphs showing long-term (all available years) and short-term (1940s to present) shoreline change rates, West Kauai.

22. Index map showing four regions of Oahu: north, east, south, and west..........................31

23. Oblique aerial photograph of limestone headlands at Kahuku Point and Kuilima (Turtle Bay), North Oahu.

24. Graphs showing long-term (all available years) and short-term (1940s to present) shoreline change rates, North Oahu.

25. Oblique aerial photograph of Lanikai and Kailua Beaches, East Oahu. 35

26. Graphs showing long-term (all available years) and short-term (1940s to present) shoreline change rates, East Oahu. 
27. Aerial photograph of the south end of Kahuku Beach, northeast Oahu, 1949, showing evidence of sand mining .37

28. Oblique aerial photograph of engineered shoreline at Waikiki, South Oahu ...................37

29. Graphs showing long-term (all available years) and short-term (1940s to present) shoreline change rates, South Oahu

30. Graphs showing long-term (all available years) and short-term (1940s to present) shoreline change rates, West Oahu .................................................................................40

31. Oblique aerial photograph of Maili Beach, West Oahu ....................................................41

32. Index map showing three regions of Maui: north, Kihei, and west ................................41

33. Graphs showing long-term (all available years) and short-term (1940s to present) shoreline change rates, North Maui

34. Oblique aerial photograph of North Maui beaches, looking west from Paia toward Baldwin Park....

35. Graphs showing long-term (all available years) and short-term (1940s to present) shoreline change rates, Kihei, Maui.

36. Oblique aerial photograph of Maalaea Bay Beach with dunes and wetlands, north Kihei coast, Maui....

37. Oblique aerial photograph of Makena Beach, southern Kihei coast, Maui ....................46

38. Graphs showing long-term (all available years) and short-term (1940s to present) shoreline change rates, West Maui

39. Oblique aerial photograph of Kaanapali Beach, West Maui

\section{Tables}

1. Relation of littoral sand grain size to shoreline aspect (wind and wave exposure) in Hawaii

2. Observed maximum annually recurring significant wave heights $\left(\mathrm{H}_{\mathrm{s}}\right)$ and the largest 10-percent $\left(\mathrm{H}_{1 / 10}\right)$ and 1-percent $\left(\mathrm{H}_{1 / 100}\right)$ wave heights for various directions around Hawaii

3. Range of errors in position of historical shorelines for Kauai, Oahu, and Maui..............18

4. Number and range in years of historical shorelines for long- and short-term shoreline change analysis on Kauai.

5. Shoreline change trends for Kauai, Oahu, and Maui .....................................................22

6. Maximum shoreline change rates on Kauai ...................................................................23

7. Average shoreline change rates for Kauai subregions ................................................25

8. Number and range in years of historical shorelines for long- and short-term

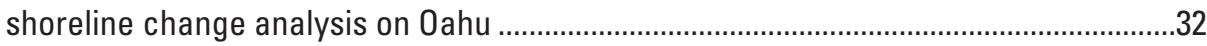

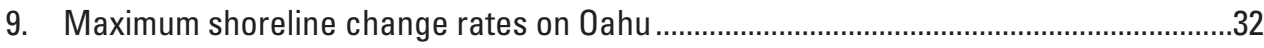

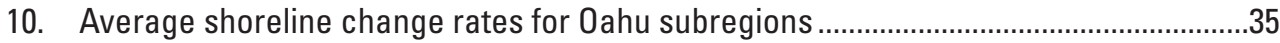

11. Number and range in years of historical shorelines for long- and short-term shoreline change analysis on Maui........................................................................................42

12. Average shoreline change rates for Maui subregions ...................................................42

13. Maximum shoreline change rates on Maui ......................................................................4 
THIS PAGE INTENTIONALLY LEFT BLANK 


\title{
National Assessment of Shoreline Change: Historical Shoreline Change in the Hawaiian Islands
}

\author{
By Charles H. Fletcher', Bradley M. Romine', Ayesha S. Genz', Matthew M. Barbee', Matthew Dyer', \\ Tiffany R. Anderson', S. Chyn Lim' ', Sean Vitousek', Christopher Bochicchio', and Bruce M. Richmond ${ }^{2}$
}

\section{Introduction}

\section{U.S. Geological Survey National Assessment of Shoreline Change}

Sandy beaches of the United States are some of the most popular tourist and recreational destinations. Coastal property constitutes some of the most valuable real estate in the country. Beaches are an ephemeral environment between water and land with unique and fragile natural ecosystems that have evolved in equilibrium with the ever-changing winds, waves, and water levels. Beachfront lands are the site of intense residential and commercial development even though they are highly vulnerable to several natural hazards, including marine inundation, flooding and drainage problems, effects of storms, sea-level rise, and coastal erosion. Because the U.S. population continues to shift toward the coast where valuable coastal property is vulnerable to erosion, the U.S. Geological Survey (USGS) is conducting a national assessment of coastal change. One aspect of this effort, the National Assessment of Shoreline Change, uses shoreline position as a proxy for coastal change because shoreline position is one of the most commonly monitored indicators of environmental change (for example, Fletcher, 1992; Dolan and others, 1991; Douglas and others, 1998; Galgano and others, 1998). Additionally, the National Research Council (1990) recommended the use of historical shoreline analysis in the absence of a widely accepted model of shoreline change.

A principal purpose of the USGS shoreline change research is to develop a common methodology so that shoreline change analyses for the continental U.S., portions of Hawaii, and Alaska can be updated periodically in a consistent and systematic manner. The primary objectives of this study were to (1) develop and implement improved methods of assessing and monitoring shoreline movement, and (2) improve current understanding of the processes controlling shoreline movement.

${ }^{1}$ University of Hawaii.

${ }^{2}$ U.S. Geological Survey Pacific Coastal \& Marine Science Center.
Achieving these ongoing long-term objectives requires research that (1) examines the original sources of shoreline data (for example, maps, air photos, global positioning system (GPS), Light Detection and Ranging (lidar)); (2) evaluates the utility of different shoreline proxies (for example, geomorphic feature, water mark, tidal datum, elevation), including the errors associated with each; (3) investigates bias and potential errors associated with integrating different shoreline proxies from different sources; (4) develops standard, uniform methods of shoreline change analysis; (5) examines the effects of human activities on shoreline movement and rates of change; and (6) investigates alternative mathematical methods for calculating historical rates of change and uncertainties associated with them.

This report summarizes historical shoreline changes on the three most densely populated islands of the eight main Hawaiian Islands: Kauai, Oahu, and Maui. The report emphasizes the hazard from "chronic" (decades to centuries) erosion at regional scales and strives to relate this hazard to the body of knowledge regarding coastal geology of Hawaii because of its potential impact on natural resources, the economy, and society. Results are organized by coastal regions (island side) and sub-regions (common littoral characteristics). This report of Hawaii coasts is part of a series of reports that include text summarizing methods, results, and implications of the results. In addition, geographic information system (GIS) data used in the analyses are made available for download (Romine and others, 2012). The rates of shoreline change and products presented in this report are not intended for site-specific analysis of shoreline movement, nor are they intended to replace any official source of shoreline change information identified by local or State government agencies, or other Federal entities that are used for regulatory purposes.

Rates of shoreline change presented herein may differ from other published rates, and differences do not necessarily indicate that the other rates are inaccurate. Some discrepancies are to be expected, considering the many possible ways of determining shoreline positions and rates of change, and the inherent uncertainty in calculating these rates. Rates of shoreline change presented in this report represent shoreline movement under past conditions and are not intended for use in predicting future shoreline positions or future rates of shoreline change. 


\section{The Role of State and Federal Governments}

One reason for conducting this national assessment of shoreline change is that there is no widely accepted, standardized method of analyzing shoreline change. Each state has its own data needs and coastal-zone management responsibilities (for example, construction set-back lines, dune protection zones, and public access) and, therefore, each state uses a different technique and standard to compile shorelines and calculate rates of shoreline movement. Consequently, calculated rates of shoreline change and projected erosion hazard zones are inconsistent from state to state and often cannot be compared directly. These inconsistencies were clearly demonstrated by the FEMA-sponsored erosion studies (Crowell and Leatherman, 1999) that were used as the basis for evaluating erosion hazards (The H. John Heinz III Center for Science, Economics, and the Environment, 2000).

Several Federal agencies (U.S. Geological Survey, USGS; Federal Emergency Management Agency, FEMA; National Oceanic and Atmospheric Administration, NOAA; and U.S. Army Corps of Engineers, USACE) have regulatory or administrative responsibilities pertaining to shorelines. These responsibilities are different, however, and require different approaches. They also offer substantial opportunities for cooperation. For example, the USACE is authorized and funded by Congress to report on the economic and environmental implications of shoreline change and the costs of erosion mitigation. Its National Shoreline Management Study (Stauble and Brumbaugh, 2003) is being conducted using existing shoreline data. The USGS shares data and information, such as the lidar-derived shoreline and rates of change, in support of that effort. NOAA has a mandate to establish the official shoreline boundary for the nation using tidal datums. Its emphasis is on safe navigation and using the shoreline to generate nautical charts. NOAA also conducts the VDatum program, which assists agencies in delineating shorelines for a variety of purposes. Congress authorized and funded FEMA to report on the economic impact of erosion hazards on coastal communities, and on claims to the National Flood Insurance Fund. To accomplish this goal, FEMA contracted with state agencies and academic researchers to conduct a pilot study of erosion hazards that included shoreline change data for limited geographic areas (Coyne and others, 1999). The USGS is responsible for conducting research pertaining to coastal change hazards, understanding the processes that cause coastal change, and developing models to predict future change. The USGS is the only government agency that has a dedicated program to monitor coastal change into the future using consistent methods nationwide. This program is critically important for the assessment of national issues such as the coastal impacts of sea-level rise.

\section{Prior National and Hawaii Shoreline Assessments}

The U.S. Army Corps of Engineers (1971) conducted the first national assessment of coastal erosion. That study identified areas of critical and non-critical erosion on the basis of economic development and potential for property loss, but rates of shoreline movement were not evaluated. Dolan and others (1985) conducted a comprehensive analysis of shoreline change for the mainland U.S. Their analysis was based on compilation of rates of shoreline change contributed by other investigators and derived from their own studies. Rates of change were presented and long-term trends of erosion and accretion were summarized.

In the State of Hawaii, process-oriented research exploring the dynamic and unique nature of Hawaiian beach morphology was first conducted by Moberly (1963). Hwang (1981) published a methodology incorporating aerial photographs to determine vegetation-line position changes since 1928 for the island of Oahu. That methodology was continued by Makai Ocean Engineering and Sea Engineering (1991), who expanded it to neighboring islands and updated the database to include aerial photography up to 1988. Sea Engineering (1988) completed a shoreline-change study of Oahu for the City and County of Honolulu based on updates to Hwang (1981). With this report, the University of Hawaii updated the database for the islands of Kauai, Oahu, and Maui with aerial photography from 2005, 2006, 2007, and 2008. This study also augmented past studies with additional photographs and maps of historical shorelines.

The County of Maui contracted with the University of Hawaii to develop a methodology for a parcel resolution (20-meter (m)) shoreline study of the Maui sandy shoreline. In 2005, the Maui Planning Commission incorporated the university study methodology and initial results into a revision of setback guidelines for beachfront property development. In 2003, the County of Maui contracted with the University of Hawaii to update the shoreline study with 2007 aerial photography. The City and County of Honolulu contracted with the University of Hawaii to use aerial photography to develop a database of shoreline change rates for sandy beaches on the island of Oahu. The County of Kauai also contracted with the University of Hawaii to conduct a similar study of all sandy beaches on the island of Kauai other than along the $\mathrm{Na}$ Pali coastline. In 2008, the Kauai County Council adopted a new setback law that included rates of coastal erosion. The university has published several reports documenting the results of its studies of shoreline change: Coyne and others (1996; 1999), Fletcher and others (1997), Fletcher and Lemmo (1999), Harney and others (2000), Rooney and Fletcher (2000; 2005), Richmond and others (2001), Norcross and others (2002; 2003), Miller and Fletcher (2003), Eversole and Fletcher (2003), Rooney and others (2003), Fletcher and others (2003), Genz and others (2007a, 2007b, 2009), Vitousek 
and others (2007), Frazer and others (2009), Romine and others (2009), and Anderson and others (2009). Additionally, the University maintains a Web site (http://www.soest.hawaii.edu/ asp/coasts/index.asp) that serves shoreline change data to the public and partnering agencies.

Since the work of Dolan and others (1985), methods of obtaining, analyzing, displaying, and storing shoreline data have improved substantially, and coastal change has continued. Furthermore, coastal scientists have not agreed on standard methods for analyzing and reporting shoreline change, nor have they identified rigorous mathematical tests that are widely accepted for quantifying the change and associated errors. Consequently, there are critical needs for (1) a nationwide compilation of reliable shoreline data, including the most recent shoreline position; and (2) an improvement in methods for obtaining and comparing shoreline positions and mathematically analyzing trends in shoreline movement.

\section{Environmental Framework of the Hawaiian Shoreline}

The Hawaii hotspot lies in the mantle under, or just south of, the "Big Island" of Hawaii where it feeds magma to two active subaerial volcanoes (Mauna Loa and Kilauea) and one active submarine volcano (Loihi). Centrally located on the Pacific plate, the hotspot is the source of the Hawaii Island Archipelago and its northern arm, the Emperor Seamount Chain (fig. 1).

The main Hawaiian Islands are built of shield volcanoes composed of basaltic lavas, intrusive dike complexes, and tephra deposits. Valley floors between volcanoes and coastal plains surrounding them consist of alluvial sediments eroded from the interior and carbonate deposits around the shoreline. The geology of most coastlines in Hawaii is characterized by outcropping volcanic bedrock, lithified tephra, and carbonate deposits (eolianite, beach rock, unconsolidated carbonate sand, and reef rock). Unconsolidated calcareous and clastic sediment, eroded from either the offshore reef or upland sources or directly produced by calcareous marine organisms, collects along the shore to form narrow beaches relative to continental siliciclastic beaches.

\section{Carbonate Geology}

Because Hawaii's white sand beaches are derived from fringing reefs, beach origin and history are intimately connected to the geologic framework of reefs. The fossil reefs of Oahu have been the subject of several studies (for example, Dollar, 1982; Grigg, 1983) that are reviewed by Fletcher and others (2008). Offshore of island beaches, the insular shelf typically dips gently seaward to near the $-20-\mathrm{m}$ contour. There, a limestone dropoff marks the end of the shallow portion of the shelf in most places. The base of this wall is typically found at a depth near $-30 \mathrm{~m}$, where a deeper, partially sand-covered terrace extends seaward to approximately $-50 \mathrm{~m}$. Below $-50 \mathrm{~m}$, a second wall and third terrace are found (Fletcher and Sherman, 1995).

The past half-million years of geologic history has been characterized by the occurrence of dramatic swings in global climate approximately every 100,000 years. Oscillating between cold episodes (glacial periods, or ice ages) and warm intervals (interglacial periods), climate changes have caused global sea level to rise and fall over a range of approximately $130 \mathrm{~m}$. During interglacial periods, sea level is high and reefs are constructed on the island margins. Because sea level reaches different heights in successive glacial cycles, the carbonate history of Hawaii is complex.

The insular shelf is constructed from multiple carbonate units representing reef accretion and erosion over recent glacial cycles (fig. 2). Specifically, the shallow shelf is a fossil reef complex dating from Marine Isotope Stage (MIS) 7 (about 190,000-210,000 years ago; Sherman and others, 1999; Grossman and Fletcher, 2004). The front of this shelf accreted separately during MIS 5a-d (about 80,000-110,000 years ago). Eolianites (lithified dunes) of late last interglacial (about 80,000 years ago) and Holocene (about 10,000 years ago to present) age (Fletcher and others, 2005) are found in the nearshore and coastal plain regions of most of the islands. Most modern Holocene reef accretion is limited to environments on the deeper front of the reef, where wave energy is not destructive. Grossman and Fletcher (2004), Conger and others (2006a), and Bochicchio and others (2009) infer that rugosity in depths less than $10 \mathrm{~m}$ atop the fringing reef is largely the result of karstification of limestone, not reef accretion, during times of lower sea level, most recently since the last interglacial period. Modern wave scour has prevented accretion in this zone. At depths greater than $10 \mathrm{~m}$, the karst surface may be overgrown by Holocene accretion where wave energy permits (Conger and others, 2006b).

Hawaiian reef morphology (fig. 3) exerts a strong control on shoreline sediment supply and dynamics. Dollar (1982) and Dollar and Tribble (1993) identified physical disturbance from waves as the most important factor determining the structure of Hawaiian coral reef communities. Expanding on this work, Grigg (1983) articulated the "intermediate disturbance hypothesis" and presented two models of coral community succession: (1) an undisturbed (lack of wave impact) community that reaches peak diversity as a result of recruitment followed by a reduction due to competition; and (2) a disturbed community where diversity is set back to zero in the case of a large disturbance, or diversity is ultimately increased in the case of intermediate disturbance (substrate is opened for new recruitment). In the case of geological studies, interpretation of paleocommunities and their role in sediment production must be grounded in an understanding of the roles of succession and disturbance. Therefore, community assemblage models related to wave energy are commonly developed during studies of Hawaiian reef stratigraphy (Engels and others, 2004). 


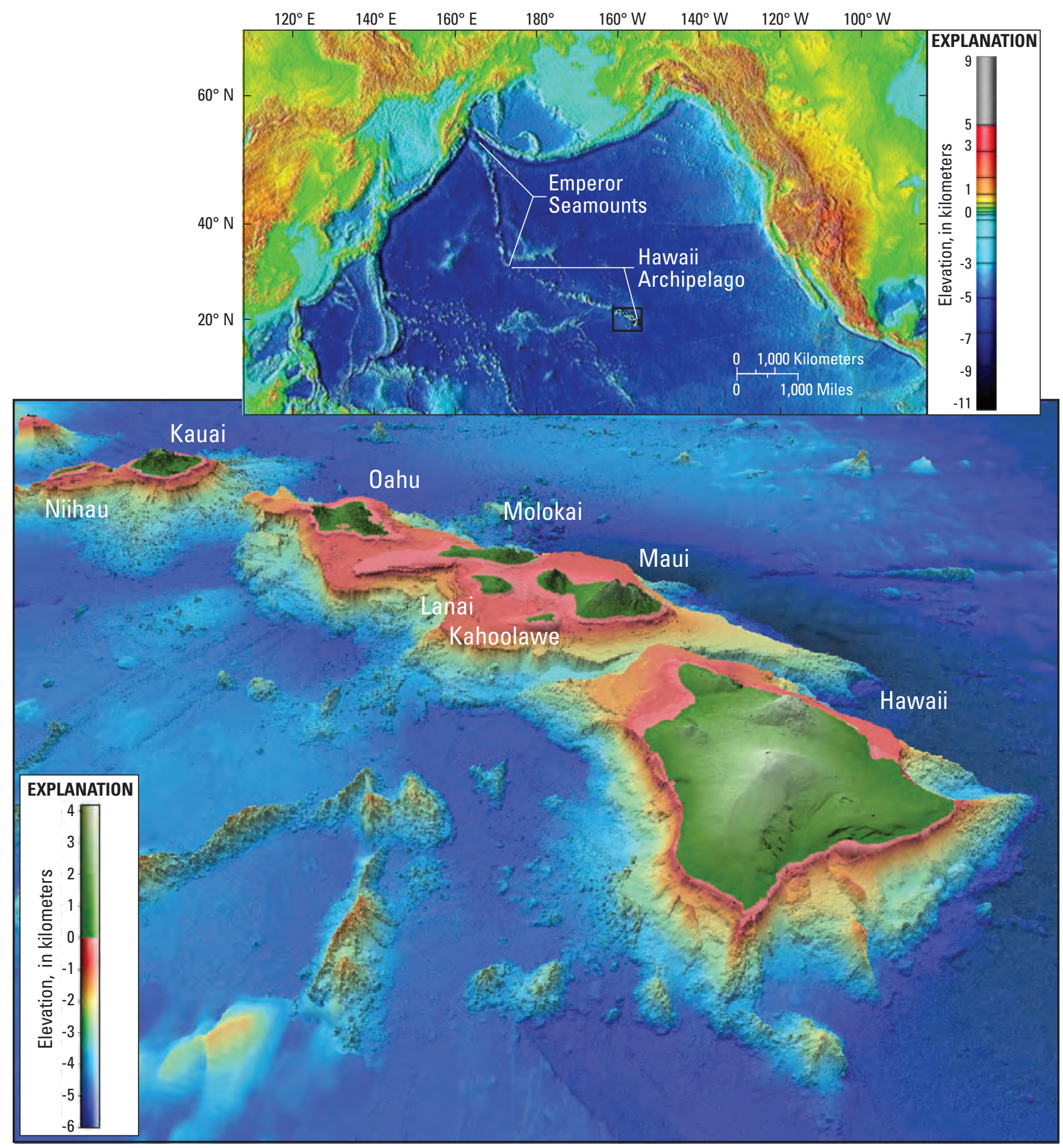

Base (top) from ETOP02v2 computer-generated global relief model

(2-minute latitude/longitude grid, Cylindrical Equidistant projection):

National Oceanic and Atmospheric Administration,

2006 (http://www.ngdc.noaa.gov/mgg/image/2minrelief.html);

(bottom) from Hawaiian multibeam bathymetry synthesis

computer-generated relief model

(version 18, 0.0005-degree latitude/longitude grid, WGS 1984),

Hawaii Mapping Research Group, 2011

(http://www.soest.hawaii.edu/HMRG/multibeam/index.php).

Figure 1. Computer-generated relief models of the Hawaii Island Archipelago and its northern arm, the Emperor Seamount Chain. 


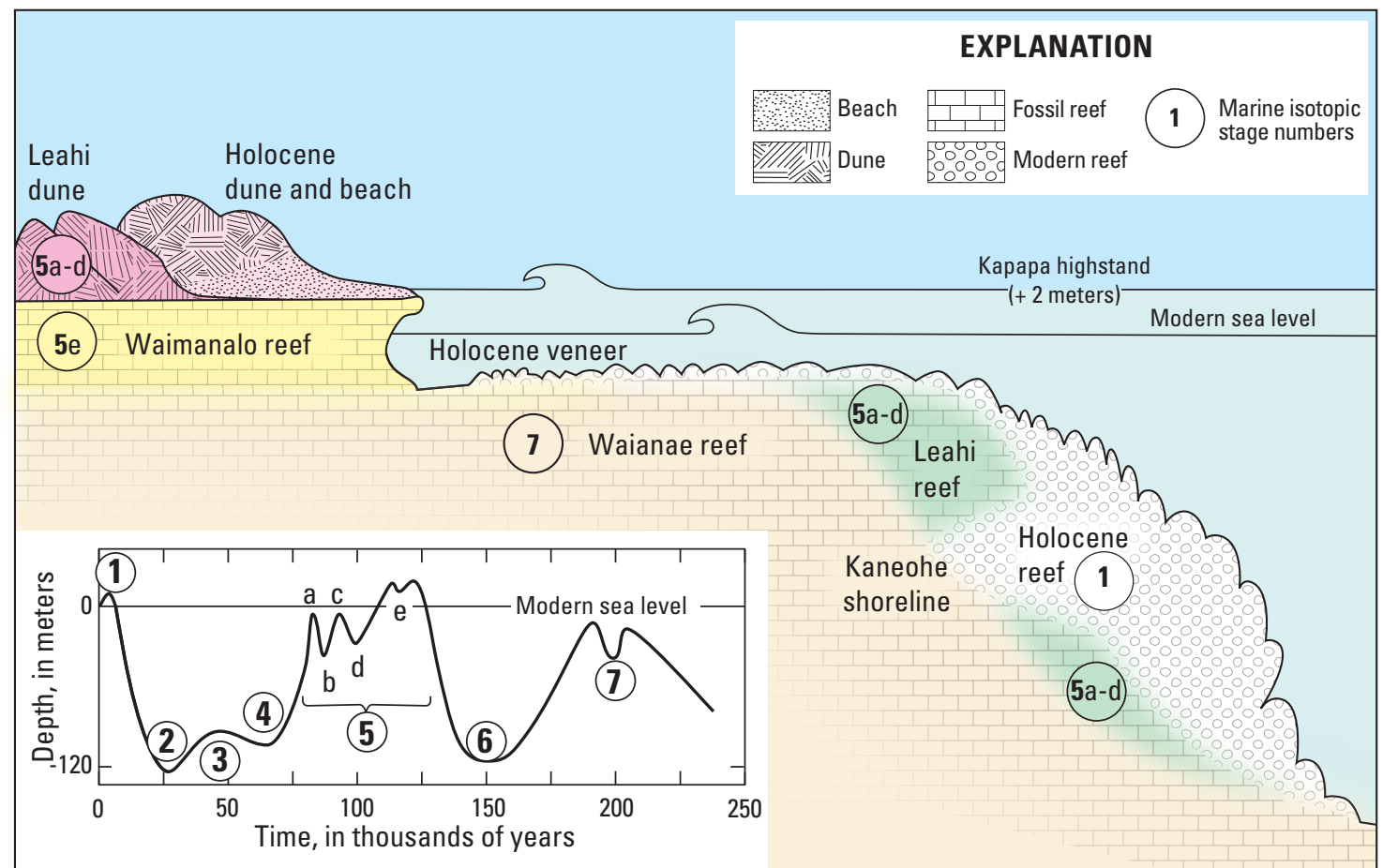

Figure 2. Principal stratigraphic components of the Oahu carbonate shelf. (Modified from Fletcher and others, 2008)

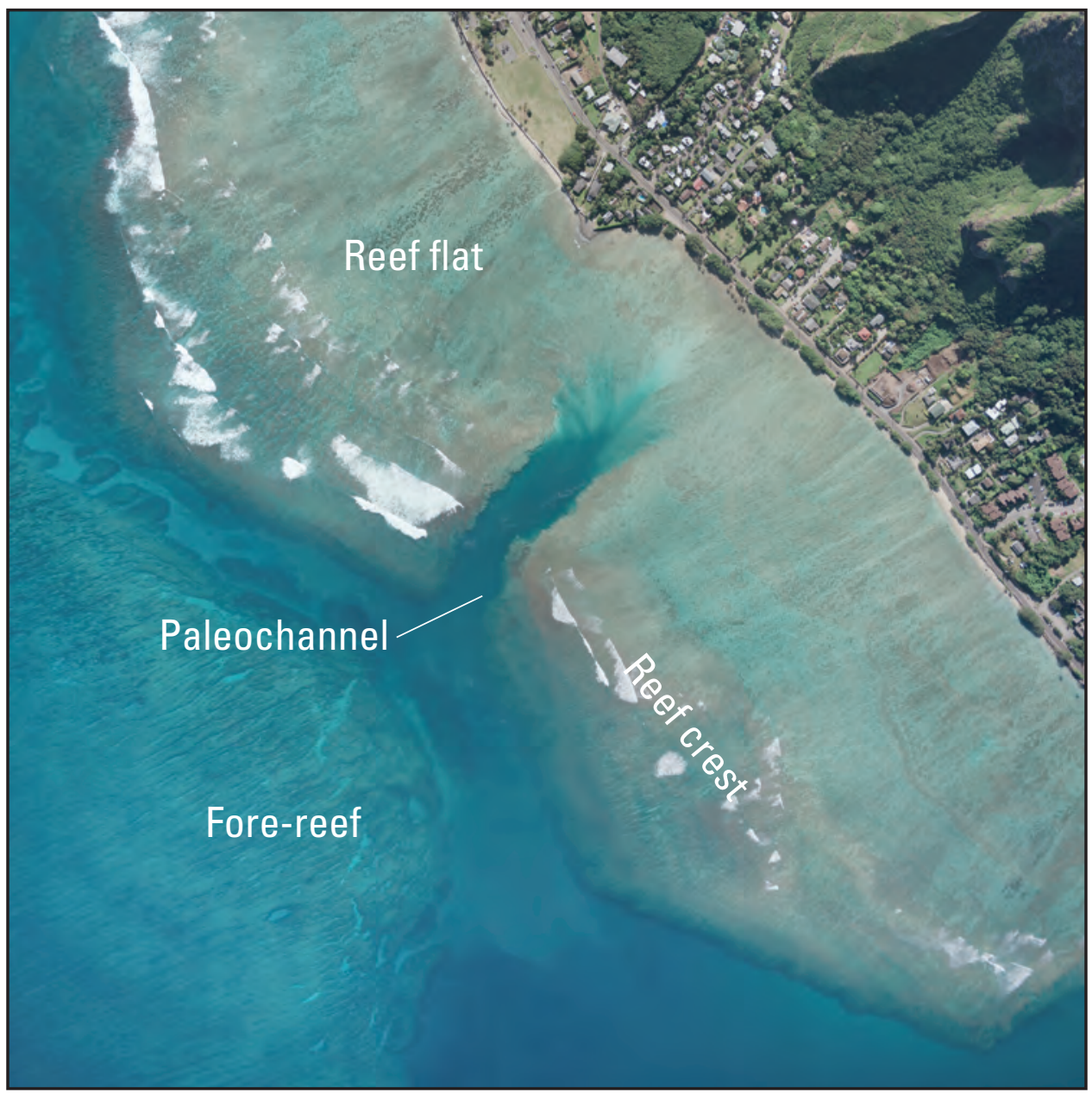

Figure 3. Carbonate sand beaches in Hawaii are the result of reef bioerosion and direct production of calcareous material by reef organisms. Reef morphology exerts strong control on shoreline sediment supply and dynamics. (Kaaawa, Oahu, location shown in figure 26) (Photograph by Hawaii Aviation, Inc., 2005) 
To improve understanding of reef community assemblage in the Hawaiian Islands, Harney and others (2000), Harney and Fletcher (2003), Grossman and Fletcher (2004), Engels and others (2004), and Grossman and others (2006) surveyed benthic communities to develop coral assemblage models marking distinct environments. In their work along the south shore of the island of Molokai, Engels and others (2004) developed a community zonation model related to wave-generated bed shear stress as modeled by Storlazzi and others (2002). Engels and others (2004) define three assemblages: low, mid, and high energy. The zonation model relates bed shear stress to percent living coral cover, relative percent coralline algae cover, dominant coral species, dominant coral morphologies, and water depth. Each assemblage is divided into three depth zones: less than $5 \mathrm{~m}, 5$ to $10 \mathrm{~m}$, and greater than $10 \mathrm{~m}$. All observed coral types that account for at least 10 percent of living coral cover are represented in the model.

Modern reef communities in wave-exposed settings are suppressed to a veneer (Grigg, 1998). North Pacific winter swell produces the largest and most frequently damaging energy, yet waves of greatest magnitude and impact are likely to occur only rarely and are associated most often with strong El Niño years (for example, 1998) perhaps a decade or more apart (Rooney and others, 2004). Intervening coral growth able to survive the strong annual pounding by waves may be wiped out by these interannual waves of extraordinary size and energy. Radiocarbon dates of fossil corals show that coral growth in wave-exposed settings has been continually suppressed since about 5,000 years ago on northern exposed coasts (Rooney and others, 2004) and about 3,000 years ago on southern shorelines (Grossman and others, 2006).

\section{Beach Sediments}

Effective, sustainable management of Hawaiian beach systems requires an understanding of sediment production, as many beaches are losing sediment with time (eroding).

Hawaiian beach sands are derived primarily from calcareous debris eroded from the insular reef shelf, which is reworked into sand-size grains by breaking waves on the reef shelf and at the shoreline. Hawaiian beach sands are, on average, medium in size (classification of Wentworth (1922)) (Inman, 1952; Dunbar and Rodger, 1957), though the sediment on individual beaches can range in size from coarse to fine sand. Moberly and Chamberlain's (1964) analysis of littoral sediment grain size around the Hawaiian Islands shows that grain size is closely related to wave and current energy, which in Hawaii is strongly related to shoreline aspect (table 1). Beach sediments on these islands generally are finest on the windward or northeastern-facing coasts as a result of the persistent working of the sediment by trade wind waves with fairly consistent heights and periods that rapidly sorts the sediment and reduces its size.

Table 1. Relation of littoral sand grain size to shoreline aspect (wind and wave exposure) in Hawaii.

[Modified from Moberly and Chamberlain, 1964; phi, phi units; mm, millimeters; --, no data]

\begin{tabular}{lccccc}
\hline \multirow{2}{*}{ Sample characteristics } & Windward & Southeastern & Leeward & Northeastern & All \\
\cline { 2 - 6 } & \multicolumn{5}{c}{ Kauai } \\
\hline Number of samples & 58 & 54 & 70 & 92 & 274 \\
Median size (phi) & 1.17 & 1.82 & 1.50 & 1.26 & 1.41 \\
Median size (mm) & 0.47 & 0.27 & 0.35 & 0.42 & 0.38 \\
\hline \multicolumn{7}{c}{ Oahu } \\
\hline Number of samples & 224 & 77 & 107 & 133 & 521 \\
Median size (phi) & 1.52 & 0.73 & 0.89 & 0.66 & 1.09 \\
Median size (mm) & 0.35 & 0.60 & 0.54 & 0.63 & 0.47 \\
\hline \multicolumn{7}{c}{ Maui } \\
Number of samples & 35 & 0 & 258 & 81 & 374 \\
Median size (phi) & 2.42 & -- & 1.79 & 1.21 & 1.72 \\
Median size (mm) & 0.18 & -- & 0.29 & 0.43 & 0.30 \\
\hline & \multicolumn{7}{c}{ All } \\
\hline Number of samples & 317 & 131 & & & \\
Median size (phi) & 1.52 & 1.28 & 1.50 & 1.21 & 1.41 \\
Median size (mm) & 0.35 & 0.44 & 0.35 & 0.43 & 0.38 \\
\hline
\end{tabular}


Sediments on south shore beaches tend to be coarse and poorly sorted, as runoff from strong but infrequent southerly "Kona" storms washes coastal plain sediments back into the littoral system and high wave energy fragments the nearshore reef. These high-energy wave conditions are short lived so that new sediments are not highly abraded or sorted. Strong surf generated on western and northern coasts by winter North Pacific swell leads to coarse-grained beaches, as sediments are abraded only during a portion of the year. In general, the grain-size diameter of sand on all beaches tends to be finer in the summer months (June to September) and coarser in the winter months (November to March).

Beach and reef morphology is similarly dependent on shoreline aspect (Moberly and Chamberlain, 1964; Grigg, 1998). Beaches on north- and west-facing shorelines tend to be the longest and widest, whereas reefs tend to be narrower, deeper, and more irregular. North- and west-facing beaches transition from wide and gently sloping in summer to steep and narrow in winter, as sand is moved seaward.

Lacking a continental source, sand in the Hawaiian Islands is often highly calcareous with a smaller contribution from eroded volcanic rock. The volcanic component of beach sediments is typically controlled by the bedrock geology adjacent to the shoreline (Stearns and Vaksvik, 1935; Macdonald and others, 1960). The light color of most Hawaiian beaches results from the dominance of grains from fragmented marine invertebrate animals and algae. Moberly and Chamberlain (1964) show that the composition of many Hawaiian beaches is dominated by larger (approaching $1 \mathrm{~mm}$ in diameter) species of foraminifera (27 percent, 80 percent of which was Amphistegina), followed by mollusks, red algae, and echinoids. Coral fragments constitute only the fifth largest fraction. Halimeda, sponge spicules, crab fragments, and similar rare components are less abundant. The predominance of foraminifera in beach sand is thought to result more from their relative durability in wave action rather than from their ecological abundance (Moberly, 1968).

In contrast to the island-wide surveys of beach sands mentioned above, Harney and others (2000) performed a more detailed study of sand composition in Kailua Bay, windward Oahu (beach face to a depth of $-20 \mathrm{~m}$ ). They found that more than 90 percent of sand grains were biogenic carbonate dominated by skeletal fragments of coralline algae (for example, Porolithon - up to 50 percent) followed by the calcareous green algae Halimeda, coral fragments, mollusk fragments, and benthic foraminifera. Results of this work indicate that sand composition and age can vary considerably across the sea floor. These results also indicate a relatively low percentage of foraminifera in benthic sands, whereas Moberly and Chamberlain (1964) show substantially higher percentages in beach sand.

Radiocarbon age of carbonate sands has been used as an indicator of longevity, production rate, and transport of coastal sediments (Kench, 1997; Gischler and Lomando, 1999). Dates measured for Hawaiian coral and skeletal fragments show that sediment is produced, transported, and lost from the coastal system on a millennial scale. Dates measured for
Kailua beach and offshore sediment bodies range from 500 to 2,000 years before present (BP) (Harney and others, 2000). Similarly, radiocarbon dates for Amphistegina in surface beach sands of Oahu show ages of more than 1,500 years (Resig, 2004). The dominance of older sediment grains may reflect changes in carbonate productivity during the Holocene Epoch. As an example, Kailua's broad, flat coastal plain was flooded during a +1 to $2-\mathrm{m}$, mid- to late Holocene sea level high stand (Stearns, 1935; Fletcher and Jones, 1996; Grossman and Fletcher, 1998). A substantial portion of sediment volume in Hawaiian beaches could result from a past period of higher productivity related to higher sea levels (Calhoun and Fletcher, 1996; Harney and others, 2000) if such an expanded shallow nearshore environment resulted in a proliferation of calcareous algae and their detritus (Kraft, 1982; Athens and Ward, 1991).

Sediment storage in Hawaiian beach systems occurs as either beach reservoirs or nearshore bodies of sediment. Beach reservoirs in the Hawaiian Islands are low relative to those in continental settings. According to the most comprehensive study of Hawaiian beach volume, (Moberly and Chamberlain, 1964), a total of $39.56 \times 10^{6} \mathrm{~m}^{3}$ (cubic meters) of sand was stored in beaches as of 1964. More than one-third of all beach sand in the Hawaiian Islands is found on the beaches of Kauai and more than one-fourth is found on the beaches of Oahu. The two islands together hold 61.4 percent of the total beach sand found in the State of Hawaii.

Nearshore sediment reservoirs have gained considerable attention from researchers as they may contain sands that may still be part of the active sand exchange system. A comparison of beach volume and reef-top sediment volume in Kailua Bay showed that more than $10^{6} \mathrm{~m}^{3}$ of sediment is stored in the nearshore sand bodies other than the beach (Bochicchio and others, 2009).

Reef karstification is an important aspect of sediment storage in sediment budgets for Hawaii (Conger, 2005; Bochicchio and others, 2009). Unconsolidated sediment accumulates on the reef surface either by erosion of reef framework or by direct production as skeletal components (Harney and Fletcher, 2003). In many cases this sediment fills reef-top depressions, creating discrete, isolated sediment deposits. Sediment deposits on reef flats are conspicuous and display large variations in size, shape, and location, but are easily recognized in remotely sensed imagery (Conger and others, 2006). Sediment deposits also represent a prominent component of the geologic framework of insular shelves and potentially are an active component of littoral sediment budgets. Sediment exchange between sand deposits and the beach face could be an important component of shoreline stability and in some cases could provide substantial quantities of affordable sand for beach replenishment (Moberly and Chamberlain, 1964; Casciano and Palmer, 1969; Moberly and others, 1975). Most reef-top sand bodies are in water less than $10 \mathrm{~m}$ deep (Conger, 2005). Detailed volume analysis of sand bodies in Kailua Bay, windward Oahu, shows a similar relation of sediment volume to depth if the contribution from large sand channels is excluded (fig. 4) (Bochicchio and others, 2009). 


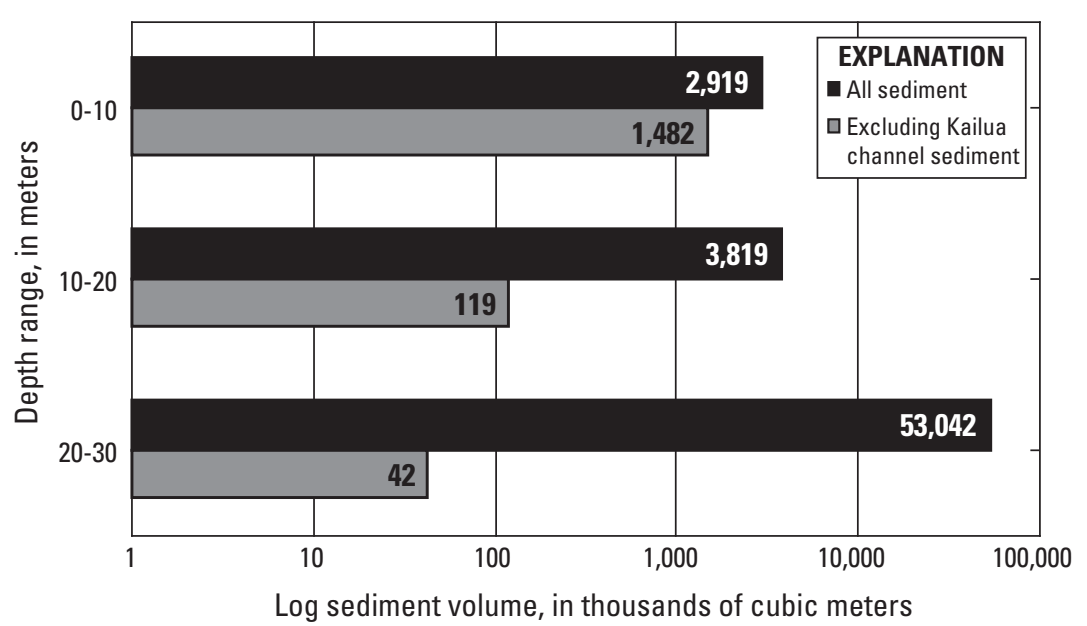

Figure 4. Volume of sediment by depth zone in Kailua Bay, Oahu. (Location shown in figure 26) (Modified from Bochicchio and others, 2009)
Sediment trapping on the reef surface keeps sand potentially available for circulation within a littoral cell rather than allowing it to be lost to offshore sites (Grossman and others, 2006). Most sediment in reef systems is produced on the shallow nearshore platform, where carbonate productivity and erosion are highest. Sediment remains on the reef platform in storage or as part of the active littoral system unless it is transported seaward of the reef crest and insular shelf (Harney and Fletcher, 2003). Once sediment crosses this threshold, the comparatively steep angle of the forereef slope likely prevents most shoreward transport, effectively removing sediment from littoral circulation unless it moves back into shallow water through paleochannels cut into the reef (Grossman and others, 2006). On many islands, steep submarine terraces more than $20 \mathrm{~m}$ deep exacerbate sediment loss by presenting a seawardfacing sharp break in topography (Coulbourn and others, 1974). In some cases, large channels are incised perpendicular to the shoreline and through the reef crest, creating a potential pathway for sediment exchange between inner and outer portions of the reef platform (Grossman and others, 2006).

The majority of reef-top depressions are relict features incised into the surface of Hawaiian reef platforms through dissolution or fluvial erosion during periods of lower sea level, when subaerially exposed limestone is in contact with meteoric waters (Purdy, 1974). The resulting channel and doline karst landscape is drowned by rising sea level and subsequently filled with sediment, unless depressions are filled by new reef accretion (Grigg, 1998; Grossman and Fletcher, 2004; Rooney and others, 2004; Conger, 2005; Grossman and others, 2006). Most shallow reef-top sediment storage (deposition) occurs in depressions (fig. 5) that likely are eroded during periodic subaerial exposures of fossilized reefal limestone. Therefore, the potential for modern sediment storage is, to some degree, a function of pre-Holocene erosion (increasing storage space) and post-Holocene reef accretion infilling the eroded features (reducing storage space).
A study of sediment-body distribution on the reef of southeastern Oahu (Bochicchio and others, 2009) indicates that two factors control the pre-Holocene karst and fluvial erosion that formed the reef-top depressions: (1) availability of freshwater drainage and (2) topographic slope of the reef. Meteoric runoff from onshore watersheds is a major contributor to erosion of the exposed limestone reef. It follows that proximity to an onshore watershed is a major control on depression formation and, consequently, offshore sand storage. Similarly, complexes of sand bodies are observed more commonly on low reef slopes than high on the southeast Oahu reef (Bochicchio and others, 2009).

\section{Sea Level}

Local relative sea level around Hawaii (fig. 6) is not only dependent on the global eustatic average trend (a rise of about $3 \mathrm{~mm} / \mathrm{yr}$ (millimeters per year); Merrifield and others, 2009) but also is affected by local oceanographic patterns, basin-scale meteorology, and localized flexure of the oceanic lithosphere, which responds elastically to the heavy load of volcanic rocks over the Hawaiian hotspot. It is estimated that one half of the upward construction of Hawaiian volcanoes is lost to subsidence and that most of the volcanoes have subsided 2 to 4 kilometers $(\mathrm{km})$ since emerging above sea level (Moore, 1987). Subsidence associated with active volcanism causes upward plate flexure at a radius that correlates to the modern-day position of Oahu. Oahu, as evidenced by the presence of emerged fossil reefs, is undergoing long-term geologic uplift; however, the rate of uplift is less than 1 percent of the rate of sea-level rise.

Sea level has risen around Hawaii approximately $1.5 \mathrm{~mm} / \mathrm{yr}$ over the past century. Although this rate may seem small, long-term sea-level rise can lead to chronic coastal erosion, coastal flooding, and drainage problems, all of which 


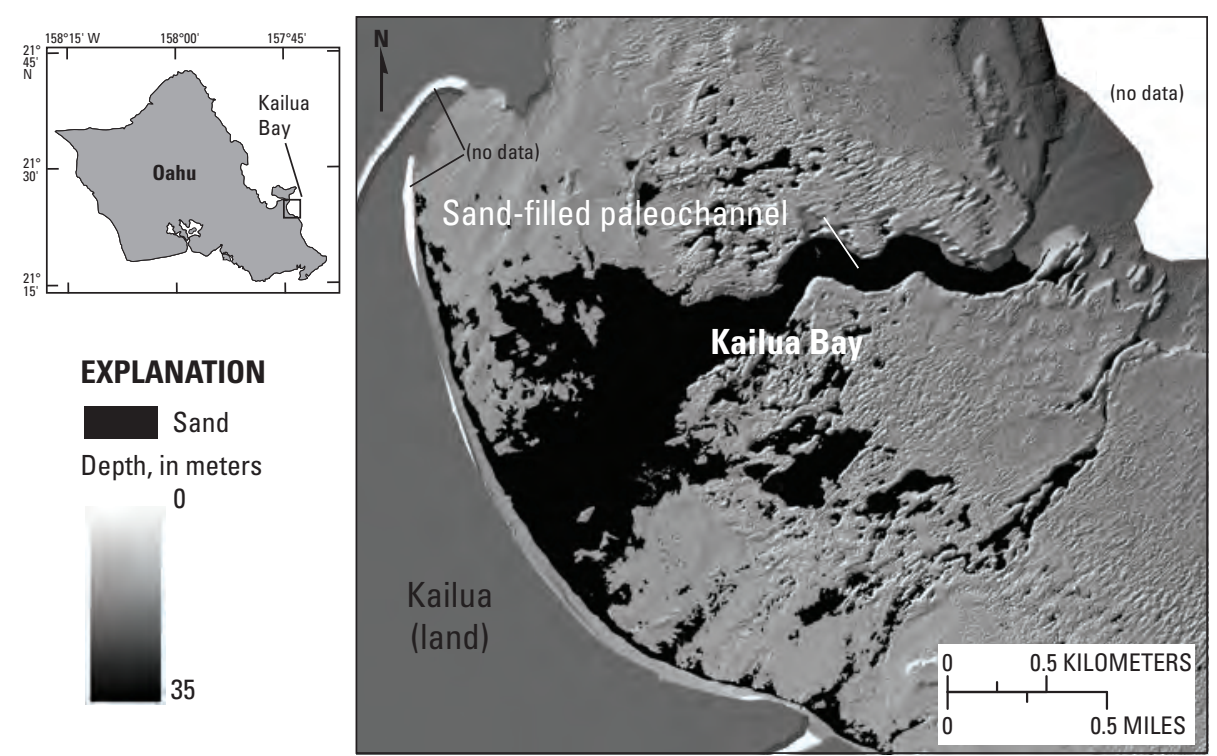

Figure 5. Computer-generated relief model of Kailua Bay, Oahu. Sand bodies on the sea floor are shown in black. (Modified from Conger and others, 2009) are experienced in Hawaii. This long-term trend also increases the impact of short-term fluctuations when extreme tides cause episodic flooding and erosion along the coast (Firing and Merrifield, 2004; Fletcher and others, 2010).

Coastal erosion, although not solely tied to climate change, is an important factor in managing the problem of rising sea level. Sea-level rise accelerates and expands erosion, potentially affecting beaches that previously were stable. Chronic erosion seaward of developed lands has historically led to seawall construction, resulting in beach loss (Fletcher and others, 1997).

Although the rate of global mean sea-level rise has approximately doubled since 1990, sea level not only did not rise everywhere, but actually declined in some large areas (National Aeronautics and Space Administration, 2011). The pattern of global sea-level change is complex because sea level is affected by winds and ocean currents, which also are changing. In Hawaii, improving our understanding of the effects of sea-level change requires attention to local variability with careful monitoring and improved modeling efforts. Climate change is expected to cause sea-level rise to continue, and accelerate, for several centuries; and may exceed $1 \mathrm{~m}$ above the 1990 level by the end of the 21st century (Fletcher, 2009b; Vermeer and Rahmstorf, 2009). Continued sea-level rise will increase marine inundation of coastal roads and communities. Saltwater intrusion will intensify in coastal wetlands, groundwater systems, estuaries, and elsewhere. Extreme tides already (2012) cause drainage problems in developed areas.

Sea-level rise threatens Hawaiian beaches (fig. 7), tourism, quality of life, and infrastructure. Hawaiian communities located at the intersection of intensifying storm runoff and rising ocean waters will likely experience increased flooding.

\section{Waves}

The four dominant regimes responsible for large swells in Hawaii are the North Pacific swell, trade wind swell, southern swell, and Kona storm waves (including hurricanes). The regions of influence of these regimes, outlined by Moberly and Chamberlain (1964), are shown in figure 8. A rose diagram depicting annual swell heights and directions (Vitousek and Fletcher, 2008) has been added to the original illustration. The average directional wave spectrum in Hawaiian waters is bimodal and is dominated by the North Pacific and trade wind swell regimes (Aucan, 2006). Although important to describe the complete Hawaiian wave climate, southern swell and Kona storm regimes do not occur with the high magnitude and frequency that characterize North Pacific and trade wind swell regimes. The buoy network around Hawaii is managed by the NOAA National Data Buoy Center (NDBC) (fig. 8). These sensors provide the local wave-climate data. Buoy reports are available at http://www.ndbc.noaa.gov/maps/Hawaii.shtml.

Interannual and decadal cycles, including El Niño Southern Oscillation (ENSO; Goddard and Graham, 1997) and Pacific Decadal Oscillation (PDO; Mantua and others, 1997; Zhang and others, 1997), are important contributors to the variability of the Hawaiian wave climate. These largescale oceanic and atmospheric phenomena are thought to control the number and extent of extreme swell events; for example, strong ENSO events are thought to increase the size and frequency of swell events, relative to non-ENSO years (Seymour and others, 1984; Caldwell, 1992; Seymour, 1998; Allan and Komar, 2000; Graham and Diaz, 2001; Wang and Swail, 2001; Aucan, 2006). The magnitude and frequency of extreme wave events may control processes 
A. Hilo, Hawaii $3.27+/-0.35$ millimeters per year

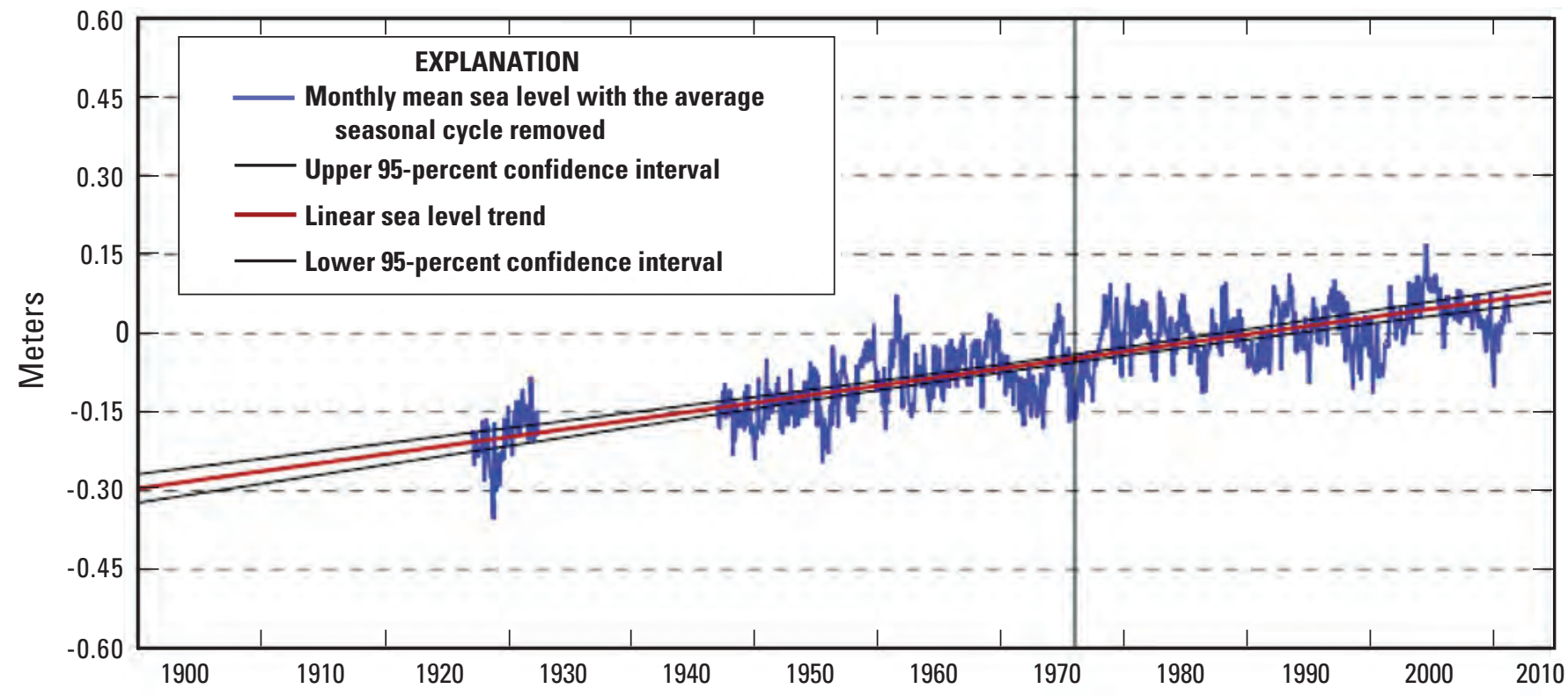

B. Kahului, Hawaii $2.32+/-0.53$ millimeters per year

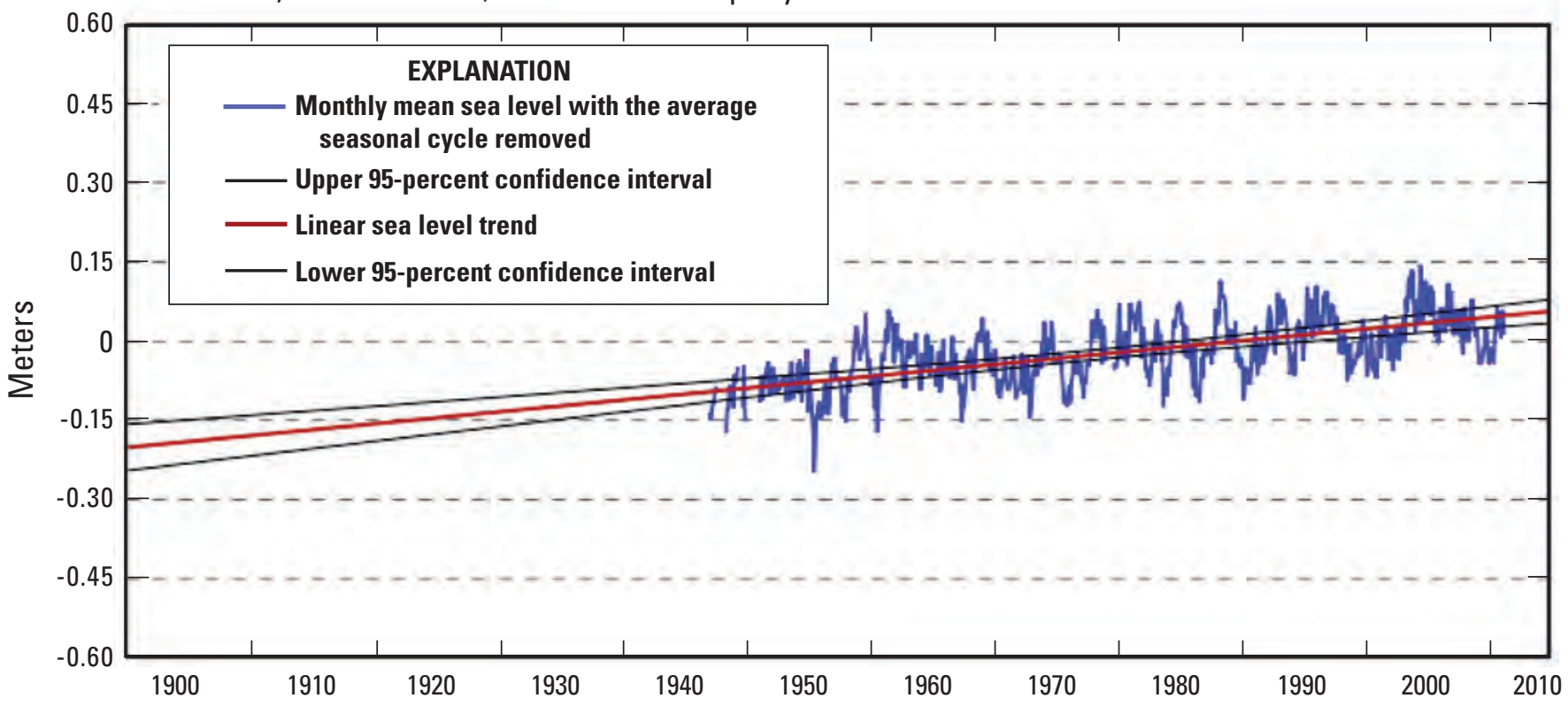

Figure 6. Mean-sea-level trends at A, Hilo, 1927-2010; B, Kahului 1947-2010; C, Honolulu 1905-2010; and D, Nawiliwili, 1955-2010, Hawaii. (Data from National Oceanic and Atmospheric Administration, 2011) 
C. Honolulu, Hawaii $1.50+/-0.25$ millimeters per year

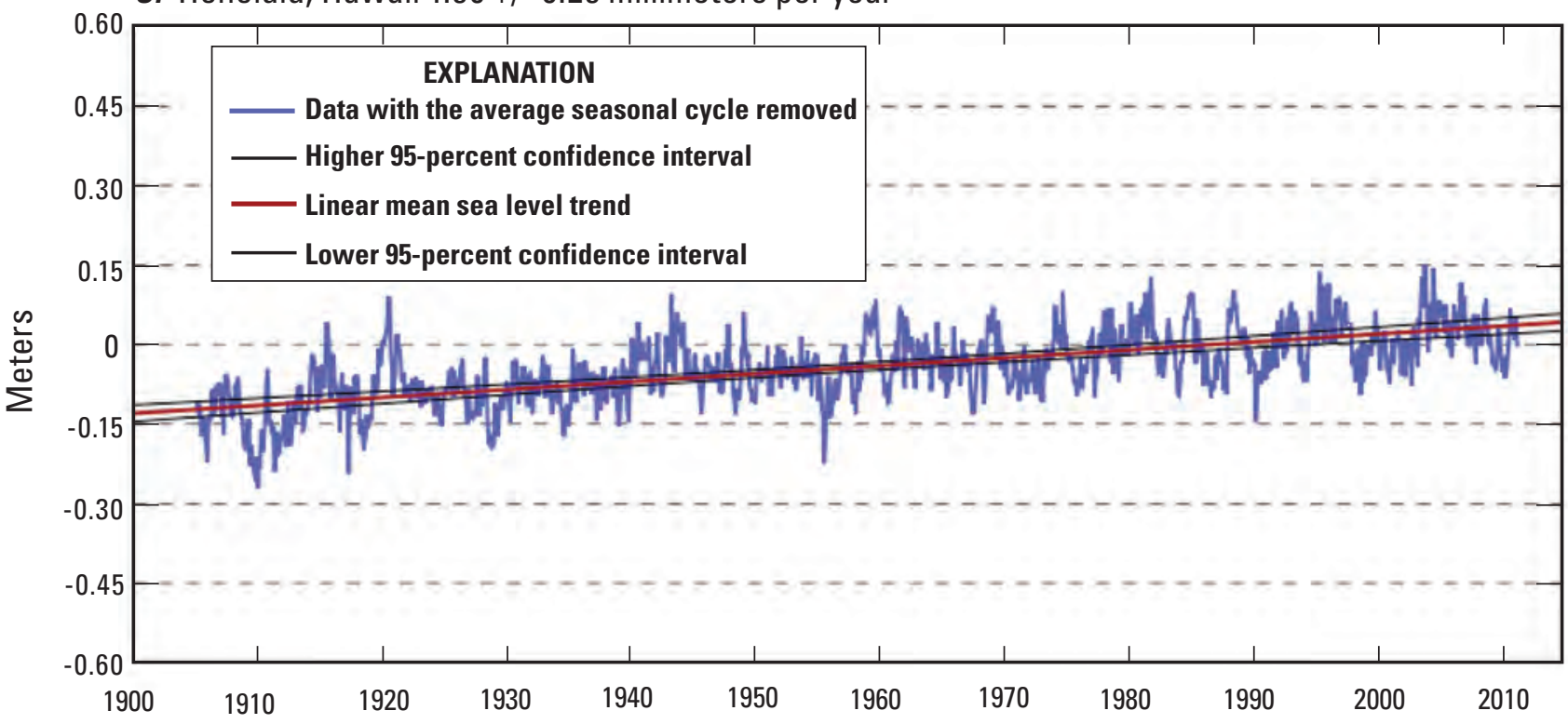

D. Nawiliwili, Hawaii $1.53+/-0.59$ millimeters per year

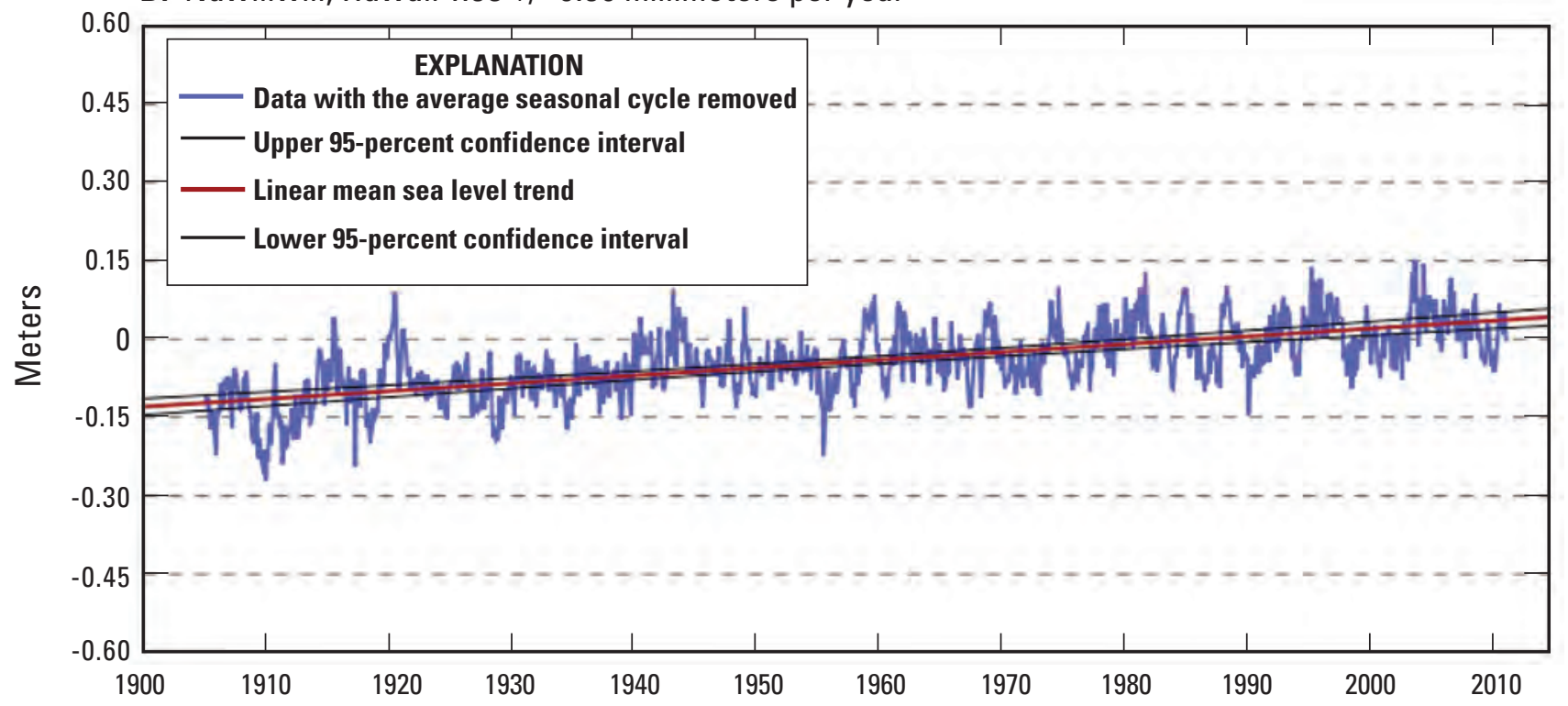

Figure 6. - Continued 


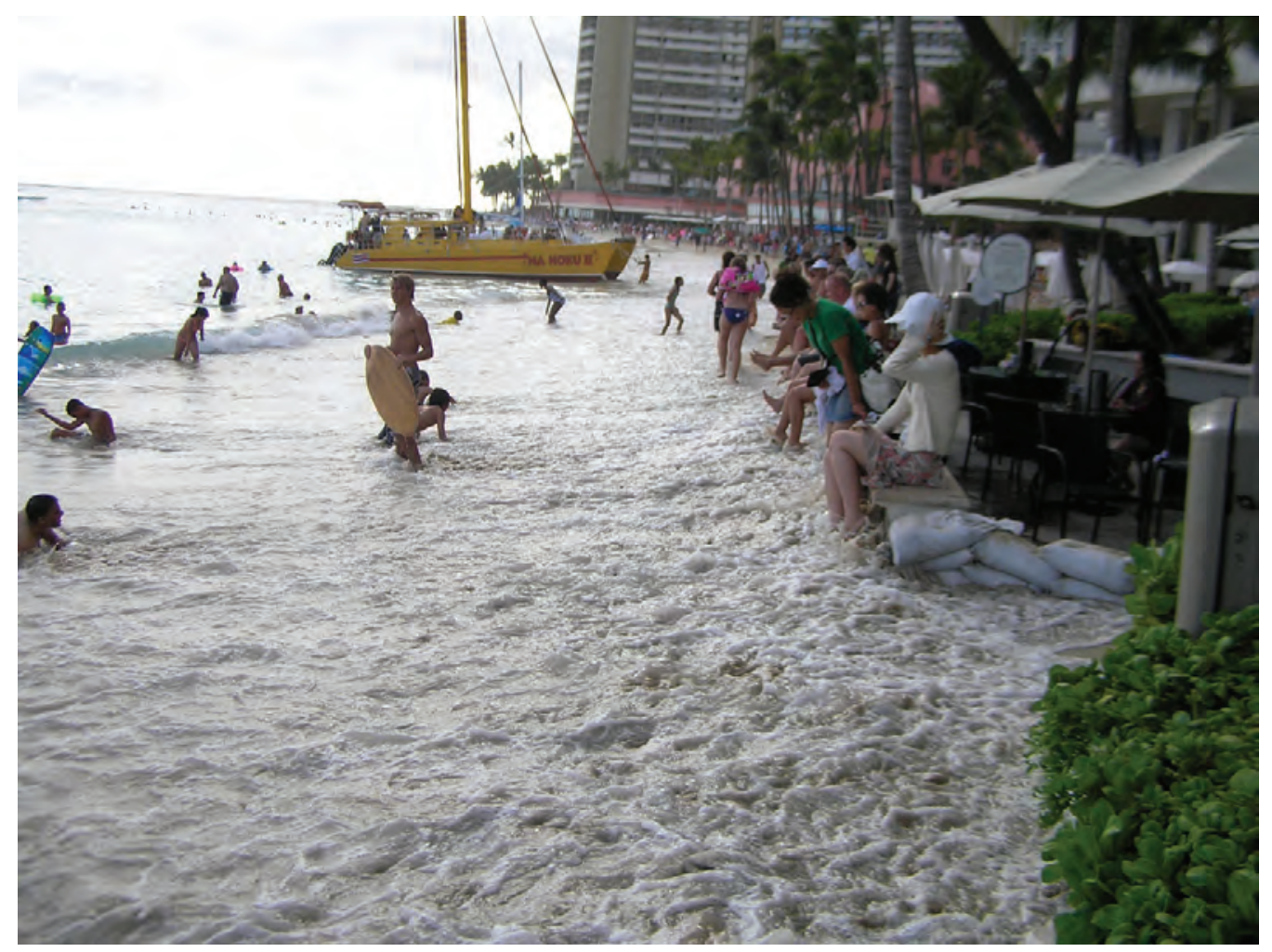

Figure 7. The narrow beach at Waikiki is threatened by erosion (Waikiki, Oahu; location shown in figure 29). Because the groundwater table rises and falls with sea level, drainage problems likely will become a major problem in this and other coastal communities. (Photograph by C.L. Conger, University of Hawaii Sea Grant College Program)

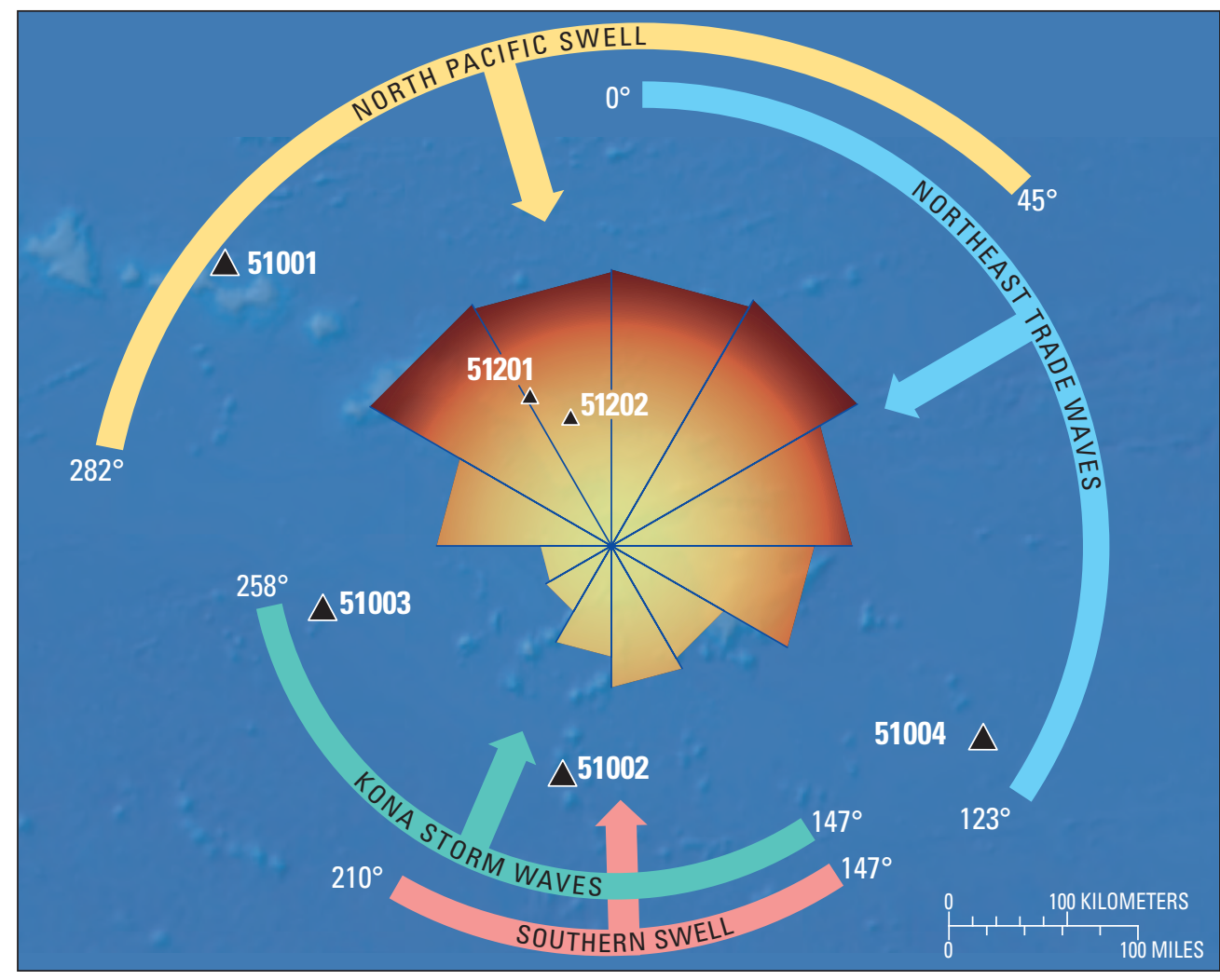

\section{EXPLANATION}

Annual significant wave height, in meters

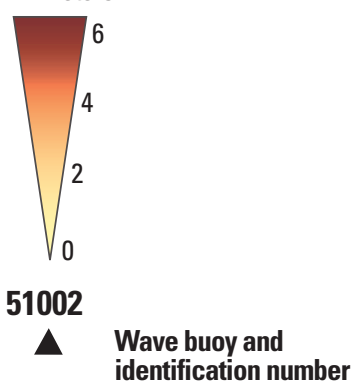

From Vitousek and Fletcher, 2008

Figure 8. Dominant swell regimes and wave-monitoring buoy locations in Hawaii. (Modified from Moberly and Chamberlain, 1964, and Vitousek and Fletcher, 2008). 
such as coral development (Dollar and Tribble, 1993; Rooney and others, 2004) and beach morphology changes in Hawaii and elsewhere (Moberly and Chamberlain, 1964; Ruggiero and others, 1997; Kaminsky and others, 1998; Storlazzi and Griggs, 2000; Rooney and Fletcher, 2005; Ruggiero and others, 2005).

Located in the middle of the large swell-generating basin of the North Pacific, Hawaii receives large ocean swell from extratropical storms that track predominantly eastward from origins in the Northwest Pacific. The storminess of the North Pacific reaches a peak in the boreal winter, as the Aleutian low intensifies and the North Pacific high moves southward. Strong winds associated with these storms produce large swells, which can travel for thousands of miles until reaching the shores of Hawaii. In summer months, the North Pacific high moves northward and storms in the North Pacific become infrequent (Flament and others, 1996). Satellite-derived average wave heights over the North Pacific in winter and summer are shown in figure 9. The average winter wave heights in the North Pacific are about $3 \mathrm{~m}$ or greater, whereas summer wave heights are about $2 \mathrm{~m}$ or less. Although figure 9 gives the average state of the North Pacific, individual storm events in this dynamic system typically track eastward with wave heights on the order of 5 to $10 \mathrm{~m}$. These swell-producing storms occur during winter months with typical reoccurrence intervals of
1 to 1.5 weeks (for 5- to 7-m swells), 2 to 3 weeks (for 7- to 9-m swells), and 1 month (for swells $9 \mathrm{~m}$ high or greater). Many North Pacific storms do not produce swells that reach Hawaii. Storms that originate in high latitudes and those that track to the northeast send swells to the Aleutian Islands and the Pacific Northwest. Swells that originate from storms in lower latitudes and those that track slightly to the southeast reach Hawaii with the largest wave heights.

Hawaii receives its largest swell from the North Pacific, with an annually recurring maximum deep-water significant (average of the highest third of the waves) wave height of $7.7 \mathrm{~m}$ (Vitousek and Fletcher, 2008) with peak periods of 14 to 18 seconds. However, the size and number of swell events in Hawaii vary each year by a factor of 2 (Caldwell, 2005). The annual maximum wave height recorded at buoy 51001 (fig. 8) ranges from about $6.8 \mathrm{~m}$ (in 1994, 1997, and 2001) to $12.3 \mathrm{~m}$ (in 1988).

The seasonal cycle of North Pacific swell peaks in winter with a daily average wave height about $4 \mathrm{~m}$ (fig. 10) (Vitousek and Fletcher, 2008). Aucan (2006) depicted the monthly average directional spectra from buoy data at Waimea (buoy 51201) and Mokapu (buoy 510202) that showed the dominance of North Pacific swell out of the northwest in winter months, and relatively persistent energy out of the northeast in higher frequency bands associated with trade wind swell.

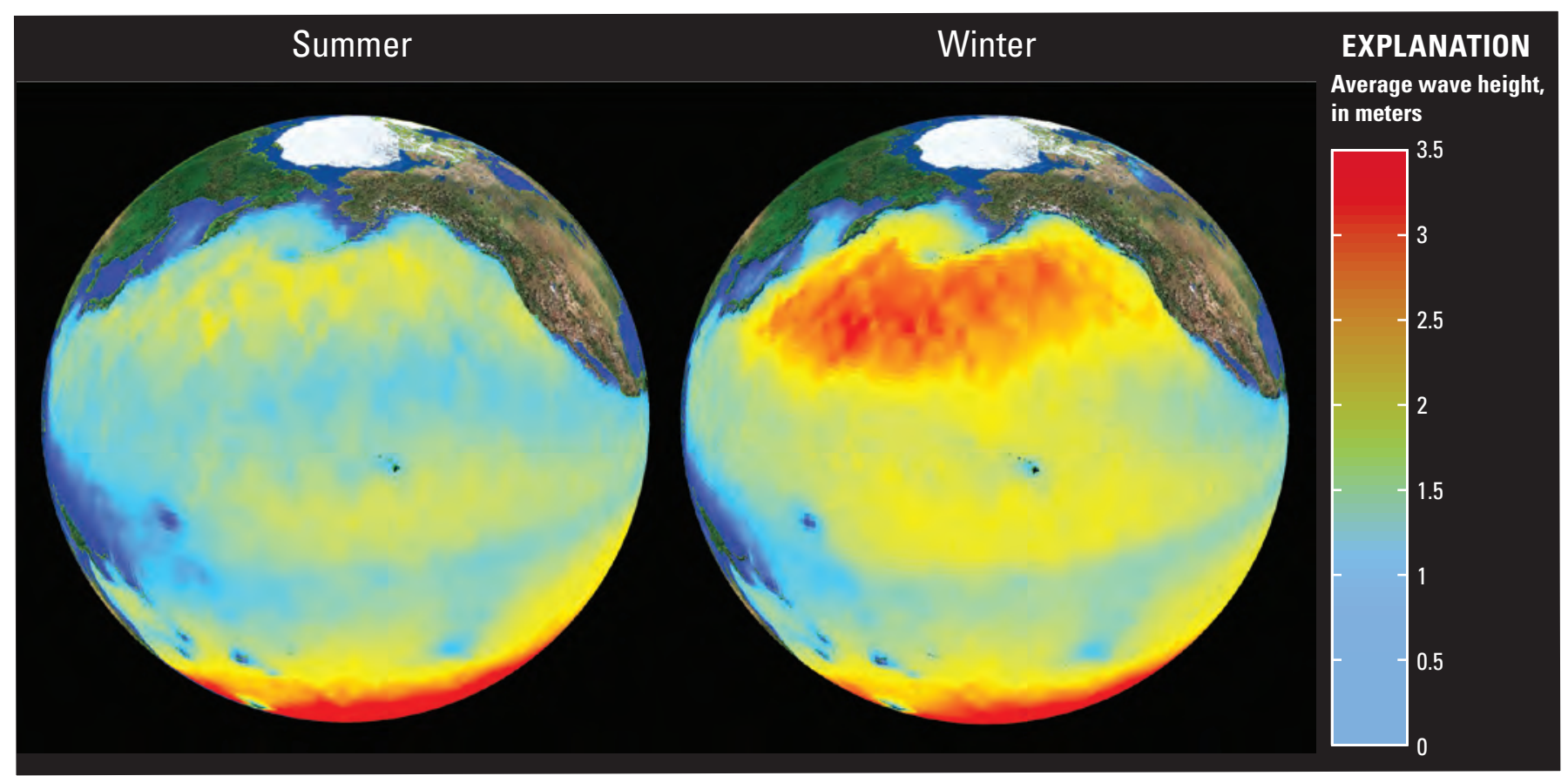

Figure 9. Satellite images (JASON-1) showing derived average wave height over the North Pacific in summer and winter. (National Oceanic and Atmospheric Administration, 2010) 


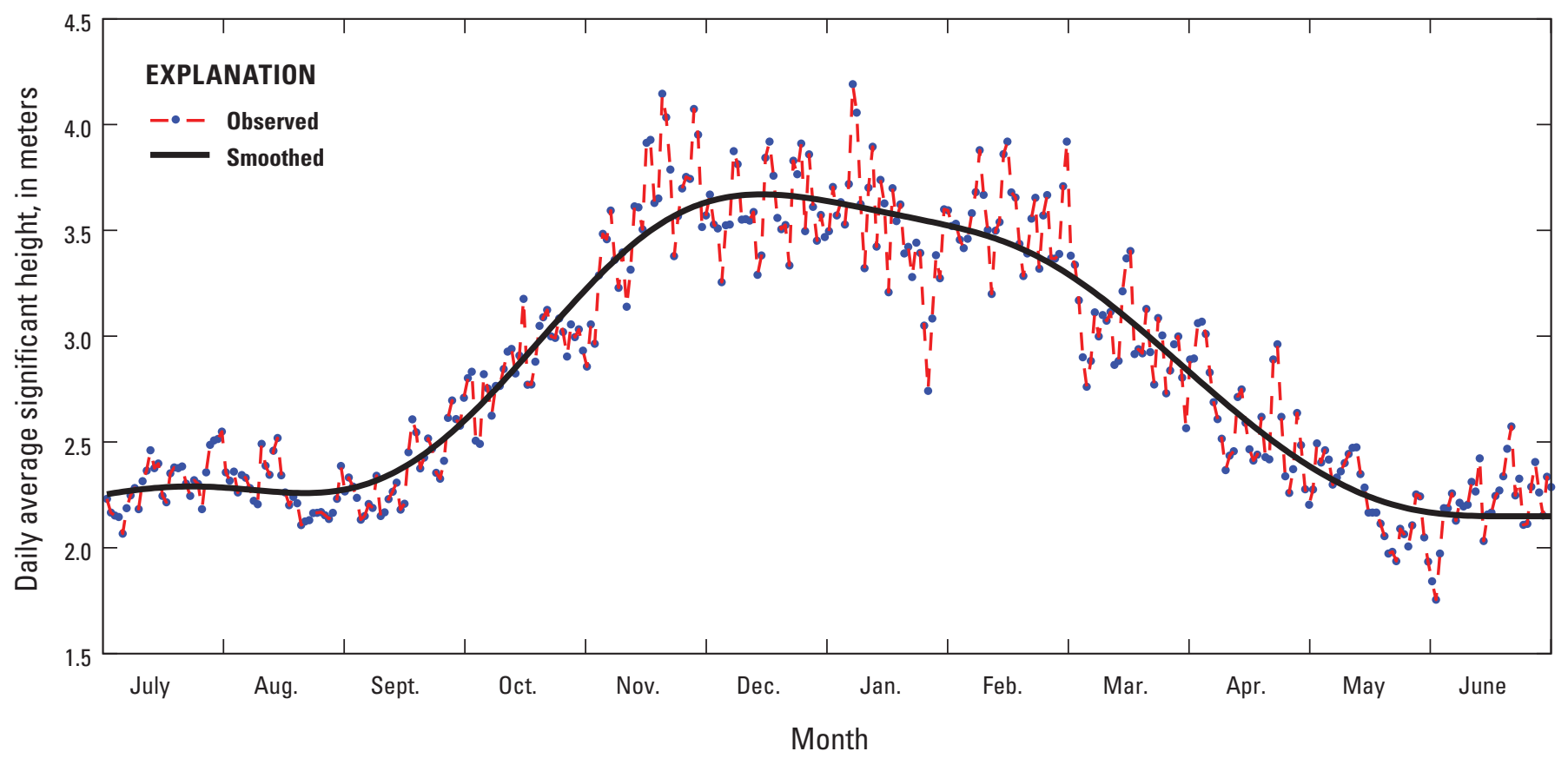

Figure 10. Daily average significant wave height from buoy 51001 (1981 to 2005, location shown in figure 8). This plot shows the seasonal variability of North Pacific Ocean swell, which begins to increase in October, reaches a peak in winter, decreases in March, and reaches a minimum in summer.

Occurring about 75 percent of the year, the trade winds are northeasterly (average, $73^{\circ}$ ) winds with an average speed of 25 kilometers per hour (16 miles per hour). Anticyclonic (clockwise) flow around the North Pacific high bolsters the trade winds in Hawaii in summer months, increasing their persistence. In winter months, the North Pacific high flattens and moves closer to the islands, decreasing the trade wind persistence (fig. 11). Although the number of days characterized by trade winds is greater in summer than in winter months, mean trade wind speed in summer and winter months is similar.
The persistent trade winds generate limited-fetch swell on north-, northeast-, east-, and southeast-facing coasts (fig. 8). Trade wind waves in Hawaii are characterized by choppy seas with average wave heights of $2 \mathrm{~m}$ and peak periods of 9 seconds from the northeast. These are nominal conditions, however, and trade wind waves can exceed $5 \mathrm{~m}$ in height and have periods of 15 to 20 seconds.

Southern swell arriving in Hawaii is typically generated farther away from the islands than North Pacific swell. These swells are generated by storms south of the equator

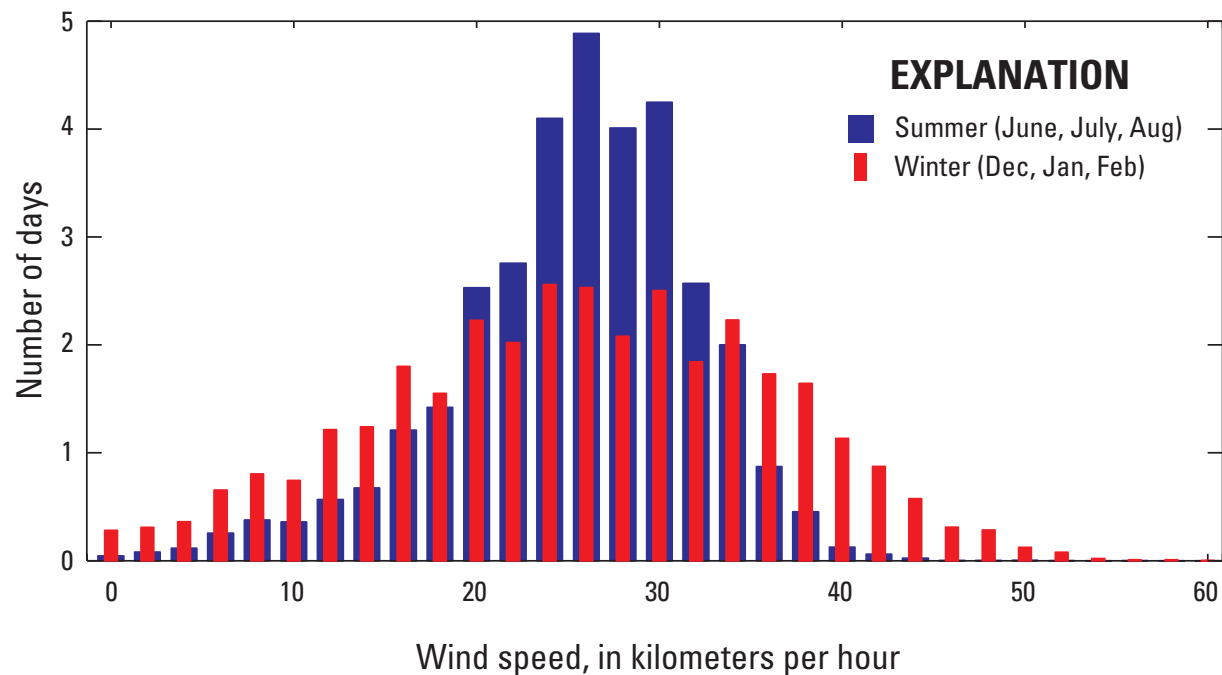

Wind speed, in kilometers per hour
Figure 11. Number of days per season that trade winds occur with a particular speed (data from buoy 51001, 1981 to 2005). Note the persistence of typical trade winds at a speed of about 25 kilometers per hour (16 miles per hour) during summer months. 
near Australia, New Zealand, and as far as Antarctic waters. Southern swell occurs in summer months (winter months in the southern hemisphere) and reaches Hawaii with an annual significant wave height of 2.5 to $3 \mathrm{~m}$ and peak periods of 14 to 22 seconds, which is a smaller but slightly longer period than North Pacific swell (Armstrong, 1983; Vitousek and Fletcher, 2008).

Kona storms generally refer to low-pressure areas (cyclones) of subtropical origin that usually develop northwest of Hawaii in winter and move slowly eastward, accompanied by southerly winds (from whose direction the storm derives its name) and by the clouds and rain that have made these storms synonymous with bad weather in Hawaii (Giambelluca and Schroeder, 1998). Strong Kona storms generate wave heights of 3 to $4 \mathrm{~m}$ with periods of 8 to 11 seconds, along with wind and rain, and can cause extensive damage to south- and west-facing shores (Rooney and Fletcher, 2005). Minor Kona storms occur nearly every year in Hawaii, however, major Kona storms resulting in substantial shoreline change tend to occur every 5 to 10 years, during the negative PDO cycle (Rooney and Fletcher, 2005). Consequently, positive (warm) PDO and El Niño phases tend to suppress Kona storm activity (Rooney and Fletcher, 2005).

Although each wave regime (trade wind swell, North Pacific swell, southern swell, and Kona storms) has its own underlying processes and mechanics, the sum of all of these regimes contributes to the wave heights and shoreline change in Hawaii. Breaking waves at the shoreline are composed of swell sources from many different storms and swell regimes. The most common combination of swell modes for northfacing shores is North Pacific swell and trade wind swell. The most common combination of swell modes for south-facing shores is southern swell and trade wind swell. Thus, the spectral approach to swell and surf patterns following Aucan (2006) is an informative way of depicting the Hawaiian wave climate.

The maximum annually recurring significant wave heights $\left(\mathrm{H}_{\mathrm{s}}\right)$ and the largest 10-percent $\left(\mathrm{H}_{1 / 10}\right)$ and 1-percent $\left(\mathrm{H}_{1 / 100}\right)$ wave heights for various directions in 30 degree windows around Hawaii are given in table 2 (Vitousek and Fletcher, 2008); annual wave heights are also depicted in figure 8 .

\section{Tides}

The tide range in Hawaii is comparatively small, typically 0.58 m (Mean Higher High Water (MHHW) - Mean Lower Low Water (MLLW)), and the spring tide range is about $1 \mathrm{~m}$. Although the astronomic tide typically represents the largest water-level variability at a particular location, other factors such as atmospheric pressure, wind setup, ENSO cycles, and oceanic disturbances can produce water-level variability on the order of tens of centimeters. One important process influencing extreme sea-level events in Hawaii is the occurrence of mesoscale eddies, which are large (greater than
Table 2. Observed maximum annually recurring significant wave heights $\left(\mathrm{H}_{\mathrm{s}}\right)$ and the largest 10-percent $\left(\mathrm{H}_{1 / 10}\right)$ and 1-percent $\left(\mathrm{H}_{1 / 100}\right)$ wave heights for various directions around Hawaii.

[Modified from Vitousek and Fletcher, 2008; Window, degrees from true north; $\mathrm{m}$, meters]

\begin{tabular}{rrrrc}
\hline \multirow{2}{*}{ Window (degrees) } & \multicolumn{3}{c}{ Annually recurring wave heights $(\mathbf{m})$} \\
\cline { 3 - 5 } & & $\mathbf{H}_{\mathbf{s}}$ & $\mathbf{H}_{\mathbf{1 / 1 0}}$ & $\mathbf{H}_{\mathbf{1} / 100}$ \\
\hline 0 & 30 & 5.9 & 7.4 & 9.8 \\
30 & 60 & 6.0 & 7.6 & 10.0 \\
60 & 90 & 5.1 & 6.5 & 8.5 \\
90 & 120 & 4.3 & 5.5 & 7.2 \\
120 & 150 & 2.8 & 3.5 & 4.6 \\
150 & 180 & 3.0 & 3.8 & 5.0 \\
180 & 210 & 2.4 & 3.0 & 3.9 \\
210 & 240 & 1.6 & 2.0 & 2.7 \\
240 & 270 & 1.5 & 1.9 & 2.5 \\
270 & 300 & 3.7 & 4.7 & 6.2 \\
300 & 330 & 5.9 & 7.5 & 9.9 \\
330 & 360 & 5.8 & 7.4 & 9.7 \\
\hline
\end{tabular}

$100 \mathrm{~km}$ ) oceanic disturbances with elevated sea levels of about $15 \mathrm{~cm}$ (Firing and Merrifield, 2004).

As discussed previously, many sources contribute to the maximum water level on a beach, including tide, wave setup, wave run-up, and other sources of water-level variability. Coincidence of large swell and tide events can cause severe coastal flooding and overtopping in Hawaii, whereas swell events that occur at low tides or neap cycles typically are less severe (Caldwell and others, 2009).

\section{Shoreline Change}

All the processes considered thus far influence beach morphology in Hawaii. Morphologic changes include seasonal beach profile changes, extreme events, and chronic trends. Seasonal beach-profile changes result from the seasonal variability of the Hawaiian wave cycle (see the Hawaii beach profile Web site at http://geopubs.wr.usgs.gov/open-file/ of01-308/). In winter months, north-facing shorelines are exposed to increased wave activity from the North Pacific swell. In summer months, south-facing shorelines are exposed to increased wave activity from the southern swell. This wave activity is associated with increased run-up and increased impacts to the beach and coastal dunes. Elevated energy at the shoreline transports sand offshore or alongshore with dominant currents. The beach profile remains in an adjusted state until wave heights decrease or swell patterns change to allow the displaced volume of sand to return. A conceptual example of cross-shore sand transport and profile change is shown in figure 12 . 


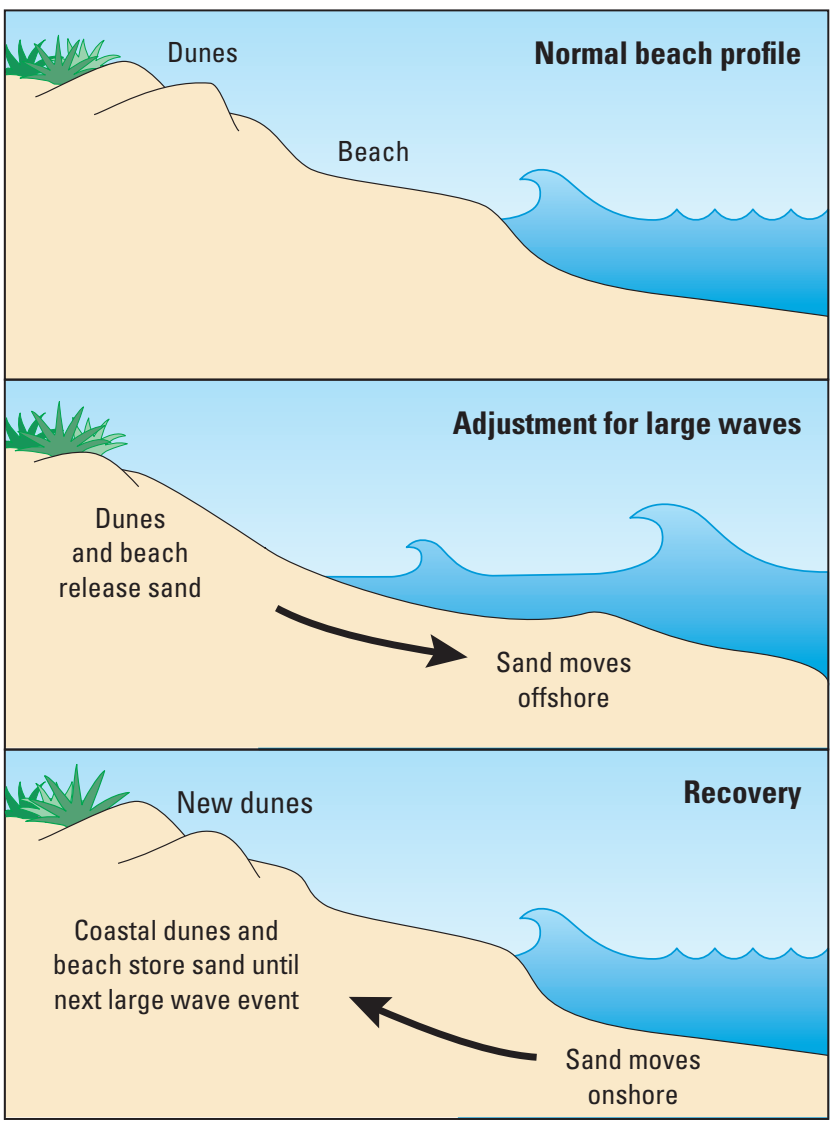

NOT TO SCALE

Figure 12. Seasonal beach-profile adjustments induced by seasonal swell variations and resulting cross-shore sediment transport.

Extreme beach profile changes, whose magnitude exceeds typical seasonal levels, result from extreme swell, storm, and sea-level events often associated with a corresponding ENSO or PDO cycle. Examples of extreme beach changes in Hawaii include the erosion that has occurred (2005-present) at Kailua Beach Park near the boat ramp during persistent windy conditions (La Niña), followed by the short-lived return of sand associated with the low wind (El Niño) conditions of winter 2009/2010. As the El Niño ended and La Niña winds returned, the sand at Kailua again disappeared, and erosion has dominated since. Another example of extreme beach fluctuations occurred in 2003 at Kaanapali Beach, Maui, as a result of the combination of high water levels caused by a mesoscale eddy juxtaposed with spring high tide, late summer heating, and a modest southern-swell event (Vitousek and others, 2007).

One of the main goals of this study was to quantify the extent of long-term or "chronic" erosion on Hawaiian shorelines. Chronic changes are long-term (decades to centuries) changes that do not show a cyclical pattern. Chronic beach changes or chronic erosion in Hawaii can result from longterm sea-level rise and sediment budget deficiency (often related to human activities).

\section{Methods of Analyzing Shoreline Change}

Coastal scientists have been quantifying rates of shoreline movement and studying coastal change for decades. Time series of shoreline positions can be used to document coastal change and are interpreted to improve our understanding of shoreline stability.

\section{Compilation of Historical Shorelines}

The most commonly used sources of historical shoreline data have traditionally been NOAA's National Ocean Service (NOS) Topographic sheets (T-sheets; Shalowitz, 1964) and vertical aerial photographs. Ideally, extraction of past shoreline positions from these data sources involves georeferencing and removing distortions from maps and aerial photographs, followed by digitizing the shoreline position.

Depending on location, data source, and scientific preference, different proxies are used to represent the position of the shoreline. Common shoreline proxies include the high water line (HWL) (Shalowitz, 1964); a wet-dry line (maximum runup; Moore and others, 2006); the first line of vegetation (for example, Hwang, 1981); the toe or crest of the abutting dune (Moore and Griggs, 2002); a low water line such as the toe of the beach (for example, Fletcher and others, 2003); a cliff base or top (for example, Hapke and Reid, 2007); and a tidal datum or elevation - typically the location where the plane of mean high water (MHW) intersects the beach face (for example, Morton and others, 2004).

In this study, the methods of Fletcher and others (2003) and Romine and others (2009) for mapping historical shorelines were followed closely. Historical shorelines were digitized from NOS T-sheets and orthorectified aerial photo mosaics with spatial resolution (pixel size) of $0.5 \mathrm{~m}$ (fig. 13).

Aerial photographs were orthorectified and mosaicked in PCI Geomatics, Inc., Geomatica Orthoengine software (http://www.pcigeomatics.com/) to reduce displacements caused by lens distortion, Earth curvature, refraction, camera tilt, and terrain relief. A Root Mean Square (RMS) positional error less than $2 \mathrm{~m}$ is commonly achieved. T-sheets are georeferenced using polynomial mathematical models in PCI with RMS errors typically less than $4 \mathrm{~m}$. Rectification of T-sheets is also verified by overlaying them on aerial photomosaics to compare their fit to unchanged features. Previous workers (Shalowitz, 1964; Crowell and others, 1991; Daniels and Huxford, 2001) who addressed the accuracy of T-sheets found that they meet national map accuracy standards 


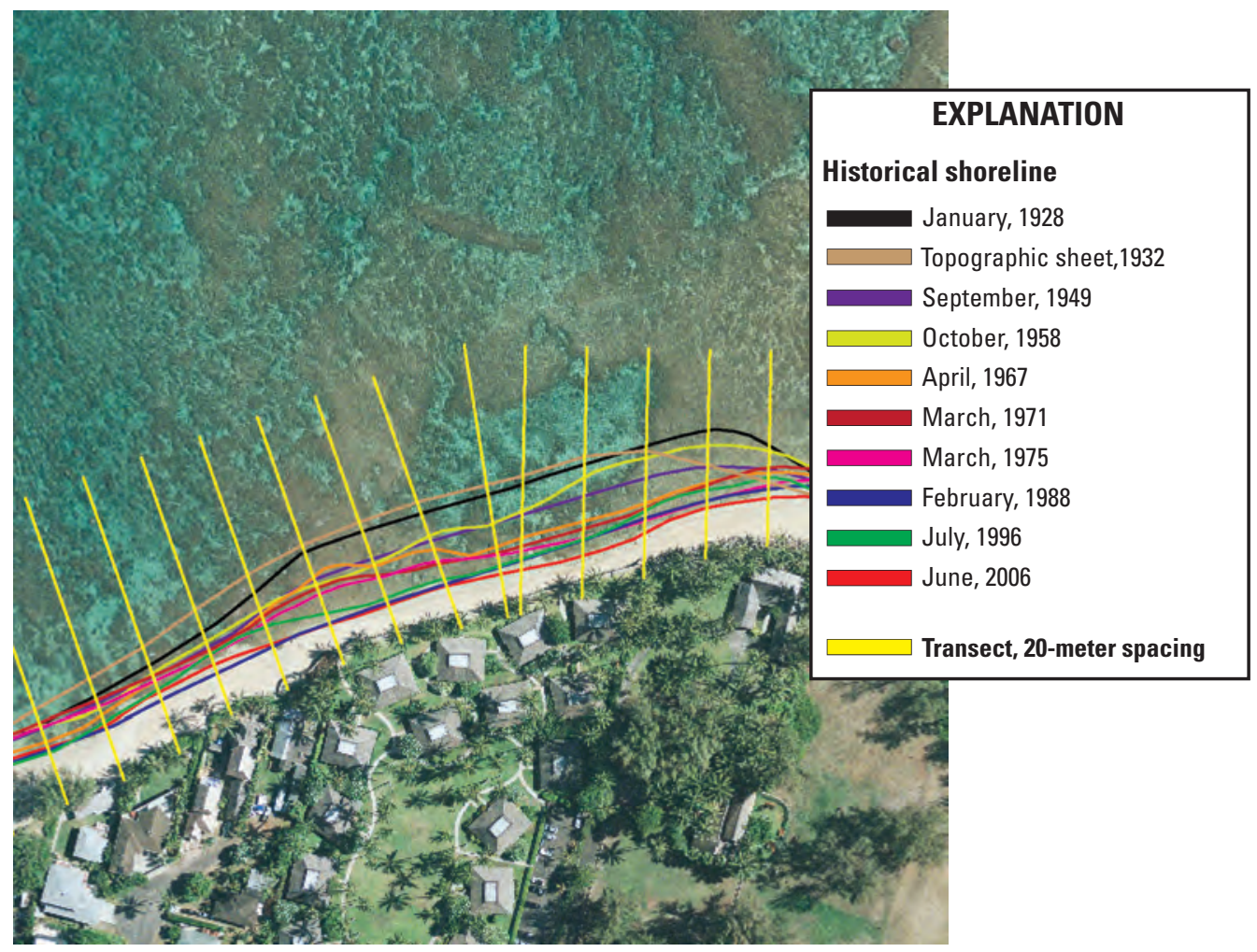

Figure 13. Historical shorelines and shoreperpendicular transects (20-meter spacing) displayed on a portion of a recent (2006) aerial photograph of Mokuleia Beach, North Oahu. (Location shown in figure 24) (Photograph by Hawaii Aviation, Inc.)
(Ellis, 1978) and recommended them for use in shoreline change studies as a valuable source of data needed to extend the time series of historical shoreline positions (National Academy of Sciences, 1990).

T-sheets were rectified using ERDAS, Inc., Imagine geographic imaging software (http://www.erdas.com/ Homepage.aspx) by placing a minimum of six ground control points (GCPs) distributed throughout the image on the T-sheet graticule. For some T-sheets produced before 1930 additional coordinate transformation information from NOAA was required to convert the data from the United States Standard Datum (USSD) to the North American Datum of 1927 (NAD 27). The datum transformation was applied to T-sheet graticule coordinates prior to rectification. Total RMS error for the rectification process was maintained below 1 pixel, which is approximately $4 \mathrm{~m}$ at a scale of 1:20,000 and approximately $1.5 \mathrm{~m}$ at a scale of $1: 10,000$. The resulting RMS error typically was much lower than 1 pixel.

To verify T-sheets and datum transformations, shoreline features that change little over the period of study (for example, rock headlands and engineered structures) were used. In the Hawaiian Islands, the adoption of the NAD 27 datum for mapping and the emergence of several unsupported local and island-specific datums have led to confusion among cartographers and surveyors. Many T-sheet products used in this study were re-rectified to correct substantial errors associated with incorrect projection datum definitions. Such errors otherwise would have rendered the sheets unusable.

Newly georeferenced T-sheets were loaded in ESRI (http://www.esri.com/) ArcGIS software and ArcToolBox was used to transform the T-sheets into the Universal Transverse Mercator (UTM) projection on the North American Datum of 1983 (NAD 83) prior to shoreline digitization. A verification of the T-sheet shoreline was carried out where possible using control marks or physical shoreline features that are present on the T-sheet by comparing them with a reliable current image. Where verification failed, T-sheets were re-rectified using ground control points on existing control stations and identifiable shoreline features. In all cases, shoreline-feature verification produced a high-quality data product.

\section{Mapping Historical Shorelines}

In Hawaii, the high reflectivity of Hawaiian white carbonate beaches reduces the visibility of the HWL on historical aerial photographs (Fletcher and others, 2003). Norcross and others (2002) and Eversole and Fletcher (2003) found that the low water mark (LWM) or toe of the beach was important as a pivot point for cross-shore and alongshore sediment-transport processes at their study sites at Kailua Beach, Oahu, and Kaanapali Beach, Maui, respectively. Excellent water clarity 
relative to most continental beaches allows the delineation of the LWM on historical aerial photomosaics, which is distinguished by a black and white or color tonal change at the base of the foreshore, most easily identified by the relative position of wave run-up on the beach.

A LWM was digitized from aerial photomosaics as the shoreline proxy. The beach toe, or base of the foreshore, is a geomorphic representation of the LWM. Removing or quantifying sources of uncertainty related to temporary changes in shoreline position is necessary to achieve the goal of identifying chronic long-term trends in shoreline movement. Using a LWM as a shoreline proxy on Hawaiian carbonate beaches offers several advantages toward the goal of limiting uncertainty. Studies from beach-profile surveys have shown that the LWM is less prone to geomorphic changes typical of other shoreline proxies (for example, wet-dry line and high water mark) on the landward portions of the beach (Norcross and others, 2002). The vegetation line was used as the shoreline proxy in some previous Oahu studies (Hwang, 1981; Sea Engineering, Inc., 1988). However, on many Hawaiian beaches the vegetation line is cultivated, fixed by shoreline revetments, obscured by overhanging trees, or dominated by aggressive species, and therefore may not represent natural erosion and accretion patterns.

The original surveyors working on T-sheets mapped the HWL as a shoreline proxy. To include T-sheet shorelines in the time series of historical shorelines, the HWL is migrated to a LWM in our study using an offset calculated from measurements in beach profile surveys at the study beach or a similar nearby location. To determine patterns of historical shoreline movement, changes in shoreline position were measured relative to an offshore baseline along shore-perpendicular transects spaced $20 \mathrm{~m}$ apart.

The migration of the HWL to the LWM was possible using topographic beach profiles. The USGS, in coordination with the University of Hawaii, conducted a 5 -year beach profile study at beaches on the islands of Oahu and Maui (Gibbs and others, 2001). University researchers have extended this survey to include the period 2006-08 on Oahu (35 locations; C.H. Fletcher, B.M. Romine, and M. Dyer, unpub. data, 2008) and on Kauai (27 locations; C.H. Fletcher, T.R. Anderson, and M. Dyer, unpub. data, 2008). Distances between the two shoreline features are calculated at the nearest representative beach profile location, and an average offset distance was calculated.

Additional details on the dates of specific shorelines and their spatial coverage are available in the companion online data report by Romine and others (2011).

\section{Uncertainty and Error}

Several sources of error affect the accuracy of historical shoreline positions and final shoreline change rates. In this report, two types of uncertainty are defined: positional uncertainty and measurement uncertainty. Following methods
Table 3. Range of errors in position of historical shorelines for Kauai, Oahu, and Maui.

[m, meters; \pm , plus or minus $]$

\begin{tabular}{llll}
\hline \multirow{2}{*}{ Source of error } & \multicolumn{3}{c}{ Magnitude range $(\mathbf{m})$} \\
\cline { 2 - 4 } & \multicolumn{1}{c}{ Maui } & \multicolumn{1}{c}{ Oahu } & \multicolumn{1}{c}{ Kauai } \\
\hline Seasonal error $\left(E_{s}\right)$ & $\pm 1.2-7.1$ & $\pm 3.6-6.2$ & $\pm 2.5-19.9$ \\
Tidal error $\left(E_{t d}\right)$ & \pm 1.4 & $\pm 2.5-3.4$ & $\pm 2-6$ \\
T-sheet conversion error $\left(E_{c}\right)$ & $\pm 1.9-7.5$ & $\pm 3.4-5.7$ & $\pm 1.0-13.8$ \\
Digitizing error $\left(E_{d}\right)$ & $\pm 0.8-5.1$ & $\pm 0.5-5.7$ & $\pm 0.8-9.7$ \\
Pixel error $\left(E_{p}\right)$ & \pm 0.5 & \pm 0.5 & $\pm 0.5-3.41$ \\
Rectification error $\left(E_{r}\right)$ & $\pm 0.1-6.1$ & $\pm 0.6-3.0$ & $\pm 0.0-7.3$ \\
T-sheet plotting error $\left(E_{t s}\right)$ & \pm 5.1 & \pm 5.1 & \pm 5.1 \\
\hline
\end{tabular}

of Romine and others (2009), and building on work by Fletcher and others (2003), Genz and others (2007a), Morton and others (2004), and Rooney and others (2003), seven different sources of error in identifying shoreline positions on aerial photographs and T-sheets (three positional and four measurement errors) were quantified. The seven sources of error are summed in quadrature (the square root of the sum of the squares) to arrive at a total positional uncertainty $\left(U_{t}\right)$. The range of values of each type of error for each island are listed in table 3.

Positional uncertainties, including errors related to seasons, tides, and T-sheet HWL-to-LWM shoreline conversions, are related to all phenomena that reduce the precision and accuracy of defining a shoreline position in a given year. These uncertainties center mostly on the nature of the shoreline position at the time an aerial photo is taken.

Seasonal error $\left(E_{s}\right)$ is the error associated with movements in shoreline position from waves and storms. In Hawaii, this movement is largely a seasonal process, with swell from the North Pacific in winter and South Pacific in summer (see Waves). Some beaches (or sections of beach) tend to accrete in summer and erode in winter, whereas other beaches tend to do the opposite as a result of seasonal shifts in predominant swell direction. Because seasonal change is cyclical, the probability of a photograph depicting a summer shoreline is equal to the probability of a photograph depicting a winter shoreline. Therefore, a uniform distribution is an adequate approximation of seasonal uncertainty. Seasonal differences in shoreline position (LWM) were quantified from summer and winter beach profile measurements at a study beach or nearby beach with similar littoral characteristics. If available, seasonal shoreline positions from aerial photographs taken in adjacent seasons can be used in place of beach profile data. The mean and standard deviation of seasonal changes were calculated from the absolute values of differences between summer 
and winter shoreline positions. A uniform distribution was generated (with MatLab rand function) that incorporates the mean and two times the standard deviation as minimum and maximum values. The standard deviation of the distribution is the seasonal error.

Tidal fluctuation error $\left(E_{t d}\right)$ is the error from horizontal movement in shoreline position along a beach profile due to vertical tides. Aerial photographs were obtained without regard to tidal cycles, which can influence the position of the digitized shoreline. The horizontal movement of the LWM during a spring tidal cycle was monitored on several beaches to assess this error. Because the tides cyclically fluctuate between low and high, a photograph can capture the shoreline at any tidal stage. Therefore, like seasonal error, a uniform distribution is an adequate approximation of tidal uncertainty. A uniform distribution is generated that incorporates the mean and two times the standard deviation as minimum and maximum values. The tidal error is the standard deviation of the distribution.

Conversion error $\left(E_{c}\right)$ is calculated only for T-sheets and is the error associated with migration of T-sheet HWL shorelines to a LWM position. The error is the standard deviation of the differences between the offset and HWL-to-LWM beach profile measurements.

Measurement uncertainties, including errors related to shoreline digitization, image resolution, image rectification, and T-sheet plotting, are related to analyst manipulation of the map and photo products. For T-sheets, National Map Accuracy Standards (U.S. Bureau of the Budget, 1947) were adopted that provide a measure of both position and measurement uncertainties. For photos, measurement uncertainty is related to the orthorectification process and onscreen delineation of the shoreline.

Digitizing error $\left(E_{d}\right)$ is the error associated with digitizing the shoreline. One analyst digitizes the shorelines for all photographs and T-sheets to eliminate the possibility of different interpretations by multiple analysts. The error is the standard deviation of the differences (distances) between repeated digitizations by several analysts. The error is calculated for photos/T-sheets at different resolutions.

Pixel error $\left(E_{p}\right)$ is the pixel size of the image. The pixel size in orthorectified images is $0.5 \mathrm{~m}$, which means that any feature smaller than $0.5 \mathrm{~m}$ cannot be resolved. The pixel size in T-sheets is 1.0 to $3.0 \mathrm{~m}$.

Rectification error $\left(E_{r}\right)$ is calculated from the orthorectification process. Aerial photographs are corrected, or rectified, to reduce displacements caused by lens distortions, refraction, camera tilt, and terrain relief using PCI Orthoengine. The RMS values calculated by the software are measures of the offset between points on a photo and established GCPs. The rectification error is the RMS value.

T-sheet plotting error $\left(E_{t s}\right)$ is calculated only for T-sheets. The error is based on the analysis of topographic surveys by Shalowitz (1964). Three major errors are involved in the following accuracy of T-sheet surveys: (1) measured distance has an accuracy of $1 \mathrm{~m}$, (2) planetable plotting has an accuracy of $3 \mathrm{~m}$, and (3) delineation of the HWL on the beach has an accuracy of $4 \mathrm{~m}$. The three errors are summed in quadrature to obtain the T-sheet plotting error.

These errors are random and uncorrelated and can be represented by a single measure calculated by summing in quadrature, (equation 1). The total positional uncertainty $\left(U_{t}\right)$ is

$$
U_{t}= \pm \sqrt{E_{s}^{2}+E_{t d}^{2}+E_{c}^{2}+E_{d}^{2}+E_{p}^{2}+E_{r}^{2}+E_{t s}^{2}}
$$

For aerial photographs, $E_{c}$ and $E_{t s}$ are omitted. For T-sheets, $E_{t d}$ is omitted. $U_{t}$ is used as the accuracy attribute field for each shoreline year. These uncertainty values can be propagated into the shoreline change result using weighted linear regression (or weighted least squares, WLS) in the Digital Shoreline Analysis System (DSAS) (Thieler and others, 2009). The resulting uncertainty in the rate incorporates the uncertainty in each shoreline and the uncertainty in the ratedetermining model.

\section{Calculation and Presentation of Rates of Change}

Rates of shoreline change were generated in ArcGIS with DSAS version 4, an ArcMap extension developed by the USGS (Thieler and others, 2009). DSAS employs the singletransect method (ST) to calculate change rates and rate uncertainties at regularly spaced transects (measurement locations) alongshore. ST uses various methods (for example, end point rate, least squares, weighted least squares) to fit a trend line to the time series of historical shoreline positions at a transect. $\mathrm{ST}$ is the most commonly utilized method for calculating shoreline change (for example, see Fletcher and others, 2003; Morton and others, 2004; Morton and Miller, 2005; Hapke and others, 2006; Hapke and Reid, 2007).

Transects were spaced approximately at $20-\mathrm{m}$ intervals alongshore, roughly perpendicular to the trend of the shoreline. Hawaiian beaches are typically narrower and shorter than mainland beaches. To adequately characterize change on Hawaiian beaches, the transect spacing used was narrower than that typically employed in studies of mainland U.S. beaches (for example, $50 \mathrm{~m}$; Morton and others, 2004; Morton and Miller, 2005).

Shoreline change rates were calculated with ST using WLS regression, which accounts for uncertainty in each shoreline position when calculating a trend line. The weight for each shoreline position is the inverse of the uncertainty squared (for example, $w_{i}=1 / U_{t}^{2}$ ). Shoreline positions with higher uncertainty have less influence on the trend line than data points with smaller uncertainty. The slope of the line is the shoreline change rate (fig. 14).

Rates were calculated for long- and short-term shoreline data. All shorelines were used for long-term rate calculations, and post-WWII shorelines were used for short-term rate calculations. A minimum of three historical shoreline positions 


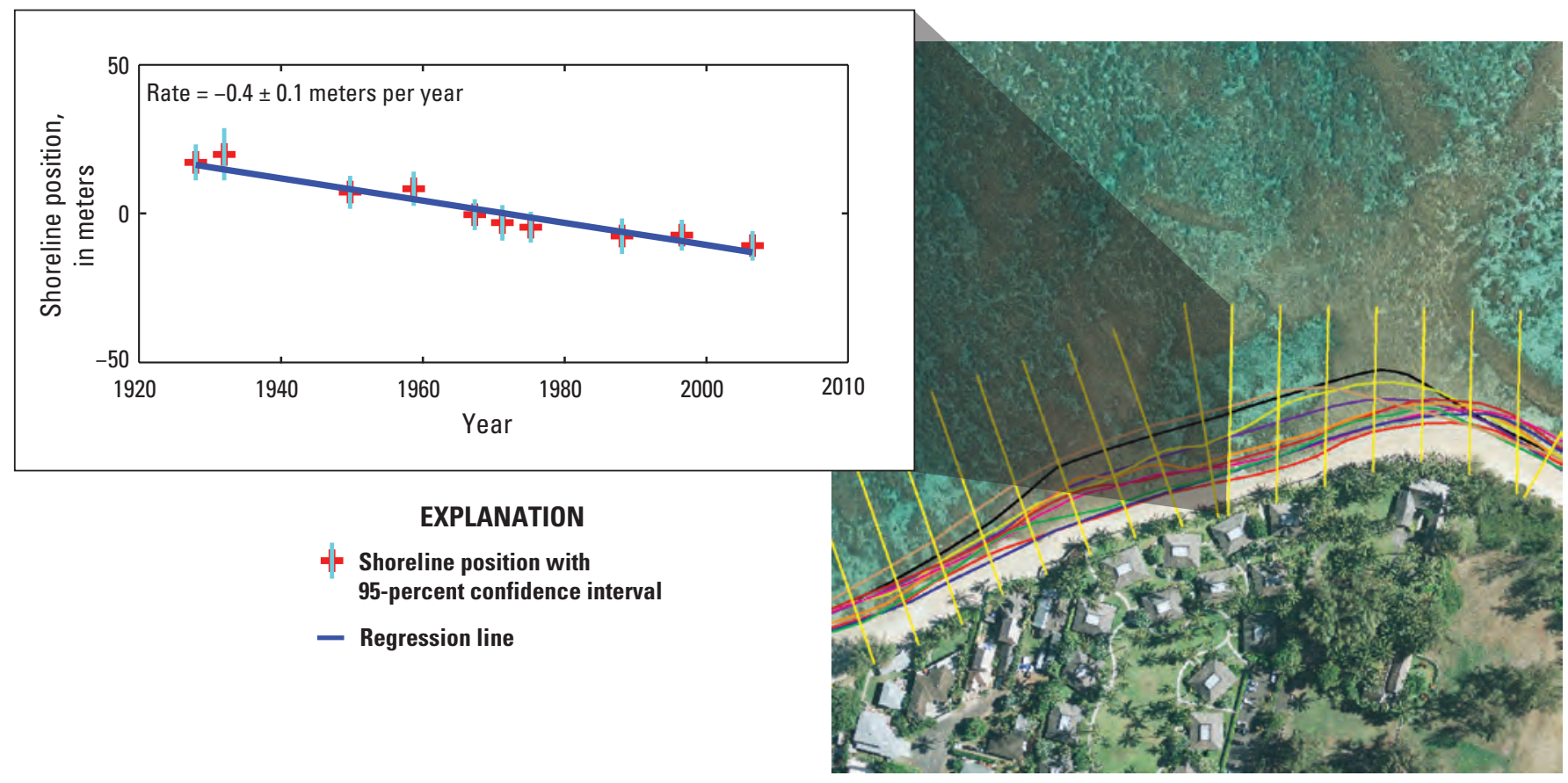

Figure 14. Calculation of shoreline change rate from a time series of shoreline positions using the single-transect method. The slope of the line is the annual shoreline change rate. (See figure 13 for explanation of photograph)

is required when calculating a shoreline change rate with WLS. Transects with less than three shoreline intersections are given a 'null' rate and are not included in calculating regionally averaged rates. In some instances, the beach disappeared over the course of the study period. In these cases, rates were calculated using only shorelines up to and including the first shoreline indicating no beach. The total extent of beach lost in a region is estimated by multiplying the number of transects where the beach was lost times $20 \mathrm{~m}$ (20-m transect spacing). The percent of beach lost in a region is the number of transects where the beach was lost divided by the total number of transects.

Historical shoreline data typically are sparse (commonly less than 10 shorelines) and noisy (high positional uncertainty). Consequently, shoreline change rates tend to have high uncertainty, resulting in many rates that are not statistically significant. For this study, an insignificant rate was defined as a rate that is indistinguishable from a rate of $0 \mathrm{~m} / \mathrm{yr}$; in other words, the calculated \pm rate uncertainty overlaps $0 \mathrm{~m} / \mathrm{yr}$. Rates that are statistically insignificant still provide coastal managers with a most likely scenario of shoreline change - valuable information for assessing the risk of future shoreline erosion. Reducing the uncertainty in shoreline change rates using improved statistical methods will assist coastal managers in making more informed, science-based decisions when planning for future erosion hazards.

Regionally averaged shoreline change rates are the average of rates from all transects in a coastal region. The 95-percent confidence interval on the linear regression at each transect is assumed to be random and independent. Therefore, the uncertainty of an average rate $\left(U_{\text {avg }}\right)$ can be calculated as the root sum of squares of rate uncertainties $\left(U_{i}\right)$ at all transects divided by $n$ :

$$
U_{\text {avg }}=\frac{\sqrt{\sum_{i=1}^{n} U_{i}^{2}}}{n}
$$

The resulting average rate and uncertainty are often small relative to rates from individual transects. The greater the number of transects over which the uncertainty is averaged, the smaller the uncertainty of the average rate. To avoid reporting statistically significant average rates as indicating no change or having zero uncertainty, average rates were reported at higher precision (centimeters per year, $0.00 \mathrm{~m} / \mathrm{yr}$ ) than rates from individual transects (decimeters per year, $0.0 \mathrm{~m} / \mathrm{yr}$ ).

\section{Historical Shoreline Change Analysis}

\section{Kauai}

Kauai, is the northernmost populated island in the state. Kauai is more than 5 million years old and has a roughly circular shape as a result of at least one, and perhaps two, shield volcanoes. More than 1.5 million years after the primary shield-building stage had ceased, rejuvenated volcanism (the 
Koloa Volcanic Series) began resurfacing two thirds of the eastern side of the island. Kauai has approximately $75 \mathrm{~km}$ of sandy beach that is separated into four regions: north, east, south, and west (fig. 15).

From 3 to 11 historical shorelines with dates ranging from 1926 to 2008 are available for Kauai (table 4). The 1927 shoreline is derived from a T-sheet and the 1930 shoreline is from a hydrographic chart. All other shorelines are derived from vertical aerial photographs.

Erosion is the general long-term trend of Kauai beaches (table 5). During the analysis period, $6.1 \mathrm{~km}$ or 8 percent of the total extent of Kauai beaches was lost to erosion. The average of long-term rates for all Kauai transects is -0.11 $\pm 0.01 \mathrm{~m} / \mathrm{yr}$ and 71 percent of transects indicate a trend of erosion. The short-term average rate for Kauai suggests stable or accreting beaches at $0.02 \pm 0.02 \mathrm{~m} / \mathrm{yr}$. However, the majority ( 57 percent) of transects still indicate a trend of erosion in the short term. Overall reduced erosion in the short term for Kauai beaches is due largely to a change in average rates along West Kauai from erosion in the long term to accretion in the short term. The minimum and maximum longterm shoreline change rates on Kauai are measured near Koki Point in South Kauai (erosion, $-1.5 \pm 0.4 \mathrm{~m} / \mathrm{yr}$ ) and at Major's Bay in West Kauai (accretion, $1.6 \pm 1.8 \mathrm{~m} / \mathrm{yr}$ ) (table 6). The maximum short-term change rates are measured at Lawai Bay in South Kauai (erosion, $-1.7 \pm 9.9 \mathrm{~m} / \mathrm{yr}$ ) and at Polihale in West Kauai (accretion, $2.8 \pm 6.2 \mathrm{~m} / \mathrm{yr}$ ). The rate at Lawai is associated with a high degree of uncertainty because the beach was lost to erosion and a truncated data set was used to calculate the rate up to the time the beach disappeared. The rate at Polihale is associated with a high degree of uncertainty as a result of seasonal variability.

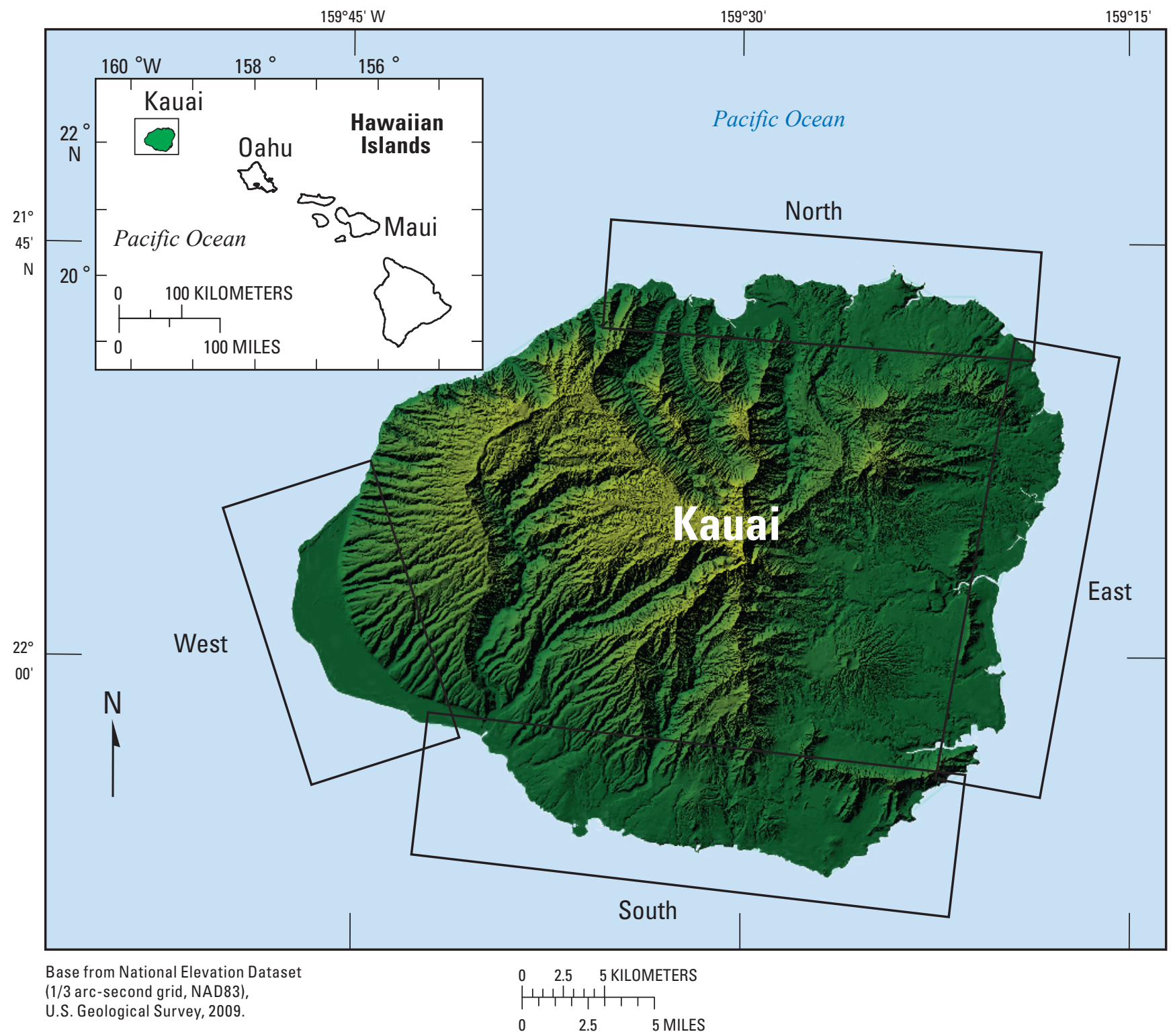

Figure 15. Four regions of Kauai: north, east, south, and west. 
Table 4. Number and range in years of historical shorelines for long- and short-term shoreline change analysis on Kauai.

\begin{tabular}{|c|c|c|c|c|}
\hline \multirow{3}{*}{ Region } & \multicolumn{4}{|c|}{ Shoreline change } \\
\hline & \multicolumn{2}{|c|}{ Long-term } & \multicolumn{2}{|c|}{ Short-term } \\
\hline & Number of shorelines ${ }^{1}$ & Range in years ${ }^{1}$ & Number of shorelines ${ }^{1}$ & Range in years ${ }^{1}$ \\
\hline North & $4-11$ & 1927-2008 & $3-10$ & 1950-2008 \\
\hline East & $3-9$ & $1927-2008$ & $3-8$ & $1950-2008$ \\
\hline South & $3-8$ & $1926-2008$ & $3-7$ & $1950-2008$ \\
\hline West & $3-9$ & 1926-2006 & $3-8$ & 1950-2006 \\
\hline
\end{tabular}

${ }^{1}$ Number of shorelines and range in years vary in each region.

Table 5. Shoreline change trends for Kauai, Oahu, and Maui.

[km, kilometers; m/yr, meters per year; LT, long-term; ST, short-term]

\begin{tabular}{|c|c|c|c|c|c|c|c|c|c|}
\hline \multirow{2}{*}{ Region } & \multirow{2}{*}{$\begin{array}{l}\text { Number of } \\
\text { transects }\end{array}$} & \multirow{2}{*}{$\begin{array}{c}\text { Beach loss } \\
(\mathbf{k m})\end{array}$} & \multirow{2}{*}{$\begin{array}{c}\text { Beach loss } \\
\text { (percent) }\end{array}$} & \multicolumn{2}{|c|}{ Average rate $(\mathrm{m} / \mathrm{yr})$} & \multicolumn{2}{|c|}{ Percent eroding } & \multicolumn{2}{|c|}{ Percent accreting } \\
\hline & & & & LT & ST & LT & ST & LT & ST \\
\hline \multicolumn{10}{|c|}{ Kauai } \\
\hline North & 1,104 & 1.7 & 8 & $-0.11 \pm 0.02$ & $-0.06 \pm 0.02$ & 76 & 60 & 23 & 38 \\
\hline East & 867 & 1.0 & 6 & $-0.15 \pm 0.02$ & $-0.06 \pm 0.02$ & 78 & 63 & 19 & 33 \\
\hline South & 790 & 1.9 & 14 & $-0.01 \pm 0.02$ & $0.05 \pm 0.04$ & 63 & 57 & 34 & 39 \\
\hline West & 962 & 1.5 & 7 & $-0.13 \pm 0.04$ & $0.16 \pm 0.08$ & 64 & 48 & 33 & 49 \\
\hline Total & 3,723 & 6.1 & 8 & $-0.11 \pm 0.01$ & $0.02 \pm 0.02$ & 71 & 57 & 27 & 40 \\
\hline \multicolumn{10}{|c|}{ Oahu } \\
\hline North & 1,287 & 0.2 & 1 & $-0.11 \pm 0.01$ & $-0.07 \pm 0.01$ & 73 & 68 & 25 & 30 \\
\hline East & 2,108 & 5.5 & 13 & $0.01 \pm 0.01$ & $-0.01 \pm 0.01$ & 50 & 54 & 47 & 44 \\
\hline South & 1,319 & 3.0 & 11 & $-0.04 \pm 0.01$ & $-0.03 \pm 0.02$ & 50 & 47 & 48 & 50 \\
\hline West & 628 & 0.0 & 0 & $-0.25 \pm 0.01$ & $-0.13 \pm 0.02$ & 83 & 71 & 16 & 27 \\
\hline Total & 5,342 & 8.7 & 8 & $-0.06 \pm 0.01$ & $-0.05 \pm 0.01$ & 60 & 58 & 38 & 40 \\
\hline \multicolumn{10}{|c|}{ Maui } \\
\hline North & 903 & 0.9 & 6 & $-0.26 \pm 0.02$ & $-0.22 \pm 0.03$ & 87 & 74 & 12 & 16 \\
\hline Kihei & 1,011 & 2.1 & 11 & $-0.13 \pm 0.01$ & $-0.12 \pm 0.02$ & 83 & 77 & 16 & 20 \\
\hline West & 1,519 & 3.8 & 14 & $-0.15 \pm 0.01$ & $-0.13 \pm 0.01$ & 85 & 77 & 14 & 18 \\
\hline Total & 3,433 & 6.8 & 11 & $-0.17 \pm 0.01$ & $-0.15 \pm 0.01$ & 85 & 76 & 14 & 18 \\
\hline \multicolumn{10}{|c|}{ Hawaii (all beaches studied) } \\
\hline Total & 12,498 & 21.5 & 9 & $-0.11 \pm 0.01$ & $-0.06 \pm 0.01$ & 70 & 63 & 28 & 34 \\
\hline
\end{tabular}


Table 6. Maximum shoreline change rates on Kauai.

[m/yr, meters per year; max., maximum; \pm , plus or minus]

\begin{tabular}{|c|c|c|c|c|}
\hline Region & $\begin{array}{c}\text { Long-term rate } \\
(\mathrm{m} / \mathrm{yr})\end{array}$ & Location ${ }^{1}$ & $\begin{array}{c}\text { Short-term rate } \\
(\mathrm{m} / \mathrm{yr})\end{array}$ & Location' ${ }^{1}$ \\
\hline \multicolumn{5}{|c|}{ North } \\
\hline Max. erosion & $-0.7 \pm 0.6$ & Haena Point & $-1.0 \pm 2.6$ & Kauapea, seasonal variability \\
\hline Max. accretion & $0.7 \pm 0.7$ & Hanalei Bay, near middle & $0.8 \pm 1.5$ & Kahili Beach, near Kilauea Stream \\
\hline \multicolumn{5}{|c|}{ East } \\
\hline Max. erosion & $-0.7 \pm 0.4$ & Aliomanu Beach, west end & $-1.6 \pm 0.3$ & Anahola, Kuaehu Point \\
\hline Max. accretion & $0.7 \pm 0.4$ & Anahola Stream mouth & $1.1 \pm 0.6$ & Anahola Stream mouth \\
\hline \multicolumn{5}{|c|}{ South } \\
\hline Max. erosion & $-1.5 \pm 0.4$ & Pocket Beach near Koki Point ${ }^{2}$ & $-1.7 \pm 9.9$ & Lawai Bay, east end, beach lost ${ }^{2}$ \\
\hline Max. accretion & $1.4 \pm 0.7$ & Waimea, east side Kikiaola Harbor & $1.7 \pm 0.3$ & Waimea, east side Kikiaola Harbor \\
\hline \multicolumn{5}{|c|}{ West } \\
\hline Max. erosion & $-1.4 \pm 0.2$ & Oomano, west side Kikiaola Harbor & $-1.5 \pm 0.3$ & Oomano, west side Kikiaola Harbor \\
\hline Max. accretion & $1.6 \pm 1.8$ & Majors Bay, seasonal variability ${ }^{2}$ & $2.8 \pm 6.2$ & Polihale, seasonal variability ${ }^{3}$ \\
\hline
\end{tabular}

\section{North Kauai}

The backshore of Kauai's north coast is composed of rejuvenated volcanic basalt. The shoreline is characterized mostly by embayments and fringing reef systems. The shore is exposed to large North Pacific swell in winter and northeast trade wind waves throughout the year. The beaches tend to be steep and are composed of coarse-grained calcareous sand (Fierstein and Fletcher, 2004).

The eastern end contains extensive fringing reef systems and pocket beaches between volcanic headlands. The beach at Hanalei Bay, the largest bay on Kauai, is composed of a mix of calcareous and terrigenous sand. The Na Pali cliffs are west of Haena and contain intermittent calcareous pocket beaches (Fierstein and Fletcher, 2004). The beaches of the Na Pali region were not analyzed in this study.

The North region of Kauai is composed of three subregions (fig. 16). There are from 4 to 11 shorelines, with dates ranging from 1927 to 2008 (table 4). For the 1,104 transects, 13 percent of short-term rates and 18 percent of long-term rates are statistically significant (fig. 16). Low rate significance on North Kauai beaches may be attributed, in part, to high seasonal variability (noise) from short-term erosion during large winter waves.

The average long-term rate for all transects in North Kauai is $-0.11 \pm 0.02 \mathrm{~m} / \mathrm{yr}$ (table 5 ). Seventy-six percent of transects are erosional in the long term and 23 percent are accretional. The remaining 1 percent of transects have rates of $0 \mathrm{~m} / \mathrm{yr}$ or rates were not determined as a result of limited data. The maximum long-term erosion rate $(-0.7 \pm 0.6 \mathrm{~m} / \mathrm{yr})$ was found immediately west of Haena Point. Other locations with significant long-term erosion rates include Moloaa (up to $-0.4 \pm 0.2 \mathrm{~m} / \mathrm{yr}$ ) and Anini (up to $-0.4 \pm 0.1 \mathrm{~m} / \mathrm{yr}$ ). The maximum long-term accretion rate $(0.7 \pm 0.7 \mathrm{~m} / \mathrm{yr})$ was found near the middle of the $3.5-\mathrm{km}$-long crescent-shaped beach at Hanalei, which is accreting along most of its length. The Hanalei subregion is a notable exception to the predominant trend of erosion along North Kauai. The beach at Hanalei Bay is accreting at an average long-term rate of $0.11 \pm$ $0.03 \mathrm{~m} / \mathrm{yr}$, whereas the Kilauea and Haena subregions are eroding at $-0.13 \pm 0.03 \mathrm{~m} / \mathrm{yr}$ and $-0.23 \pm 0.03 \mathrm{~m} / \mathrm{yr}$, respectively (table 7).

In North Kauai, the average short-term rate $(-0.06 \pm$ $0.02 \mathrm{~m} / \mathrm{yr}$ ) indicates less erosion than the average long-term rate. Sixty percent of transects are erosional in the short term - a 16-percent decrease from the long-term rate. As with the long-term analysis, Hanalei is the largest exception to the overall trend of short-term erosion along North Kauai. The maximum short-term erosion rate $(-1.0 \pm 2.6 \mathrm{~m} / \mathrm{yr})$ was found at a rocky outcrop at Kauapea (table 6). This section of beach is susceptible to seasonal changes in shoreline position, as indicated by the high associated uncertainty. The maximum accretion rate $(0.8 \pm 1.5 \mathrm{~m} / \mathrm{yr})$ was measured at Kahili Beach near Kilauea Stream mouth. This beach is also highly unstable as a result of seasonal fluctuations in shoreline position from large waves and stream flow. Higher short-term accretion rates 


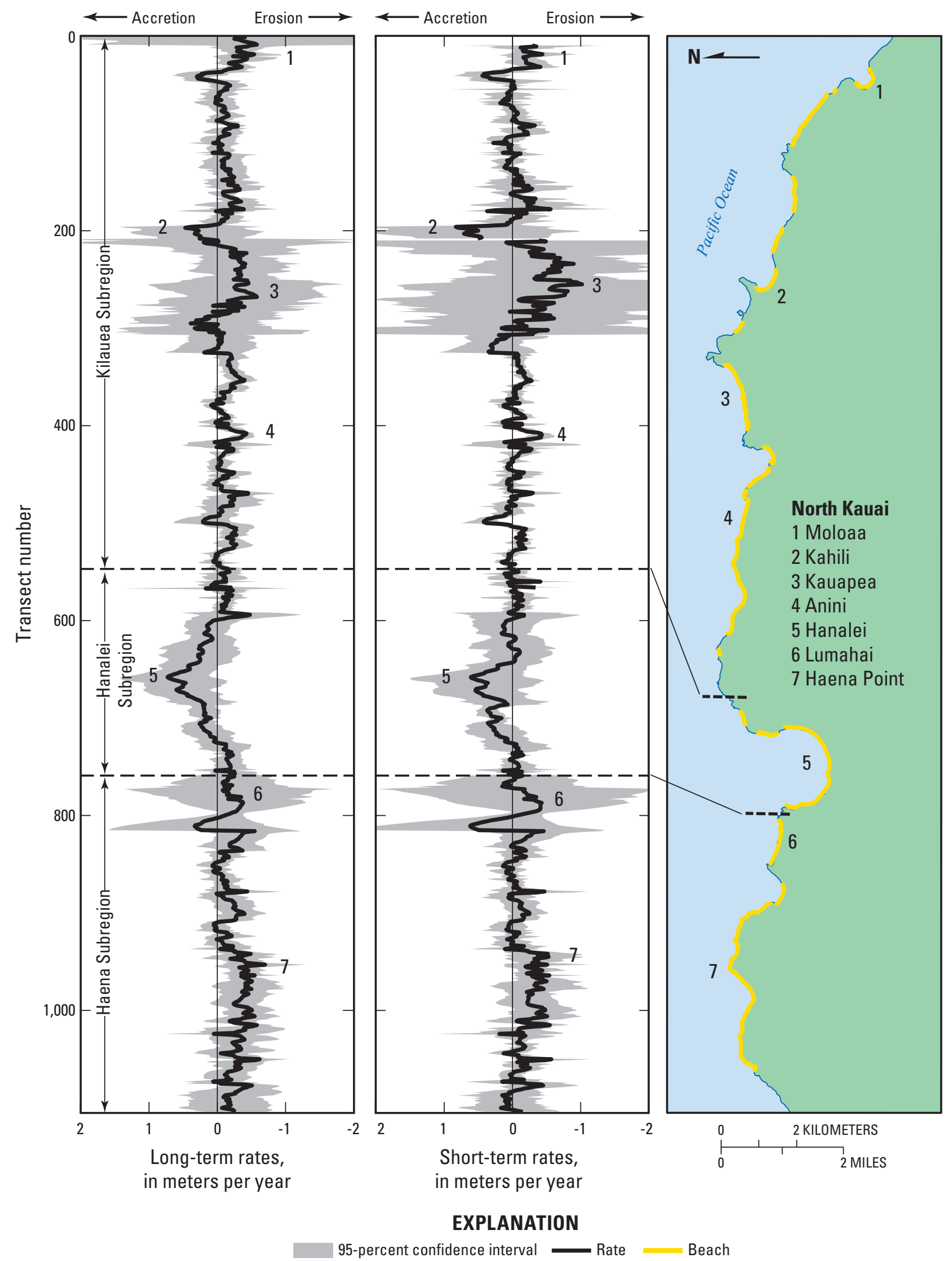

Figure 16. Long-term (all available years) and short-term (1940s to present) shoreline change rates, North Kauai. (Location shown in figure 15) 
Table 7. Average shoreline change rates for Kauai subregions.

$[\mathrm{m} / \mathrm{yr}$, meters per year; \pm , plus or minus $]$

\begin{tabular}{llccc}
\hline \multirow{2}{*}{ Region } & Subregion & \multirow{2}{*}{$\begin{array}{c}\text { Number of } \\
\text { transects }\end{array}$} & \multicolumn{2}{c}{ Average rate (m/yr) } \\
\cline { 4 - 5 } \multirow{*}{*}{ North } & Kilauea & 546 & $-0.13 \pm 0.03$ & $-0.09 \pm 0.04$ \\
& Hanalei & 212 & $0.11 \pm 0.03$ & $0.10 \pm 0.03$ \\
& Haena & 346 & $-0.23 \pm 0.03$ & $-0.12 \pm 0.03$ \\
\hline \multirow{3}{*}{ East } & Lihue & 267 & $-0.15 \pm 0.02$ & $-0.02 \pm 0.03$ \\
& Kapaa & 315 & $-0.17 \pm 0.02$ & $-0.08 \pm 0.02$ \\
& Anahola & 285 & $-0.13 \pm 0.04$ & $-0.07 \pm 0.05$ \\
\hline \multirow{3}{*}{ South } & Waimea & 128 & $0.74 \pm 0.05$ & $0.95 \pm 0.04$ \\
& Hanapepe & 360 & $-0.16 \pm 0.03$ & $-0.15 \pm 0.04$ \\
& Poipu & 123 & $-0.15 \pm 0.04$ & $-0.12 \pm 0.05$ \\
& Mahaulepu & 179 & $-0.15 \pm 0.03$ & $-0.08 \pm 0.13$ \\
\hline \multirow{3}{*}{ West } & Polihale & 272 & $-0.14 \pm 0.07$ & $0.37 \pm 0.11$ \\
& Barking Sands & 585 & $-0.04 \pm 0.06$ & $0.18 \pm 0.11$ \\
& Oomano & 105 & $-0.64 \pm 0.03$ & $-0.44 \pm 0.02$ \\
\hline
\end{tabular}

were found at transects $2(0.9 \pm 29.4 \mathrm{~m} / \mathrm{yr})$ and $567(1.0 \pm$ $13.0 \mathrm{~m} / \mathrm{yr}$ ). Neither rate is reported as the maximum accretion rate due to low confidence in these results (high rate uncertainty) where the beach was completely lost to erosion and only one historical shoreline indicated a beach present (the remainder were rocky shoreline).

Along the North Kauai coast, short- and long-term rates follow similar trends (fig. 16). Predictably, the short-term rates are associated with a greater degree of uncertainty than the long-term rates (because fewer shorelines were measured for short-term rates). Kauapea and Lumahai have high uncertainty bands for both short-term and long-term trends, likely because of the strong seasonal influence on the data. Therefore, linear methods do not result in a good fit for these data. Spikes in short-term uncertainty values at Moloaa, and Kahili are the result of calculating rates from a truncated data set (few shorelines) where the beach has been completely lost to erosion.

\section{East Kauai}

Kauai's eastern coast is characterized by embayments and fringing reef systems. The shore is exposed to northeast trade winds. Streams and rivers flow into the embayments, sometimes causing coastal flooding (Fierstein and Fletcher, 2004). The Kapaa region of this coast was once a series of embayments, but has been straightened as a result of sediment infilling (Moberly and Chamberlain, 1964; Fierstein and Fletcher, 2004).
East Kauai is the most erosional region of Kauai, as indicated by average shoreline change rates and percentages of transects that are indicative of erosion (table 5). The East region consists of three subregions (fig. 17). There are from three to nine shorelines that range in date from 1927 to 2008 (table 4). For the 867 transects, 34 percent of long-term rates and 16 percent of short-term rates are significant (fig. 17). The average long-term rate is $-0.15 \pm 0.02 \mathrm{~m} / \mathrm{yr}$, the most erosional rate of the four Kauai regions. Seventy-eight percent of transects are erosional in the long term. East Kauai has the lowest percentage of accreting transects (19 percent) of the four Kauai regions. The maximum long-term erosion rate $(-0.7 \pm 0.4 \mathrm{~m} / \mathrm{yr})$ was measured at the western end of Aliomanu Beach. Other areas of significant long-term erosion are found at Nukolii (up to $-0.5 \pm 0.3 \mathrm{~m} / \mathrm{yr}$ ) and north of Waipouli (up to $-0.3 \pm 0.2 \mathrm{~m} / \mathrm{yr}$ ). At Kapaa, erosion rates as high as $-0.9 \mathrm{~m} / \mathrm{yr}$ were found along a short extent (transects 493-500) where beach appeared intermittently and was ultimately lost to erosion (coastal armoring). A rate from this area is not reported as a regional maximum due to low confidence (high uncertainty) with these results. The maximum long-term accretion rate $(0.7 \pm 0.4 \mathrm{~m} / \mathrm{yr})$ was measured at Anahola Beach, south of Anahola River (table 6). This area is affected by the river discharge and is dynamic (Makai Ocean Engineering and Sea Engineering, 1991). All subregions of East Kauai are erosional in the long and short term (table 7). The Kapaa subregion is the most erosional of the three, with an average long-term rate of $-0.17 \pm 0.02$ and an average short-term rate of $-0.08 \pm 0.02 \mathrm{~m} / \mathrm{yr}$.

The average short-term shoreline change rate for East Kauai is $-0.06 \pm 0.02 \mathrm{~m} / \mathrm{yr}$. Sixty-three percent of the shortterm rates are erosional, the highest percentage for the four Kauai regions (table 5). East Kauai has the lowest percentage of accretional rates in the short term (33 percent) among the four Kauai regions. The maximum short-term erosion rate $(-1.6 \pm 0.3 \mathrm{~m} / \mathrm{yr})$ was measured in Anahola, north of Kuaehu Point (table 6), adjacent to a stone revetment. The maximum short-term accretion rate $(1.1 \pm 0.6 \mathrm{~m} / \mathrm{yr})$ was measured at the same location as the maximum long-term accretion rate (south of Anahola River).

Along the coast, long-term and short-term rates followed similar trends to each other (fig. 17). The long- and short-term confidence bands for Lae Lipoa are relatively wide because rates were calculated from only three to four shorelines.

\section{South Kauai}

Kauai's southern coast is exposed to Kona storm waves, trade wind waves, and southern swell. Longshore currents transport sediment westward from the mouths of large rivers (for example, Hanapepe Stream) (Fierstein and Fletcher, 2004). Hurricane Iwa (1982) and Hurricane Iniki (1992) devastated this area, which was inundated as far as $300 \mathrm{~m}$ inland at Poipu (Fletcher and others, 2002).

The Waimea subregion lacks a shallow near-shore reef and has a wide, steep beach with a high proportion 


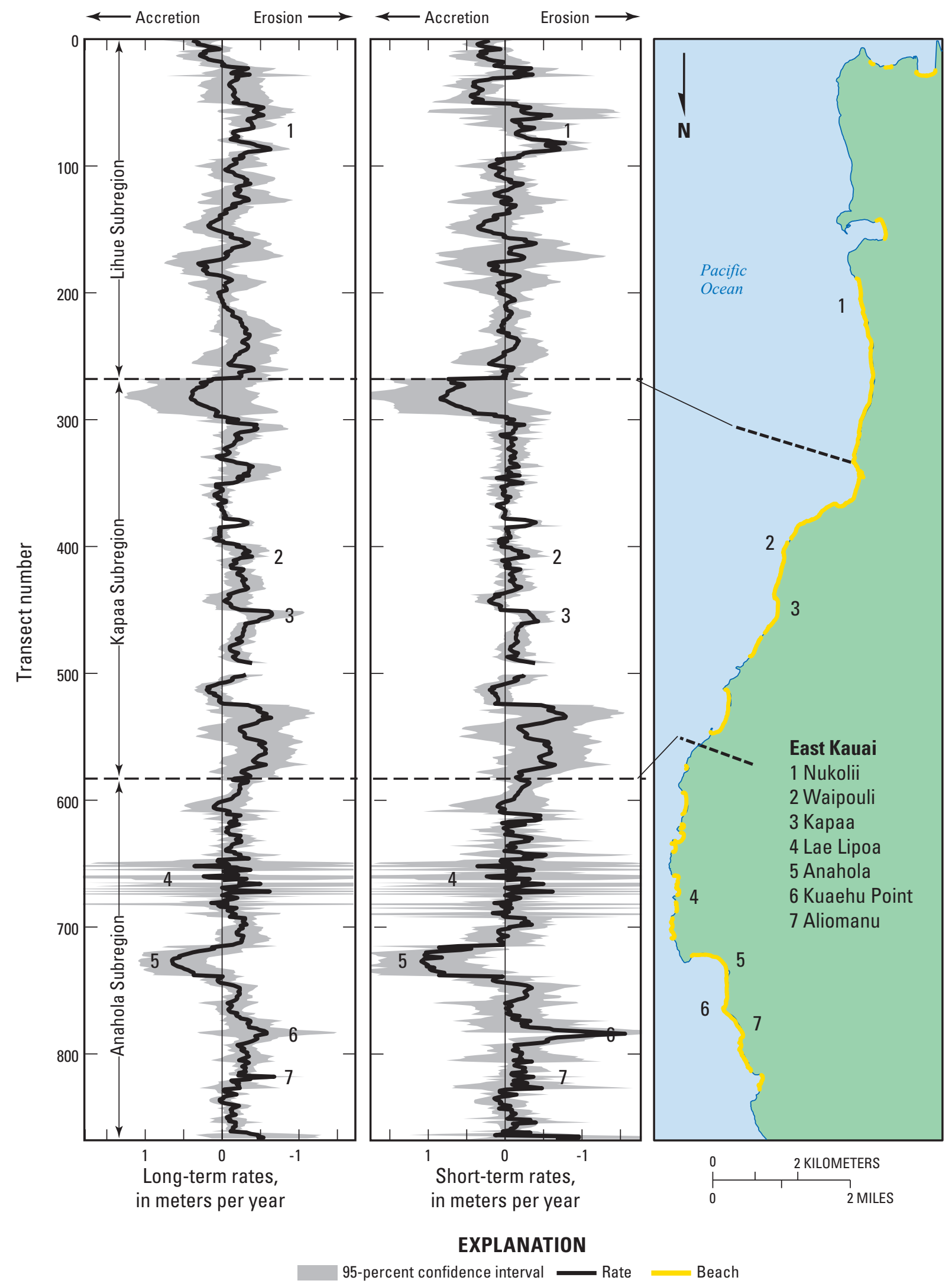

Figure 17. Long-term (all available years) and short-term (1940s to present) shoreline change rates, East Kauai. (Location shown in figure 15) 
of terrigenous sediment (relative to typical calcareous Hawaiian beaches) from the Waimea River. The west end of the Hanapepe subregion is composed of narrow, gently sloping, calcareous beach. The remainder of the Hanapepe and the Poipu subregions is composed of rejuvenated volcanic basalt with calcareous pocket beaches and fringing reef. The Mahaulepu subregion contains lithified sand dunes (fig. 18) (Makai Ocean Engineering and Sea Engineering, 1991; Fierstein and Fletcher, 2004).

Summary statistics for South Kauai conflict in that average long- and short-term rates indicate approximately stable to accreting shorelines, whereas percentages of erosional and accretional transects indicate a predominance of erosion. The South region is made up of four subregions (fig. 19). From three to eight shorelines, ranging in date from 1926 to 2007 , are available for the South region of Kauai (table 4). For the 790 transects, 28 percent of the short-term rates and 32 percent of the long-term rates are significant (fig. 19).

The average long-term shoreline change rate for South Kauai is approximately stable at $-0.01 \pm 0.02 \mathrm{~m} / \mathrm{yr}$ (table 5). Sixty-three percent of transects are erosional in the long term. The maximum long-term erosion rate $(-1.5 \pm 0.4 \mathrm{~m} / \mathrm{yr})$ was found at a small pocket beach north of Koki Point (table 6) where most of the remaining beach is now perched on a rock bench or has disappeared. Other locations with significant long-term erosion rates include Salt Pond (up to $-0.8 \pm$ $0.5 \mathrm{~m} / \mathrm{yr}$ ), Poipu (up to $-0.3 \pm 0.1$ ), Shipwreck (up to $-0.7 \pm$ $0.4 \mathrm{~m} / \mathrm{yr}$ ), and Mahaulepu (up to $-0.5 \pm 0.4$ ). The maximum long-term accretion rate $(1.4 \pm 0.7 \mathrm{~m} / \mathrm{yr})$ was measured at Waimea, east of Kikiaola Harbor (table 6, fig. 19). The beach on the western side of the harbor (Oomano) showed the highest erosion rate in the West Kauai region (see West Kauai, fig. 21). The harbor, built in 1959, disrupts alongshore transport of sand and acts as a groin, impounding sand on the Waimea (eastern) side and preventing sand from nourishing the beach at Oomano (Makai Ocean Engineering and Sea Engineering, 1991).

Unlike the long-term average shoreline change rate, the short-term rate of $0.05 \pm 0.04 \mathrm{~m} / \mathrm{yr}$ suggests an overall trend of accretion along South Kauai (table 5). However, the beach is erosional at 57 percent of transects in the short term, suggesting an overall trend of erosion. The maximum short-term erosion rate $(-1.7 \pm 9.9 \mathrm{~m} / \mathrm{yr})$ was found at the end of a pocket beach in Lawai Bay (table 6, fig. 19), where an overall trend of erosion in the bay has resulted in loss of the beach at the eastern end of the bay prior to 1984. The high degree of uncertainty associated with this rate is a result of using truncated data (three shorelines) to calculate a rate in an area of beach loss. The maximum short-term accretion rate $(1.7 \pm 0.3 \mathrm{~m} / \mathrm{yr})$ was measured at the same position as the maximum long-term rate (Waimea - east of Kikiaola Small Boat Harbor). Longterm and short-term rates follow similar trends along the South Kauai coast (fig. 19), though, rates are less erosive in the short term as indicated by average rates and percentages of eroding and accreting transects (table 5).

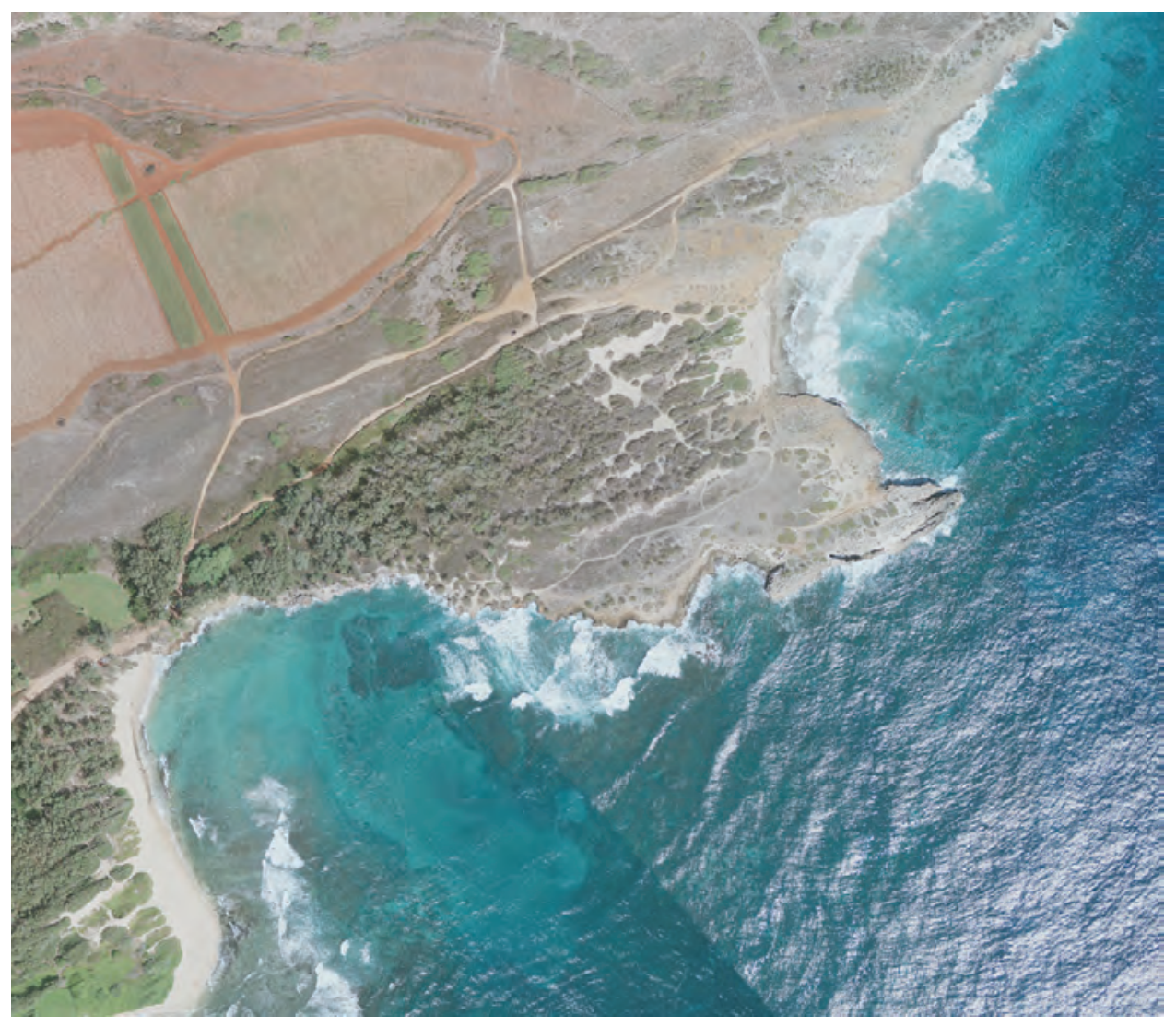

Figure 18. Eolianite headland (lithified carbonate sand dunes), Mahaulepu, South Kauai. (Location shown in figure 19) (Photograph by Hawaii Aviation, Inc.) 

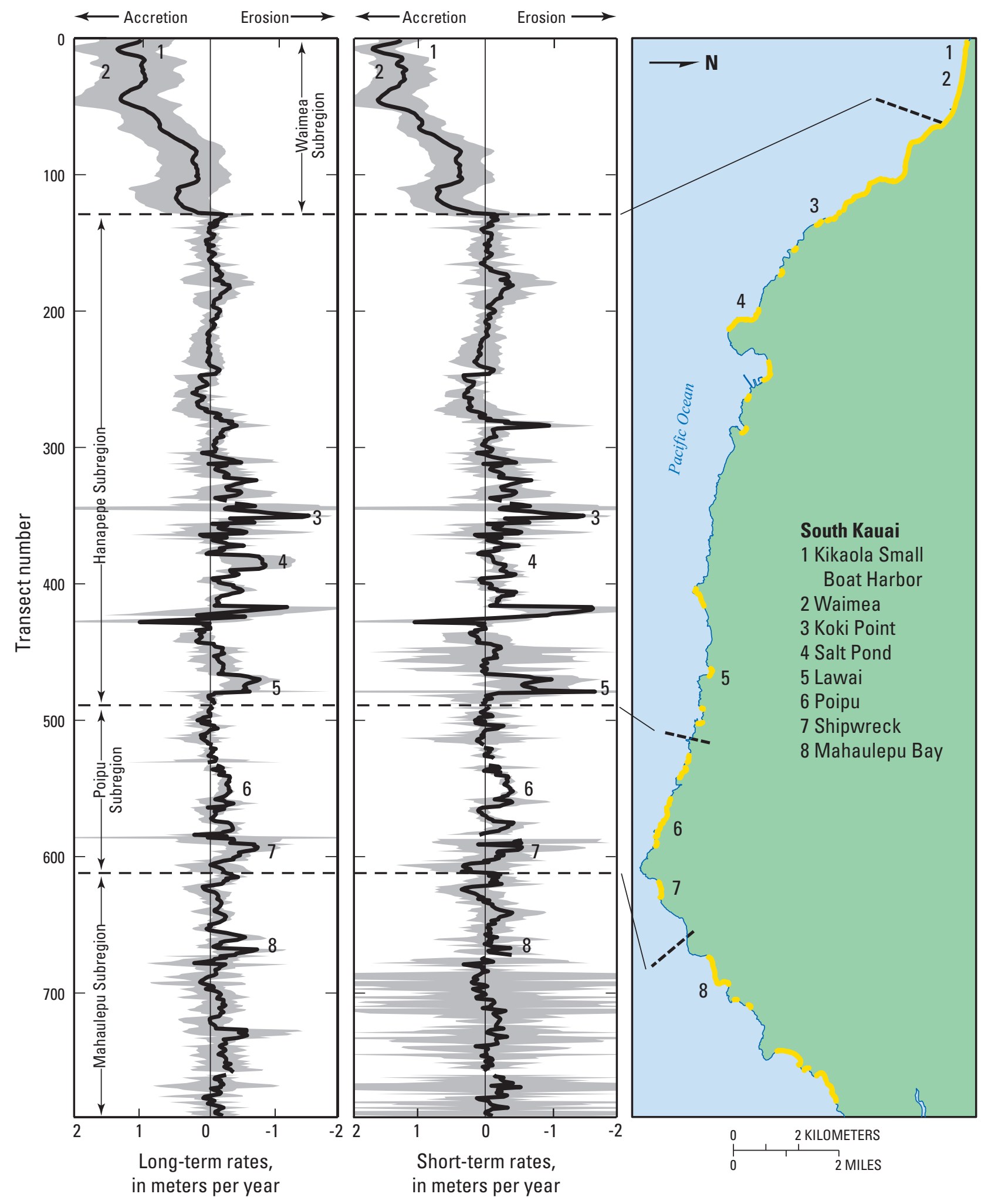

EXPLANATION

95-percent confidence interval Rate Beach

Figure 19. Long-term (all available years) and short-term (1940s to present) shoreline change rates, South Kauai. (Location shown in figure 15) 


\section{West Kauai}

Kauai's western coast is located on the Mana coastal plain, and is characterized by gently sloping beaches. The Mana Plain extends $5 \mathrm{~km}$ inland and is the product of converging longshore sediment transport from the north and southeast. The sediment transport from the north is driven by North Pacific swell and trade winds in winter; the transport from the southeast is driven by summer southern swell and trade winds (Moberly, 1968). The shoreline is composed of calcareous sand with outcrops of beach rock. Most of the beaches in this area are wide and backed by an extensive sand dune system (fig. 20).

As a whole, West Kauai is erosional in the long term and accretional in the short term (table 5). The West region is divided into three subregions (fig. 21). Shoreline change analysis for West Kauai was based on from three to nine shorelines ranging from 1926 to 2006 (table 4). Only 12 and 13 percent of transects indicate significant rates in the long term and short term, respectively (fig. 21). Rates are significant for only a few isolated transects outside the Oomano subregion. West Kauai is exposed to refracted swells from the north in winter and from the south in summer. The seasonal shift in predominant wave direction results in high seasonal variability in shoreline position (noise), which is likely responsible for the low percentage of significant rates along West Kauai.

The average long-term rate in this region is erosional at $-0.13 \pm 0.04 \mathrm{~m} / \mathrm{yr}$, and 64 percent of transects are erosional in the long term (table 5). Average long-term rates in all subregions are erosional (table 7). The Oomano subregion is the most erosional, with an average rate of $-0.64 \pm$ $0.03 \mathrm{~m} / \mathrm{yr}$. The maximum long-term erosion rate $(-1.4 \pm$ $0.2 \mathrm{~m} / \mathrm{yr}$ ) was measured at Oomano, just west of Kikiaola Small Boat Harbor (table 6, fig. 21). As discussed in the section on the South Kauai region, the harbor blocks sediment transport from Waimea to the east that otherwise would nourish Oomano Beach. The maximum accretion rate $(1.6 \pm$ $1.8 \mathrm{~m} / \mathrm{yr}$ ) was found in Majors Bay at the shorefront of the Pacific Missile Range. This segment of beach experiences large seasonal fluctuations in shoreline position, resulting in high rate uncertainty.

In contrast to long-term shoreline change analysis, short-term analysis at West Kauai indicates an overall trend of accretion. The average of all short-term rates is accretional at $0.16 \pm 0.08 \mathrm{~m} / \mathrm{yr}$ (table 5). Roughly the same percentage of transects is accretional (49 percent) as erosional (48 percent). The maximum short-term erosion rate $(-1.5 \pm 0.3 \mathrm{~m} / \mathrm{yr})$ was measured at the same transect as the maximum long-term

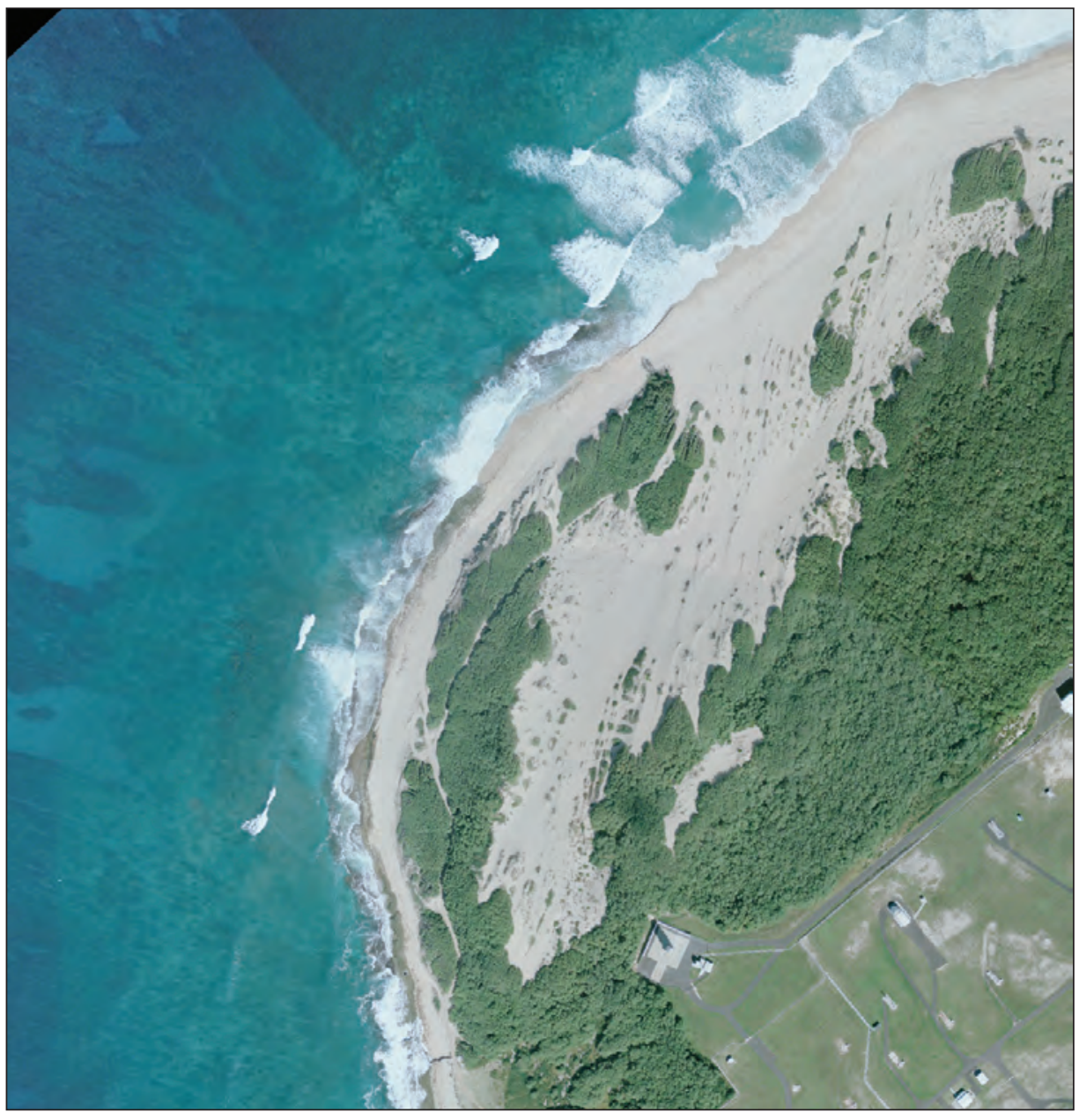

Figure 20. Dunes at the west end of the Mana coastal plain, West Kauai. (Location shown in figure 21) (Photograph by Hawaii Aviation, Inc.) 


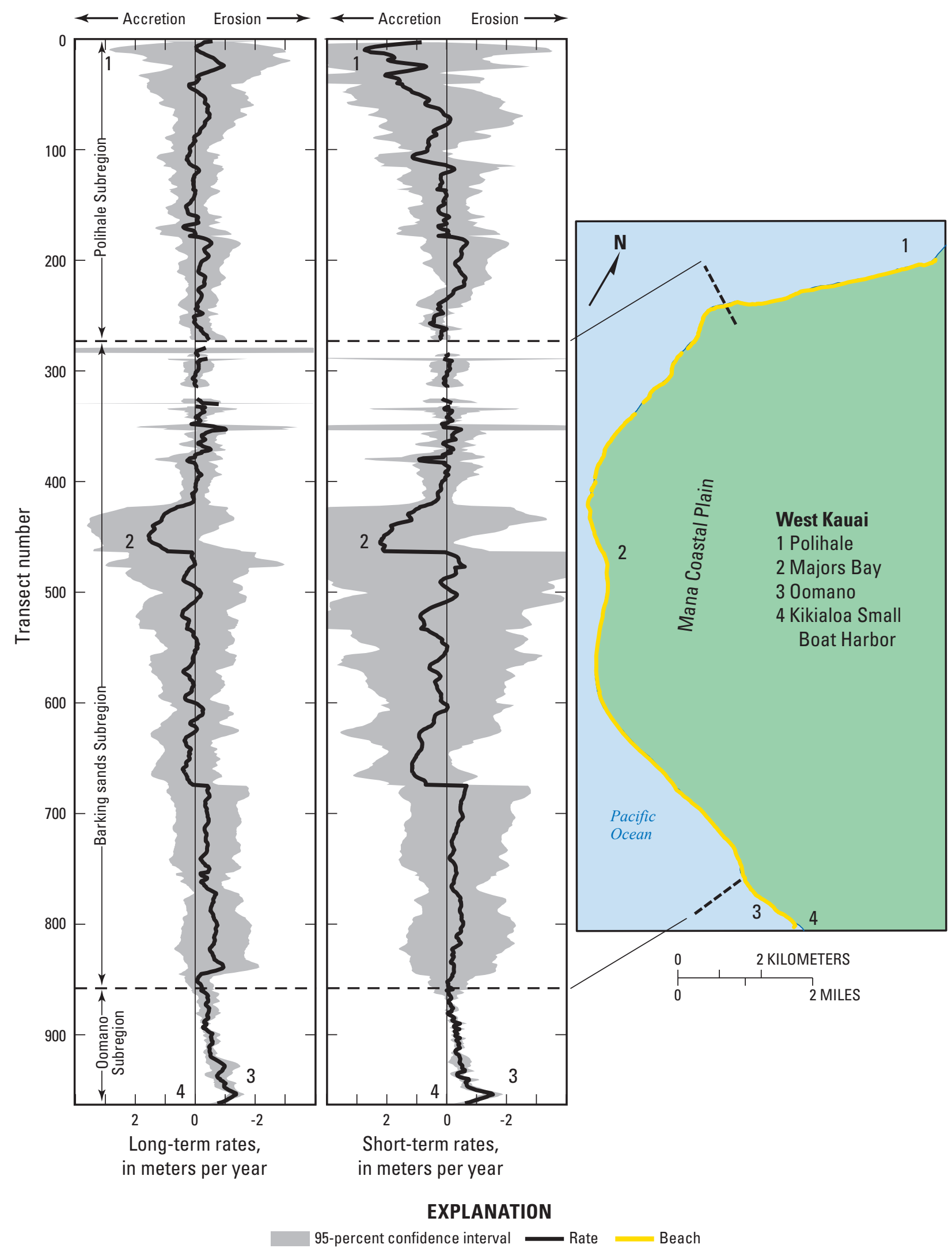

Figure 21. Long-term (all available years) and short-term (1940s to present) shoreline change rates, West Kauai. (Location shown in figure 15) 
erosion rate (Oomano, just west of the harbor). The maximum short-term accretion rate $(2.8 \pm 6.2 \mathrm{~m} / \mathrm{yr})$ was measured at the northern end of Polihale (table 6), which is exposed to the full energy of large winter waves, resulting in seasonal fluctuations in shoreline position.

The alongshore pattern of variability of short-term shoreline change rates is similar to the pattern of long-term rates throughout most of West Kauai, with the exception of the north half of the Polihale subregion (fig. 21). However, the three subregions are significantly less erosional between the long term and short-term rates (table 7). The Polihale subregion is erosional in the long term with an average rate $-0.14 \pm 0.07 \mathrm{~m} / \mathrm{yr}$ but accretional in the short term at $0.37 \pm$ $0.11 \mathrm{~m} / \mathrm{yr}$. Similarly, Barking Sands is stable to erosional in the long term with an average rate $-0.04 \pm 0.06 \mathrm{~m} / \mathrm{yr}$ but accretional in the short term at $0.18 \pm 0.11 \mathrm{~m} / \mathrm{yr}$. Oomano is significantly erosional in the long and short-term shoreline change. Though, the average rate is somewhat reduced in the short term compared to the long term $(-0.44 \pm 0.02 \mathrm{~m} / \mathrm{yr}$ compared to $-0.64 \pm 0.03 \mathrm{~m} / \mathrm{yr}$ ). Other than those at Oomano, few rates at individual transects along West Kauai are significant due to high short-term (seasonal to decadal) variability in shoreline position.

\section{Oahu}

Oahu is the third largest and most populated island of the Hawaiian chain. Oahu is made up of eroded remnants of two shield volcanoes (Waianae Range and Koolau Range, fig. 22) separated by the central Schofield Plateau (Macdonald and others, 1986). Explosive eruptions from the Honolulu Volcanic Series created several of the headlands on the southern-southeastern side of the island, including Diamond Head, Koko Head, and Mokapu Point. Emerged carbonate reefs formed under higher sea levels in the late Pleistocene Epoch compose many of the smaller headlands and underlie much of the coastal plain around the island. Oahu has approximately $107 \mathrm{~km}$ of sandy beach that is separated into four regions: north, east, south, and west.

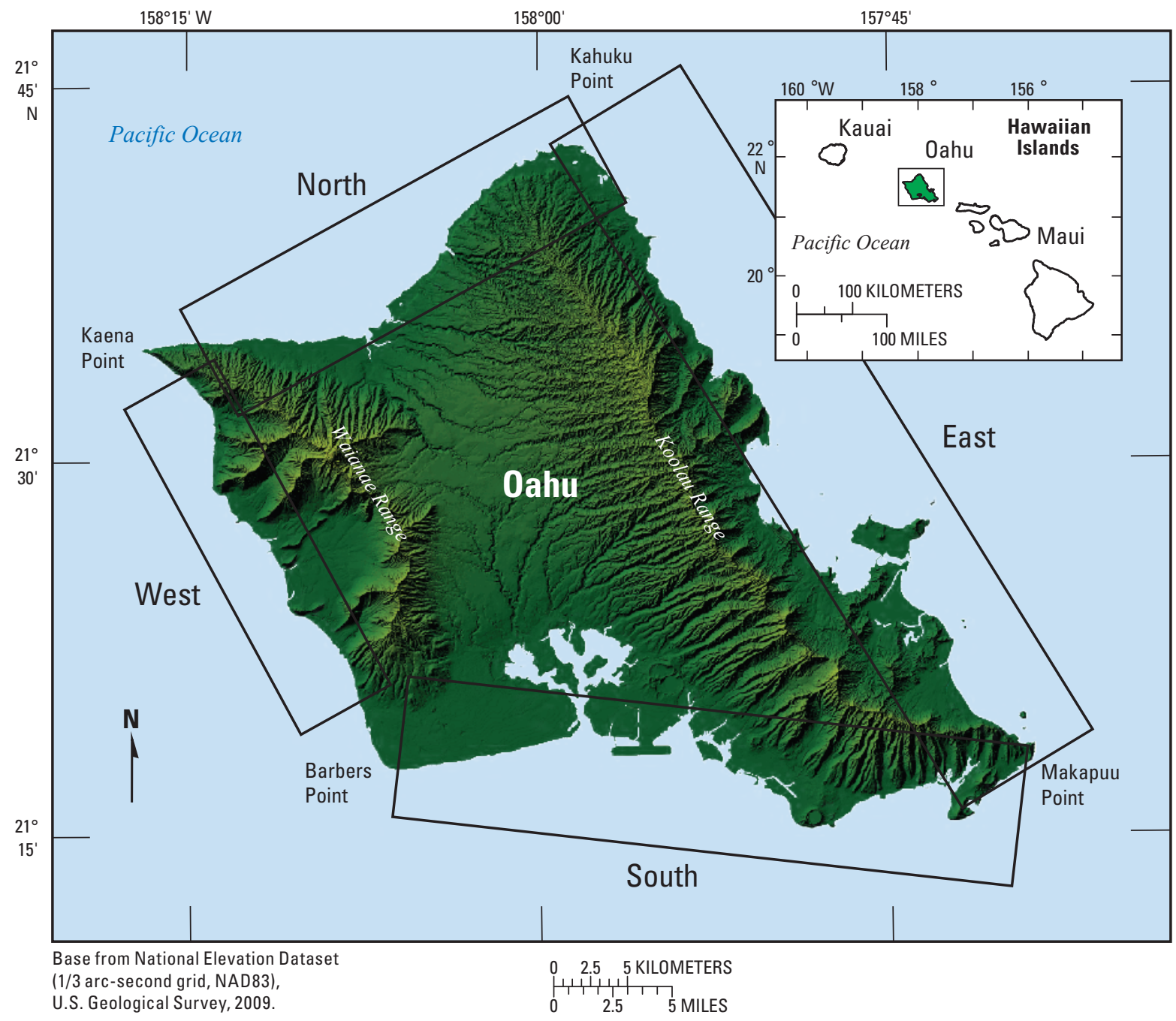

Figure 22. Four regions of Oahu: north, east, south, and west. 
A maximum of 12 high-quality historical shorelines, ranging from 1910 to 2007, are available for Oahu (table 8). The earliest shoreline is derived from a 1910 or 1927 T-sheet or 1928 aerial photograph. A 1932-33 shoreline from a T-sheet is also included for some study areas. All other shorelines are derived from vertical aerial photographs taken from 1928 to 2007.

Erosion is the general long- and short-term trend of Oahu beaches (table 5). Approximately $9 \mathrm{~km}$ or 8 percent of the total length of beach analyzed was completely lost to erosion in the analysis period. The average of long-term rates for Oahu is erosional at $-0.06 \pm 0.01 \mathrm{~m} / \mathrm{yr}$. The average short-term rate is roughly the same as the long-term average rate at $-0.05 \pm$ $0.01 \mathrm{~m} / \mathrm{yr}$ (table 5). Erosion is occurring in the long and short term at the majority of transects ( 60 and 58 percent, respectively). The maximum long- and short-term erosion rates on Oahu were found at Kualoa Point in East Oahu $(-1.8 \pm 0.3$ and $-1.9 \pm 0.9 \mathrm{~m} / \mathrm{yr}$, respectively; table 9$)$. The maximum long- and short-term accretion rates were found at Pokai Bay in West Oahu $(1.7 \pm 0.6 \mathrm{~m} / \mathrm{yr})$. The longand short-term rates at Pokai are equal because they were calculated using a truncated data set (1967-2007) following the construction of harbor breakwalls. The long-term rates at Kualoa and Pokai are the highest in the three islands.

Table 8. Number and range in years of historical shorelines for long- and short-term shoreline change analysis on Oahu.

\begin{tabular}{lccccc}
\hline \multirow{2}{*}{ Region } & \multicolumn{2}{c}{ Long-term $^{n}$} & & \multicolumn{2}{c}{ Short-term } \\
\cline { 2 - 3 } \cline { 2 - 3 } \cline { 5 - 6 } & Number of shorelines $^{1}$ & Range in years $^{\mathbf{1}}$ & & Number of shorelines $^{\mathbf{1}}$ & Range in years $^{\mathbf{1}}$ \\
\hline North & $5-11$ & $1910-2007$ & & $5-8$ & $1949-2007$ \\
East & $4-12$ & $1910-2006$ & & $3-10$ & $1949-2006$ \\
South & $3-10$ & $1927-2005$ & & $3-9$ & $1949-2005$ \\
West & $6-12$ & $1910-2007$ & & $5-9$ & $1949-2007$ \\
\hline
\end{tabular}

'Number of shorelines and range in years vary in each region.

Table 9. Maximum shoreline change rates on Oahu.

[m/yr, meters per year; max., maximum; \pm , plus or minus]

\begin{tabular}{|c|c|c|c|c|}
\hline Region & $\begin{array}{c}\text { Long-term rate } \\
(\mathrm{m} / \mathrm{yr})\end{array}$ & Location ${ }^{1}$ & $\begin{array}{c}\text { Short-term rate } \\
(\mathrm{m} / \mathrm{yr})\end{array}$ & Location ${ }^{1}$ \\
\hline \multicolumn{5}{|c|}{ North } \\
\hline Max. accretion & $0.8 \pm 0.8$ & Rocky Point, high seasonal change & $1.1 \pm 0.9$ & Rocky Point, high seasonal change \\
\hline \multicolumn{5}{|c|}{$\begin{array}{ll}\text { East } \\
\end{array}$} \\
\hline \multicolumn{5}{|c|}{ South } \\
\hline Max. erosion & $-1.6 \pm 2.7$ & West side Natatorium, beach lost & $-1.6 \pm 2.7$ & West side Natatorium, beach lost \\
\hline Max. accretion & $0.8 \pm 0.2$ & Kaimana, south side Natatorium & $0.9 \pm 0.3$ & Kaimana, east side Natatorium \\
\hline \multicolumn{5}{|c|}{ West } \\
\hline
\end{tabular}

${ }^{1}$ Locations shown in figures 24, 26, 29, and 30.

${ }^{2}$ Maximum erosion or accretion for all three islands (Kauai, Oahu, and Maui).

${ }^{3}$ Maximum erosion or accretion for Oahu. 


\section{North Oahu}

Oahu's north shore is seasonally dynamic. This region is exposed to the strong winter North Pacific swell that causes steepening of the foreshore and narrowing of the beaches. During relatively calm summer conditions, the beaches are flat and wide (Hwang, 1981). A fringing reef of variable width and depth is present offshore. The coastal plain is variable in width and is composed largely of fossiliferous limestone and unconsolidated sand. Outcrops of calcareous eolianite and reefrock form many of the short headlands in this region, including those at Puaena Point, Sharks Cove, Kawela Bay, Kuilima (Turtle Bay), and Kahuku Point (fig. 23).

The North region is divided into two subregions: Sunset and Mokuleia (fig. 24). The Sunset subregion extends from Kahuku Point at the northern tip of the island to Haleiwa. A continuous 6-km-long beach extends from Waialee to Ke Iki. The remainder of the beaches in the Sunset subregion are in pockets between rocky headlands. The Mokuleia subregion is between Kaiaka Bay and Camp Erdman. Mokuleia Beach is a continuous 12-km-long beach extending from Waialua to Camp Erdman.

Twenty-four percent of the short-term rates and 31 percent of the long-term rates at the 1,287 transects along North Oahu are significant - the lowest percentages in the four Oahu regions (fig. 24). The percentage of rates in this region that is significant is low as a result of high seasonal variability (noise) in shoreline position. Large winter swells cause variations in beach width by up to two thirds. The rates at some North Oahu beaches are also unreliable as a result of poor seasonal

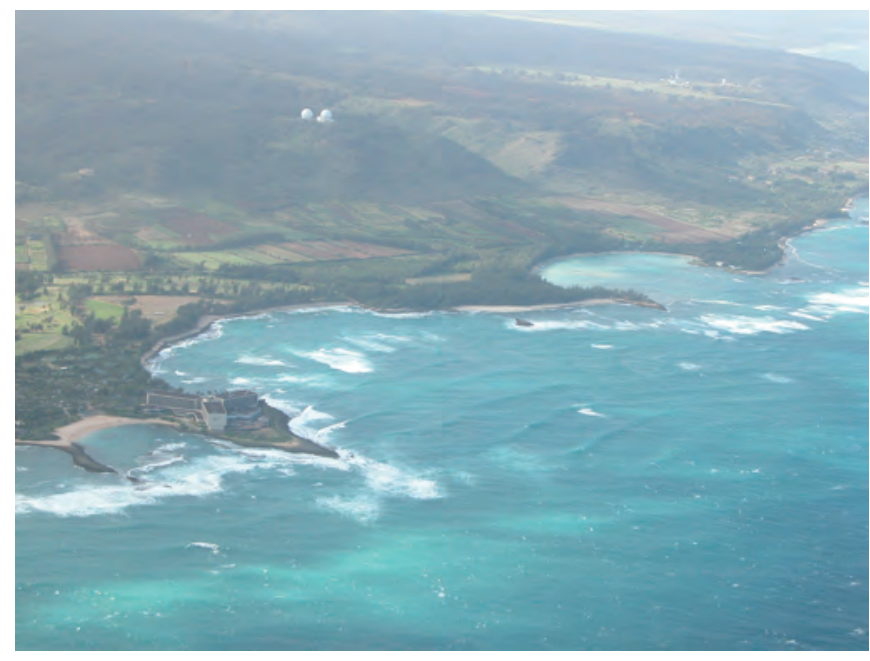

Figure 23. Limestone headlands at Kahuku Point and Kuilima (Turtle Bay), North Oahu. (Locations shown in figure 24) (Photograph by Andrew D. Short, University of Sydney) distribution of the available aerial photographs. For example, along much of the Sunset subregion the most recent historical shorelines (1996 and 2005) are from summer months, whereas earlier air photo shorelines are from winter or spring months. The overall trend of North Oahu beaches is erosion (table 5). The average long- and short-term rates on the northern shore are erosional at $-0.11 \pm 0.01$ and $-0.07 \pm 0.01 \mathrm{~m} / \mathrm{yr}$, respectively. Seventy-three percent of the total extent of North Oahu beaches is eroding in the long term and 68 percent is eroding in the short term. The two subregions of North Oahu (Sunset and Mokuleia) have an overall trend of long- and short-term erosion, as indicated by average rates (table 10).

The maximum long-term erosion rate $(-1.3 \pm$ $0.8 \mathrm{~m} / \mathrm{yr}$, table 9) was found at Haleiwa Beach Park at a segment of shoreline behind a small breakwater where the beach has been lost. This beach has undergone substantial modification throughout its history, including construction of a groin, breakwater, and sea wall and two beach nourishment projects (Hwang, 1981; Sea Engineering, Inc., 1988). Other areas with significant erosion rates include Kuilima (up to $-0.4 \pm 0.2 \mathrm{~m} / \mathrm{yr}$ ), Waimea (up to $-0.8 \pm 0.4 \mathrm{~m} / \mathrm{yr}$, as a result of sand mining), and Mokuleia (up to $-0.6 \pm 0.1 \mathrm{~m} / \mathrm{yr}$ ). The maximum long-term accretion rate $(0.8 \pm 0.8 \mathrm{~m} / \mathrm{yr})$ was measured at Rocky Point in the Sunset subregion, though this rate is likely affected by seasonal variability and/or bias toward two summer shorelines at the end of the analysis period. The only notable exception to the overall trend of erosion along Mokuleia Beach was found at an accreting cusp along the beach at Waialua with rates up to $0.8 \pm 0.2 \mathrm{~m} / \mathrm{yr}$.

The maximum and minimum short-term change rates were found at the same locations as the long-term maximum and minimum. Long- and short-term rates follow similar trends, with increasing uncertainty in the short-term rates as a result of a shortened data set (fewer shorelines) and high seasonal variability (fig. 24).

\section{East Oahu}

Oahu's eastern coast faces into the predominant easterly trade winds. As a result, the shoreline is exposed to shortperiod trade wind waves year round. Large refracted North Pacific swells also affect this coast on occasion in winter. The coast is mostly a low-lying plain and is moderately to highly developed, with the densest development in the southeast, around Kailua and Lanikai (fig. 25).

Shallow fringing reef that lines much of East Oahu protects the shoreline from the full energy of large waves. However, beaches that back shallow protective reefs are typically low and narrow and are prone to inundation during large waves and storms. Even low rates of chronic erosion have led to beach loss along portions of these narrow beaches. Seawalls have been constructed along much of the coast to protect homes and the coastal highway, and contribute to beach loss in many areas. East Oahu is divided into two subregions, Northeast and Southeast, separated by Kaneohe Bay. The back-bay shoreline of Kaneohe Bay was not included in this study. 


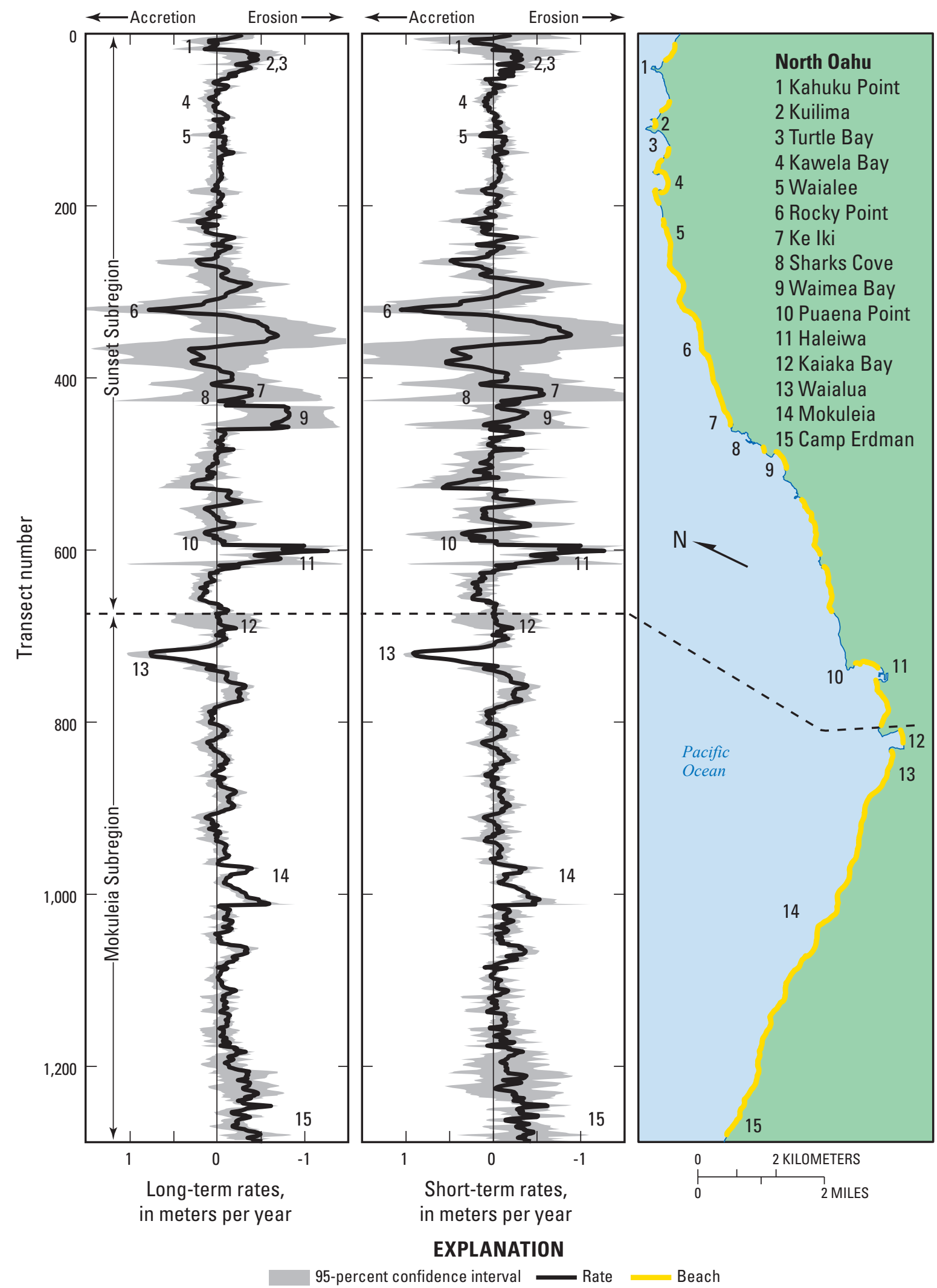

Figure 24. Long-term (all available years) and short-term (1940s to present) shoreline change rates, North Oahu. (Location shown in figure 22) 
Table 10. Average shoreline change rates for Oahu subregions.

[m/yr, meters per year; \pm , plus or minus]

\begin{tabular}{|c|c|c|c|c|}
\hline \multirow{2}{*}{ Region } & \multirow{2}{*}{ Subregion } & \multirow{2}{*}{$\begin{array}{c}\text { Number of } \\
\text { transects }\end{array}$} & \multicolumn{2}{|c|}{ Average rate $(\mathrm{m} / \mathrm{yr})$} \\
\hline & & & Long-term & Short-term \\
\hline \multirow{2}{*}{ North } & Sunset & 673 & $-0.10 \pm 0.02$ & $-0.04 \pm 0.02$ \\
\hline & Mokuleia & 614 & $-0.12 \pm 0.01$ & $-0.11 \pm 0.01$ \\
\hline \multirow{2}{*}{ East } & Northeast & 1,245 & $-0.07 \pm 0.01$ & $-0.09 \pm 0.02$ \\
\hline & Southeast & 863 & $0.12 \pm 0.01$ & $0.09 \pm 0.02$ \\
\hline \multirow{4}{*}{ South } & Ewa & 499 & $-0.06 \pm 0.01$ & $-0.03 \pm 0.01$ \\
\hline & Honolulu & 376 & $-0.05 \pm 0.02$ & $-0.05 \pm 0.02$ \\
\hline & Maunalua & 394 & $-0.02 \pm 0.02$ & $-0.01 \pm 0.05$ \\
\hline & Kaiwi & 50 & $-0.02 \pm 0.03$ & $-0.06 \pm 0.04$ \\
\hline \multirow{3}{*}{ West } & Makua & 174 & $-0.28 \pm 0.03$ & $-0.08 \pm 0.06$ \\
\hline & Waianae & 264 & $-0.25 \pm 0.02$ & $-0.09 \pm 0.02$ \\
\hline & Nanakuli & 190 & $-0.21 \pm 0.02$ & $-0.24 \pm 0.02$ \\
\hline
\end{tabular}

Overall, the beaches of East Oahu are approximately stable to slightly erosional as indicated by average long- and short-term rates and percentages of transects indicating erosion or accretion. East Oahu beaches have from 5 to 12 shorelines with a date range from 1910 to 2006 (table 8). Statistically significant shoreline change rates are found at 35 percent of the East Oahu transects in the long-term rates and 24 percent of the transects in the short-term rates (fig. 26).

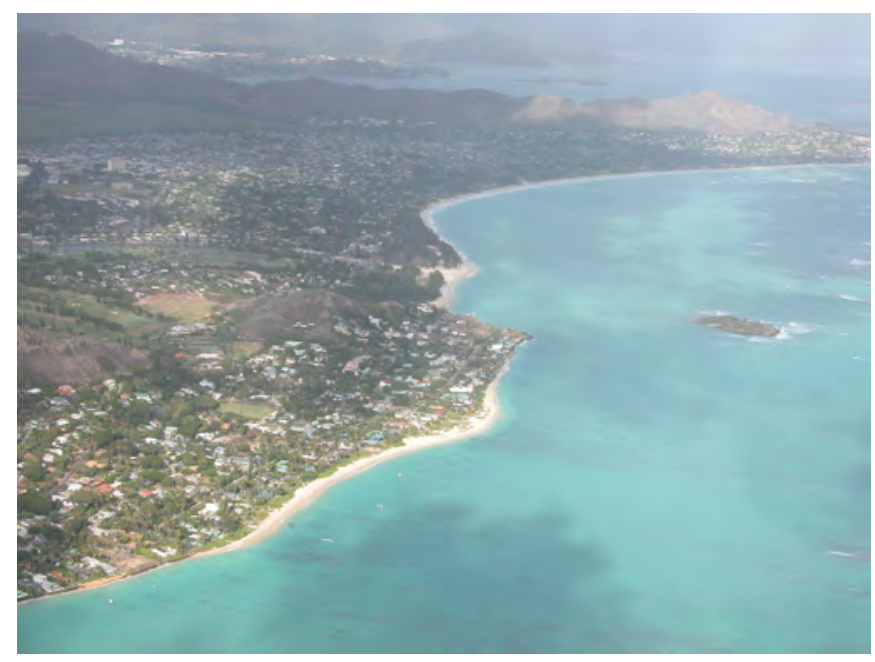

Figure 25. Lanikai (foreground) and Kailua Beaches, East Oahu. (Location shown in figure 26) (Photograph by Andrew D. Short, University of Sydney)
The average long-term rate for East Oahu beaches is roughly stable at $0.01 \pm 0.01 \mathrm{~m} / \mathrm{yr}$ (table 5). Erosion is occurring at 50 percent of transects and accretion is occurring at 47 percent. The maximum and minimum erosion rates were found within a few hundred meters of each other at Kualoa at the northern end of Kaneohe Bay (table 9). The shoreline at Kualoa Point has retreated more than $100 \mathrm{~m}$ since 1928, with rates as high $-1.8 \pm 0.3 \mathrm{~m} / \mathrm{yr}$. Eroded sand is transported around Kualoa Point to the west, where it is deposited inside the bay, forming a spit that is accreting at $1.5 \pm 0.4 \mathrm{~m} / \mathrm{yr}$ - the maximum long-term accretion rate in the East Oahu region. Other locations with significant erosion rates include Kahuku Beach (up to $-1.2 \pm 0.6 \mathrm{~m} / \mathrm{yr}$, as a result of sand mining, fig. 27), Laniloa (up to $-0.7 \pm 0.2 \mathrm{~m} / \mathrm{yr}$ ), Hauula (up to $-0.3 \pm$ $0.1 \mathrm{~m} / \mathrm{yr}$ ), Makalii Point (up to $-0.3 \pm 0.2 \mathrm{~m} / \mathrm{yr}$, beach lost to erosion), Kaaawa (up to $-0.3 \pm 0.1 \mathrm{~m} / \mathrm{yr}$ ), and Bellows (up to $-0.6 \pm 0.3 \mathrm{~m} / \mathrm{yr})$.

Some of the longest extents of accreting shoreline in Hawaii were found along East Oahu. Areas of significant accretion in East Oahu include Laie (up to $0.4 \pm 0.2 \mathrm{~m} / \mathrm{yr}$ ), Kahana (up to $0.7 \pm 0.3 \mathrm{~m} / \mathrm{yr}$ ), Mokapu (up to $0.6 \pm$ $0.5 \mathrm{~m} / \mathrm{yr}$ ), and Kailua (up to $0.7 \pm 0.2 \mathrm{~m} / \mathrm{yr}$ ). The beach at central Lanikai is accreting at up to $0.8 \pm 0.3 \mathrm{~m} / \mathrm{yr}$; however, the beach along the adjacent shoreline to the north and south has been lost to erosion (seawalls) in the last few decades. Most of the accretion along East Oahu is concentrated in the Southeast subregion. The average long- and short-term rates for Northeast Oahu are erosional $(-0.07 \pm 0.01$ and $-0.09 \pm$ $0.02 \mathrm{~m} / \mathrm{yr}$, respectively), whereas the average long- and shortterm rates for Southeast Oahu are accretional $(0.12 \pm 0.01$ and $0.09 \pm 0.02 \mathrm{~m} / \mathrm{yr}$, respectively) (table 10).

The short-term rates follow trends similar to those of the long-term rates (fig. 26). Like the average long-term rate, the average short-term rate is approximately stable at $-0.01 \pm$ $0.01 \mathrm{~m} / \mathrm{yr}$. However, more transects are erosional in the short term than in the long-term rates, with erosion occurring at 54 percent of transects and accretion occurring at 44 percent (table 5). The maximum short-term erosion and accretion rates were also found at Kualoa $(-1.9 \pm 0.9$ and $1.3 \pm 1.8 \mathrm{~m} / \mathrm{yr}$, respectively; table 9).

\section{South Oahu}

Oahu's southern shore is heavily developed on a predominantly low-lying coast, with much of the shoreline lined with hardened structures such as seawalls, revetments, and groins. This shore is exposed to strong trade winds that tend to blow alongshore, and southerly waves from the South Pacific and occasional Kona storms. Tsunamis and hurricanes pose a potential threat to the low-lying coastal plain and dense urban development (Fletcher and others, 2002). With the exception of Diamond Head and Koko Head, the coast is gently sloping with a wide, shallow fringing reef. 


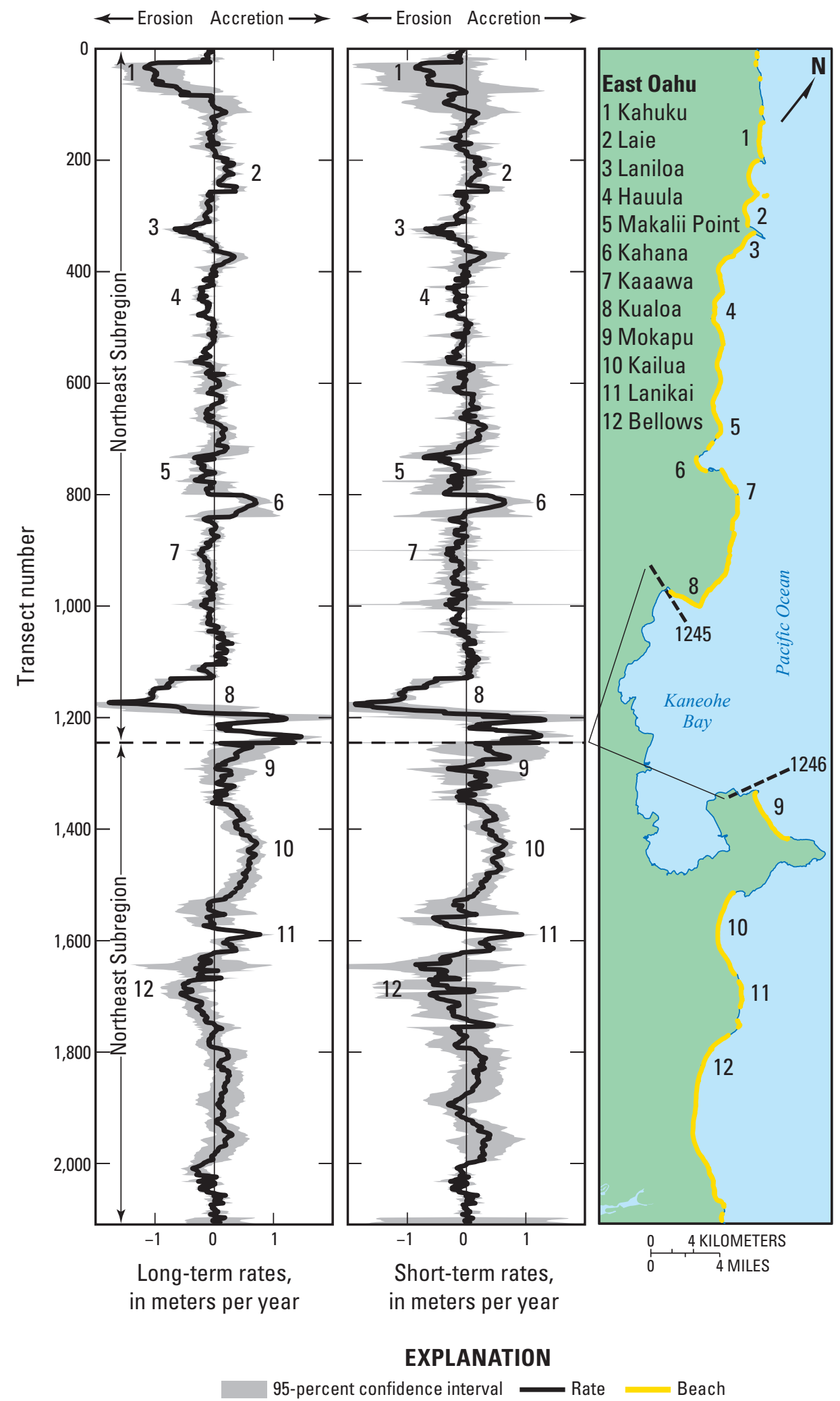

Figure 26. Long-term (all available years) and short-term (1940s to present) shoreline change rates, East Oahu. (Location shown in figure 22) 


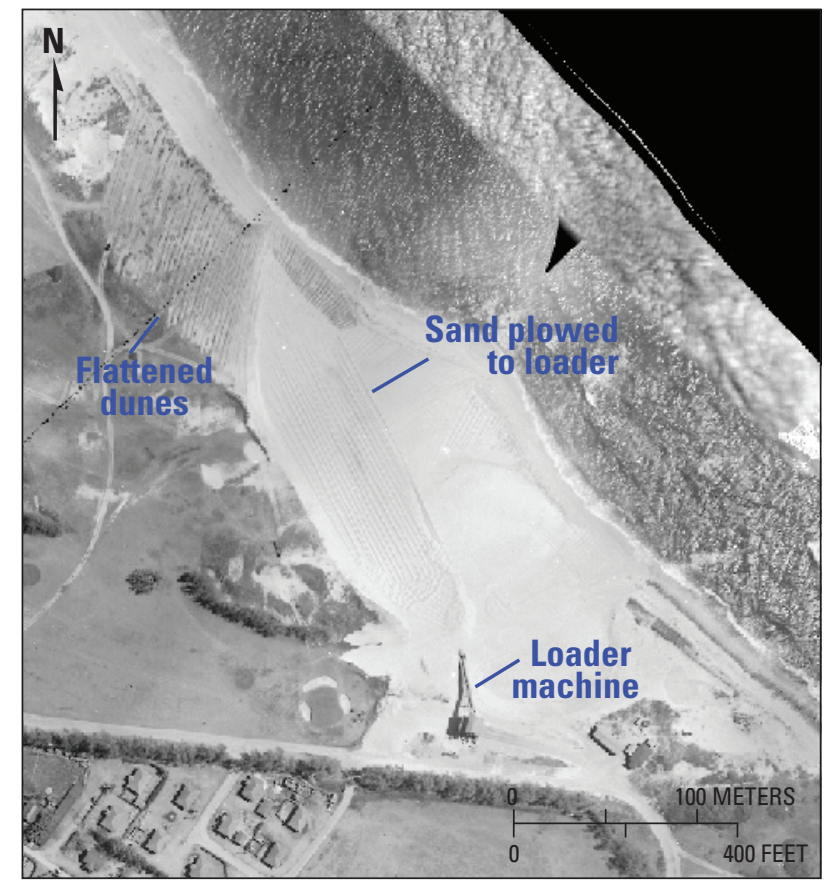

Figure 27. The south end of Kahuku Beach, northeast Oahu, 1949, showing evidence of sand mining. The dunes were flattened, plowed into the surf, and shoveled to the loading machine. The beach width decreased approximately 60 meters from 1949 to 1967. (Location shown in figure 26) (Photograph by R.M. Towill Corporation)

Waikiki is the hub of Hawaii's tourist economy and the health of its beaches is critical to the state economy (Miller and Fletcher, 2003) (fig. 28). Waikiki was originally a wetland with a narrow strip of sandy beach. Development in this region started in the late 1800 s, and the construction of a canal was proposed to divert streams from Waikiki, facilitating additional development. As development increased in the early 20th century, beach erosion became an increasing problem. Seawalls and groins were constructed and beach nourishment projects were pursued to maintain a healthy beach. Beach nourishment has continued into the 21 st century, with the most recent nourishment project occurring in early 2012 (24,000 square yards). There are four subregions along South Oahu: Ewa, Honolulu, Maunalua, and Kaiwi.

From 3 to 10 shorelines from 1927 to 2005 are available for analysis of South Oahu beaches (table 8). At the 1,319 transects, 36 percent of long-term rates and 34 percent of short-term rates are significant (fig. 29). The modern shoreline from Sand Island to Diamond Head (Honolulu subregion) bears little resemblance to the shoreline in its natural condition and is largely the result of engineering efforts (for example, groins, sand fill, and seawalls) intended to widen the beach and move it seaward (Miller and Fletcher, 2003; Wiegel, 2008). As a result of extensive shoreline reconstruction, only historical shorelines for the modern configuration of artificially altered beaches were used to calculate change rates.

The average long-term shoreline change rate in the south $(-0.04 \pm 0.01 \mathrm{~m} / \mathrm{yr})$ and the percentage of eroding transects (50 percent) and accreting transects (48 percent) indicate a slight overall prevalence of erosion (table 5). The Ewa subregion is the most erosional section of South Oahu, with an average long-term rate of $-0.06 \pm 0.01 \mathrm{~m} / \mathrm{yr}$ (table 10). The Honolulu subregion is also eroding in the long term ( -0.05 $\pm 0.02 \mathrm{~m} / \mathrm{yr}$ ). The average long-term rate for the Maunalua subregion is slightly erosional to stable $(-0.02 \pm 0.02 \mathrm{~m} / \mathrm{yr})$.

The maximum long-term erosion rate $(-1.6 \pm 2.7 \mathrm{~m} / \mathrm{yr})$ was found at Queens Beach, Waikiki where the shoreline is hardened and much of the beach disappeared prior to 1975. Erosion up to $-1.6 \pm 0.4 \mathrm{~m} / \mathrm{yr}$ is also occurring at the eastern end of the Ewa subregion near the Pearl Harbor entrance channel (Keahi Point), where erosion of a sandy headland has forced the removal of several homes and prompted construction of a boulder revetment. Other areas with significant long-term erosion rates include Nimitz Beach (up to $-0.3 \pm 0.1 \mathrm{~m} / \mathrm{yr}$ ), Oneula (up to $-0.3 \pm 0.2 \mathrm{~m} / \mathrm{yr}$ ), Sand Island (up to $-0.3 \pm 0.2 \mathrm{~m} / \mathrm{yr}$ ), Ala Moana (up to $-0.8 \pm 0.3 \mathrm{~m} / \mathrm{yr}$ ), Fort DeRussy (up to $-0.8 \pm 0.4 \mathrm{~m} / \mathrm{yr}$ ), and Kahala ( $-0.8 \pm$ $0.7 \mathrm{~m} / \mathrm{yr}$, beach lost). The maximum long-term accretion rate $(0.8 \pm 0.2 \mathrm{~m} / \mathrm{yr})$ was found at Kaimana Beach in Waikiki, on the eastern side of the natatorium. The natatorium walls act as a groin, disrupting the westerly longshore transport of sediment and resulting in accretion on the eastern side of the natatorium (Kaimana) and erosion on the western side (Queens).

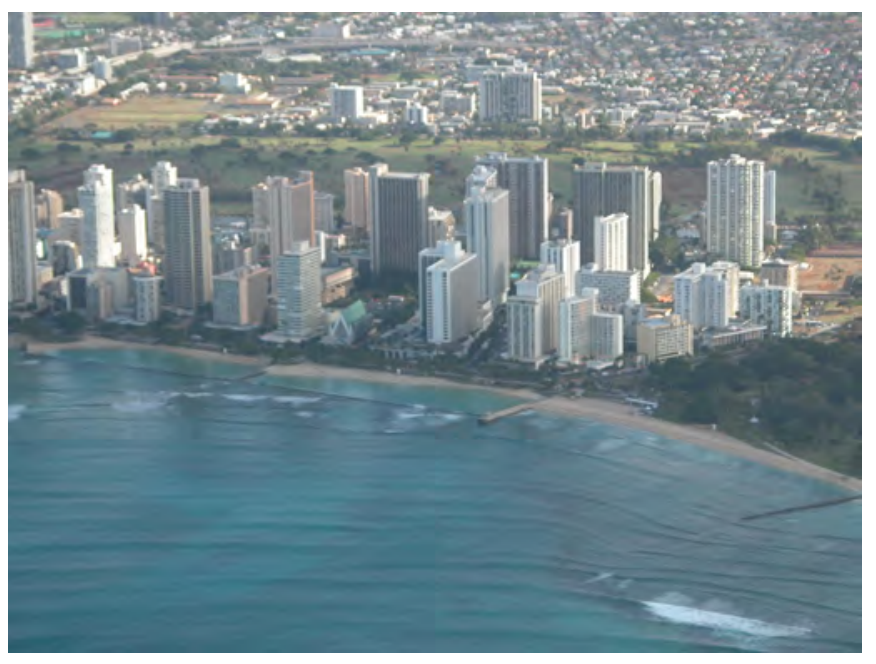

Figure 28. Engineered shoreline at Waikiki, South Oahu. (Location shown in figure 29) (Photograph by Andrew D. Short, University of Sydney) 


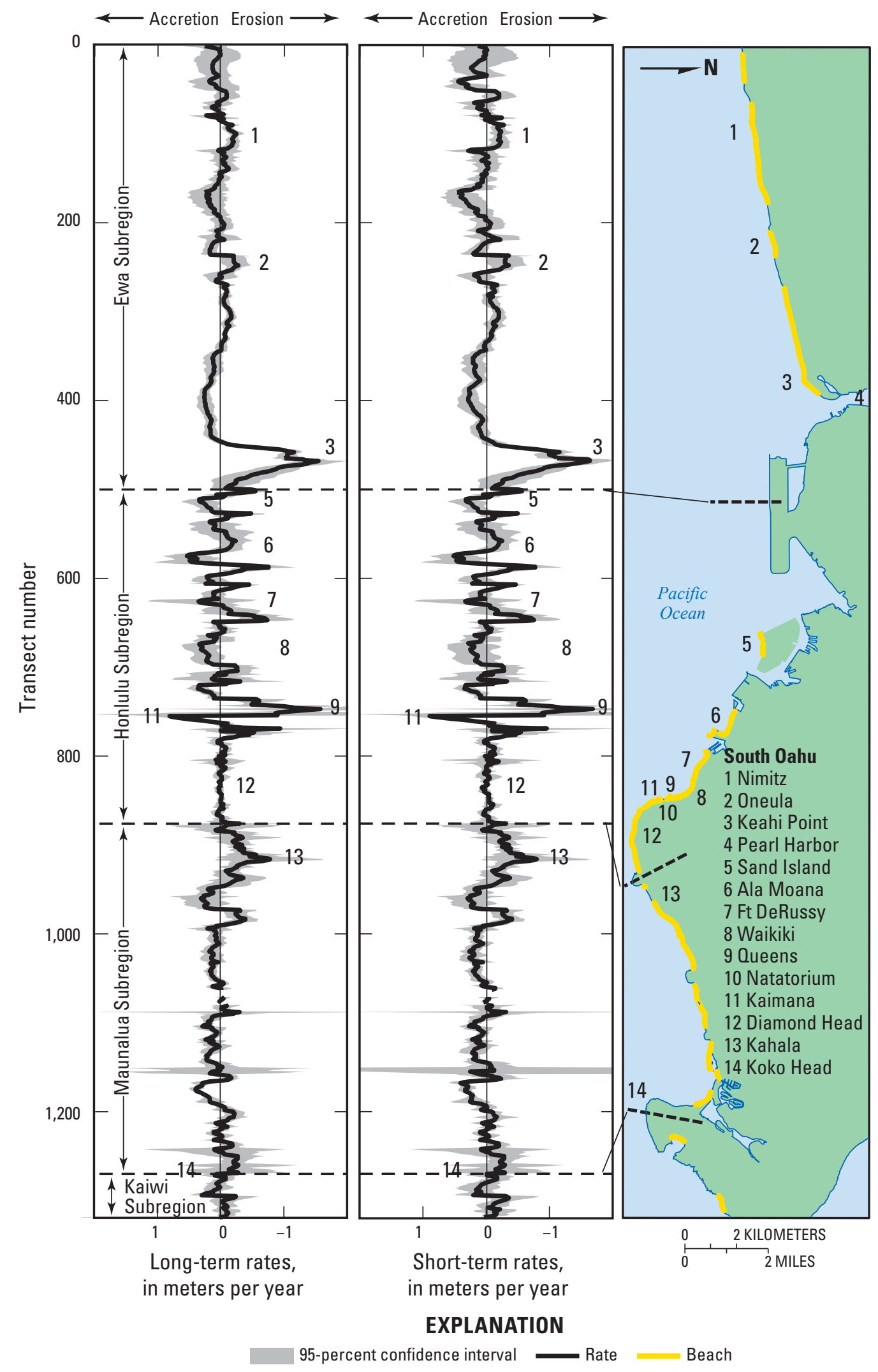

Figure 29. Long-term (all available years) and short-term (1940s to present) shoreline change rates, South Oahu. (Location shown in figure 22) 
The average short-term rate of $-0.03 \pm 0.02 \mathrm{~m} / \mathrm{yr}$ is similar to the average long-term rate. For the long-term rates, as for the short-term rates, the percentages of eroding and accreting transects are approximately equal (table 5). The maximum short-term erosion and accretion rates were measured at the same locations as the maximum long-term erosion and accretion rates, respectively (Kaimana and Queens, Waikiki).

The long-term and short-term rates follow similar trends (fig. 29) along the shore and average rates and percentages of eroding and accreting transects are similar in the long- and short-term shoreline changes. Similarities between long- and short-term trends along South Oahu may be a result of extensive use of truncated data sets for rate calculation in areas with engineered shoreline (only recent shorelines used for longand short-term analysis) and limited availability of pre-WWII shorelines for many areas (for example, only one shoreline removed from the data set for short-term rate calculation).

\section{West Oahu}

Oahu's leeward western coast consists of sandy beach embayments and basaltic and limestone headlands. The shore is exposed to refracted North Pacific swells in winter and southerly swells in summer. Easterly trade winds blow offshore along most of this coastline. Southerly Kona storm winds blow onshore and can cause temporary beach erosion. Shoreline position is highly variable at many beaches in this region, as sand shifts alongshore with alternating wave direction between the North Pacific and southern swell seasons. There is a moderate risk of coastal flooding from large winter waves and when tropical storms pass near this region (Fletcher and others, 2002).

Most of the coast is gently sloping. The coast becomes more rocky and narrow near Kaena Point (northwestern point of Oahu). The shoreline is composed of carbonate sand and limestone rock, and beach rock is prevalent (Fletcher, 2010). The West region is made up of three subregions: Makua, Waianae, and Nanakuli. The three subregions in West Oahu have from 6 to 12 shorelines, with a date range from 1910 to 2007 (table 8). Forty-six and 26 percent of the rates at the 628 transects are significant in the long- and short-term, respectively (fig. 30).

West Oahu is the most erosional region of the island, with an average long-term rate of $-0.25 \pm 0.01 \mathrm{~m} / \mathrm{yr}$ and 83 percent of transects indicating erosion in the long term (table 5). All three subregions are erosional in the long term, with average rates of at least $-0.20 \mathrm{~m} / \mathrm{yr}$ (table 10). The maximum long-term erosion rate $(-1.2 \pm 0.5 \mathrm{~m} / \mathrm{yr})$ was found in the northern part of Maili Beach (table 9, fig. 31) and is at least partly the result of removal of sand by mining operations in the mid-1900s (Hwang, 1981; Sea Engineering, Inc., 1988). Sand mining was widespread along western Oahu beaches and also likely affects shoreline change rates at Makua and Yokohama (Campbell and Moberly, 1978; Hwang, 1981). Other areas with significant erosion rates include Makua (up to $-0.4 \pm 0.3 \mathrm{~m} / \mathrm{yr}$, as a result of sand mining), Keaau (up to $-1.0 \pm 0.3 \mathrm{~m} / \mathrm{yr}$ ), Mauna Lahilahi (up to $-0.3 \pm 0.1 \mathrm{~m} / \mathrm{yr}$ ), Pokai (up to $-0.4 \pm$ $0.3 \mathrm{~m} / \mathrm{yr}$ ), Nanakuli (up to $-0.3 \pm 0.1 \mathrm{~m} / \mathrm{yr}$ ), and Tracks (up to $-0.5 \pm 0.2 \mathrm{~m} / \mathrm{yr})$. The maximum accretion rate $(1.7 \pm 0.6 \mathrm{~m} / \mathrm{yr})$ was found in the southern part of Pokai Bay. This section of beach has been accreting since the construction of a breakwater in the 1950s.

The average short-term rate of $-0.13 \pm 0.02 \mathrm{~m} / \mathrm{yr}$ is less erosive than the average long-term rate (table 5). Seventy-one percent of transects indicate erosion in the short term, compared to 83 percent in the long term. The maximum short-term erosion rate $(-1.0 \pm 0.3 \mathrm{~m} / \mathrm{yr})$ is at the southern end of Yokohama Beach (table 9), where sand mining occurred from 1949 to 1972 (Hwang, 1981). The maximum short-term accretion rate $(1.7 \pm 0.6 \mathrm{~m} / \mathrm{yr})$ was found at Pokai Bay, the same location at which the maximum long-term rate was measured. Rates at this location were calculated with a truncated data set following construction of the breakwater.

The long-term and short-term shoreline change rates follow similar trends (fig. 30). Short-term rates typically have a higher associated uncertainty as a result of a shortened data set. The short-term rates at Yokohama, Keaau, and Maili are less erosive than the long-term rates, indicating that shoreline recession may have slowed since sand-mining operations ceased.

\section{Maui}

Maui is the third largest of the Hawaiian Islands. It is composed of two shield volcanoes, West Maui and Haleakala, with a low-lying isthmus separating them. The approximately $90 \mathrm{~km}$ of sandy beach on Maui is separated into three subregions for analysis: North Maui, Kihei, and West Maui (fig. 32). From 3 to 10 high-quality historical shorelines with dates ranging from 1899 to 2007 are available for Maui (table 11). The shoreline from the earliest time period was derived from a T-sheet; all other shorelines were derived from vertical aerial photographs.

Maui's beaches are the most erosional among the three islands (table 5). Average shoreline change rates for all analysis regions and subregions are erosional (tables 5 and 12). The average long-term rate for all transects is $-0.17 \pm 0.01 \mathrm{~m} / \mathrm{yr}$ and the average short-term rate is $-0.15 \pm 0.01 \mathrm{~m} / \mathrm{yr}$. A majority of the Maui transects indicate erosion with 85 percent of the long-term rates erosional and 76 percent of the short-term rates erosional. Eleven percent $(6.8 \mathrm{~km})$ of the total extent of Maui beaches studied was lost to erosion during the analysis period - the highest percentage of the three islands. 


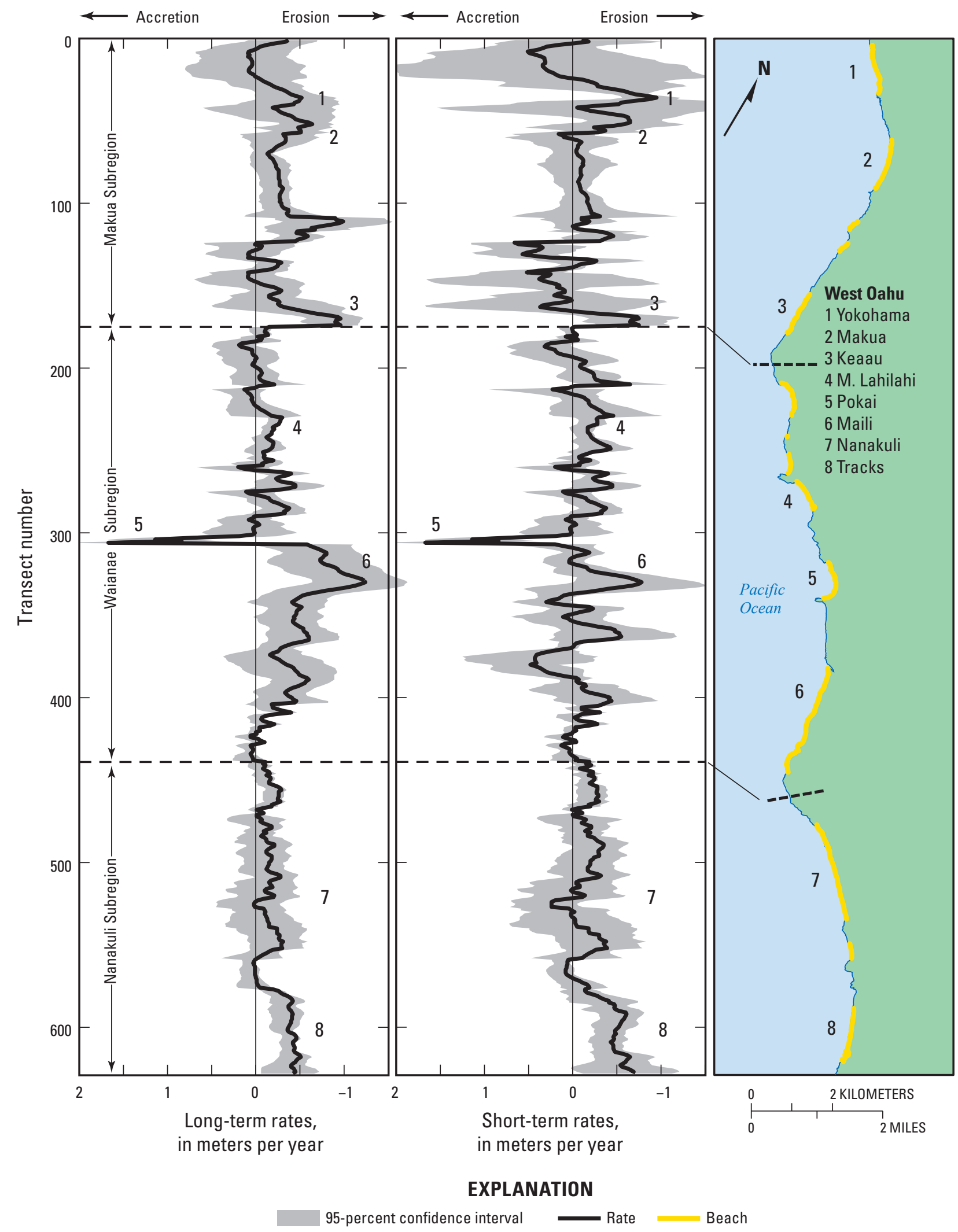

Figure 30. Long-term (all available years) and short-term (1940s to present) shoreline change rates, West Oahu. (Location shown in figure 22) 


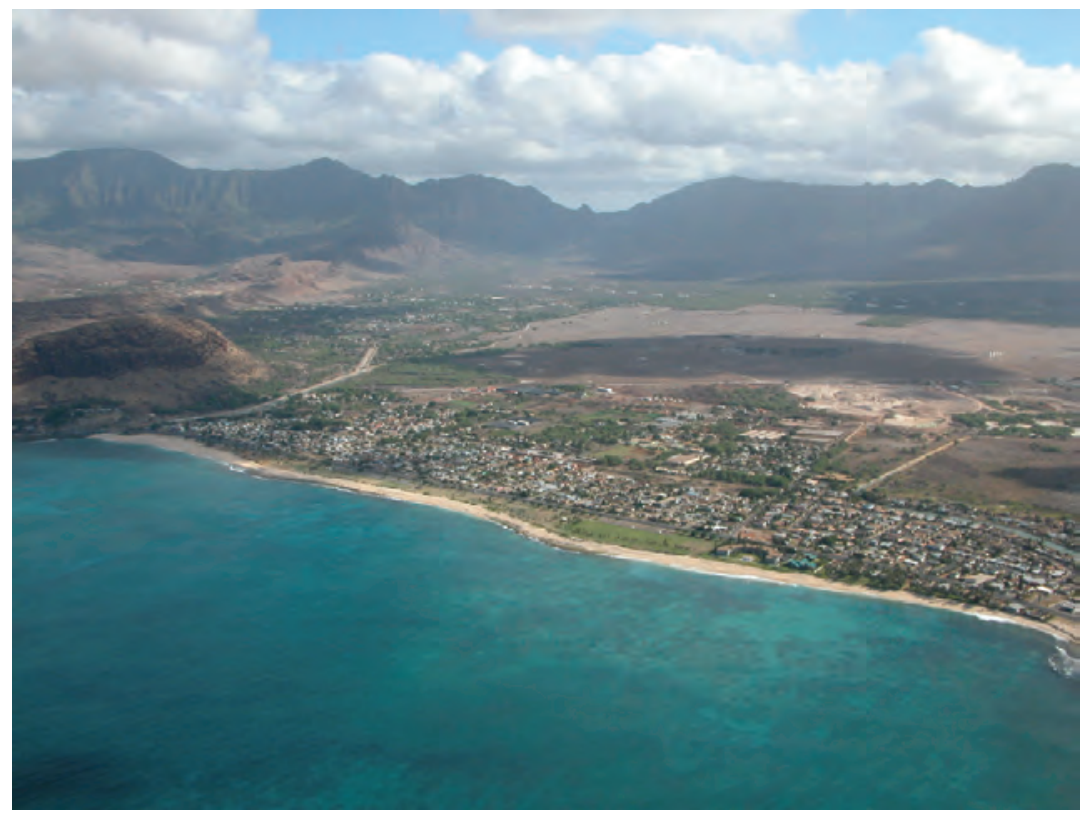

Figure 31. Maili Beach, West Oahu. (Location shown in figure 30) (Photograph by Andrew D. Short, University of Sydney)

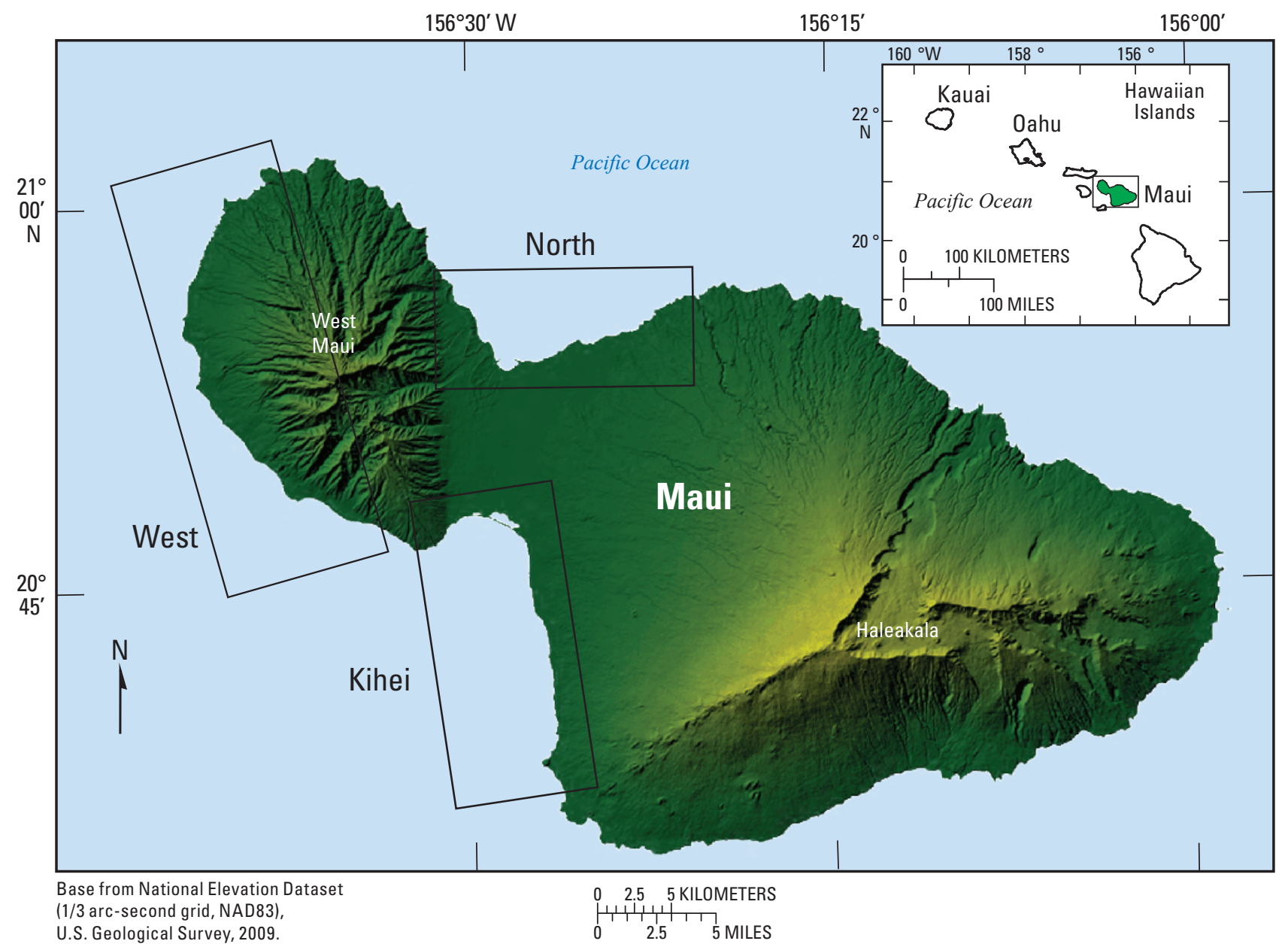

Figure 32. Three regions of Maui: north, Kihei, and west. 
Table 11. Number and range in years of historical shorelines for long- and short-term shoreline change analysis on Maui.

\begin{tabular}{|c|c|c|c|c|}
\hline \multirow{3}{*}{ Region } & \multicolumn{4}{|c|}{ Shoreline change } \\
\hline & \multicolumn{2}{|c|}{ Long-term } & \multicolumn{2}{|c|}{ Short-term } \\
\hline & Number of shorelines ${ }^{1}$ & Range in years ${ }^{1}$ & Number of shorelines ${ }^{1}$ & Range in years ${ }^{1}$ \\
\hline North & $4-8$ & $1899-2002$ & $3-5$ & 1960-2002 \\
\hline Kihei & $3-9$ & 1900-2007 & $3-8$ & 1949-2007 \\
\hline West & $5-10$ & $1912-1997$ & $3-8$ & 1949-1997 \\
\hline
\end{tabular}

${ }^{1}$ Number of shorelines and range in years vary in each region.

Table 12. Average shoreline change rates for Maui subregions. $[\mathrm{m} / \mathrm{yr}$, meters per year; \pm , plus or minus]

\begin{tabular}{clrrr}
\hline \multirow{2}{*}{$\begin{array}{c}\text { Re- } \\
\text { gion }\end{array}$} & Subregion & $\begin{array}{c}\text { Number } \\
\text { of tran- }\end{array}$ & \multicolumn{2}{c}{ Average rate (m/yr) } \\
\cline { 4 - 5 } & & sects & Long-term & Short-term \\
\hline \multirow{2}{*}{ North } & Waihee-Waiehu & 277 & $-0.12 \pm 0.02$ & $-0.17 \pm 0.02$ \\
& Kahului Harbor & 63 & $-0.05 \pm 0.03$ & $-0.06 \pm 0.08$ \\
& Kanaha-Paia & 563 & $-0.35 \pm 0.02$ & $-0.26 \pm 0.04$ \\
\hline \multirow{2}{*}{ Kihei } & Makena-Wailea & 335 & $-0.13 \pm 0.02$ & $-0.13 \pm 0.02$ \\
& Central Kihei & 283 & $-0.07 \pm 0.03$ & $-0.12 \pm 0.03$ \\
& Maalaea Bay & 393 & $-0.17 \pm 0.02$ & $-0.10 \pm 0.04$ \\
\hline \multirow{2}{*}{ West } & Lahaina & 986 & $-0.15 \pm 0.01$ & $-0.11 \pm 0.01$ \\
& Kaanapali & 228 & $-0.08 \pm 0.02$ & $-0.13 \pm 0.03$ \\
& Napili-Kapalua & 305 & $-0.22 \pm 0.02$ & $-0.19 \pm 0.03$ \\
\hline
\end{tabular}

\section{North Maui}

The northern shore of Maui (fig. 33) is a gently embayed coastal system exposed to wind and waves from the northeast, north, and northwest. The shore experiences large swell during winter months and short-period trade wind waves throughout the year. The area also has a history of tsunami inundation. The North Maui region was divided into three subregions for additional analysis. The eastern Waihee-Waiehu subregion is affected by heavy rainfall and runoff from the dissected watersheds of the West Maui highlands and is dominated by cobble and sand beaches. The central study beaches, from Kahului Harbor to Baldwin Park (Kahului and Kanaha-Paia subregions) have low-lying hinterlands and a sand-rich coastal plain. A fringing reef is found along both the central and eastern study areas. The eastern study beaches, beginning at Paia, have a narrow, rocky coastal plain at the base of Haleakala volcano. This subregion contains short, embayed pocket beaches and narrow perched beaches located on lowelevation rocky terraces (fig. 34).
Along North Maui, the number of historical shorelines ranges from four to eight, with dates ranging from 1899 to 2002 (table 11). Of the 903 transects, 38 percent of the longterm rates and 27 percent of the short-term rates are statistically significant (fig. 33). Despite seasonal variability in shoreline position caused by large winter waves, the percentage of rates that are significant is higher for North Maui than for the other two Maui regions - resulting in an overall trend of chronic erosion.

The average long-term rate for all North Maui beaches, $-0.26 \pm 0.02 \mathrm{~m} / \mathrm{yr}$, is the most erosional average rate of any region on the three islands (table 5; approximately the same as West Oahu: $-0.25 \pm 0.01 \mathrm{~m} / \mathrm{yr}$ ). Average long-term rates for each of the North Shore subregions are erosional (table 12). Eighty-seven percent of the transects along North Maui indicate a trend of erosion in the long term and 74 percent indicate a trend of erosion in the short term. The maximum erosion rate $(-1.5 \pm 1.1 \mathrm{~m} / \mathrm{yr})$ was found in front of an offshore rock bench at Baldwin Park (table 13). Shoreline recession at Baldwin is, in part, the result of sand-mining operations for a now-defunct lime kiln. A bench of beach rock was previously linked to the beach by a tombolo, but is now isolated offshore (Genz and others, 2009). Other areas of significant erosion were found at Waiehu Beach Park (up to $-0.5 \pm 0.3 \mathrm{~m} / \mathrm{yr}$, long term) and Kanaha Beach Park (up to $-1.5 \pm 0.7 \mathrm{~m} / \mathrm{yr}$, long term). The maximum long-term accretion rate $(1.5 \pm 1.3 \mathrm{~m} / \mathrm{yr})$ was measured between two groins at Kanaha Beach Park.

The average short-term shoreline change rate for North Shore beaches, $-0.22 \pm 0.03 \mathrm{~m} / \mathrm{yr}$, is roughly the same as the average long-term rate (table 5). Seventy-four percent of the beach is erosional in the short term. The maximum short-term erosion rate $(-2.2 \pm 1.1 \mathrm{~m} / \mathrm{yr})$ was found in the same location as the maximum long-term erosion rate-Baldwin Park (table 13). The maximum short-term accretion rate $(2.1 \pm$ $0.2 \mathrm{~m} / \mathrm{yr}$ ), like the maximum long-term accretion rate, was found in Kanaha Beach Park. Short-term and long-term rates follow a similar pattern, though uncertainty is higher in the short-term rate because of the truncated data set. 


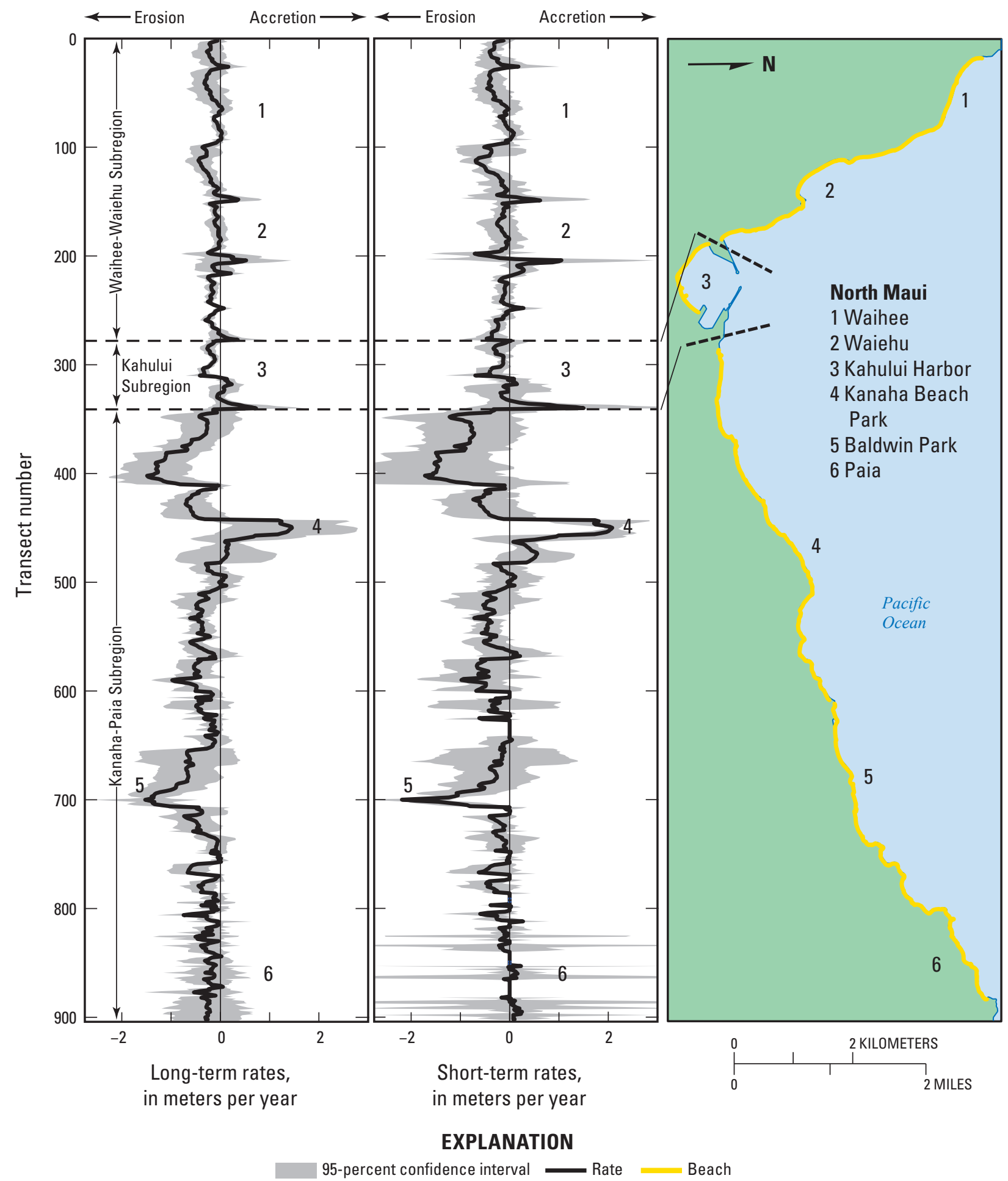

Figure 33. Long-term (all available years) and short-term (1940s to present) shoreline change rates, North Maui. (Location shown in figure 32) 


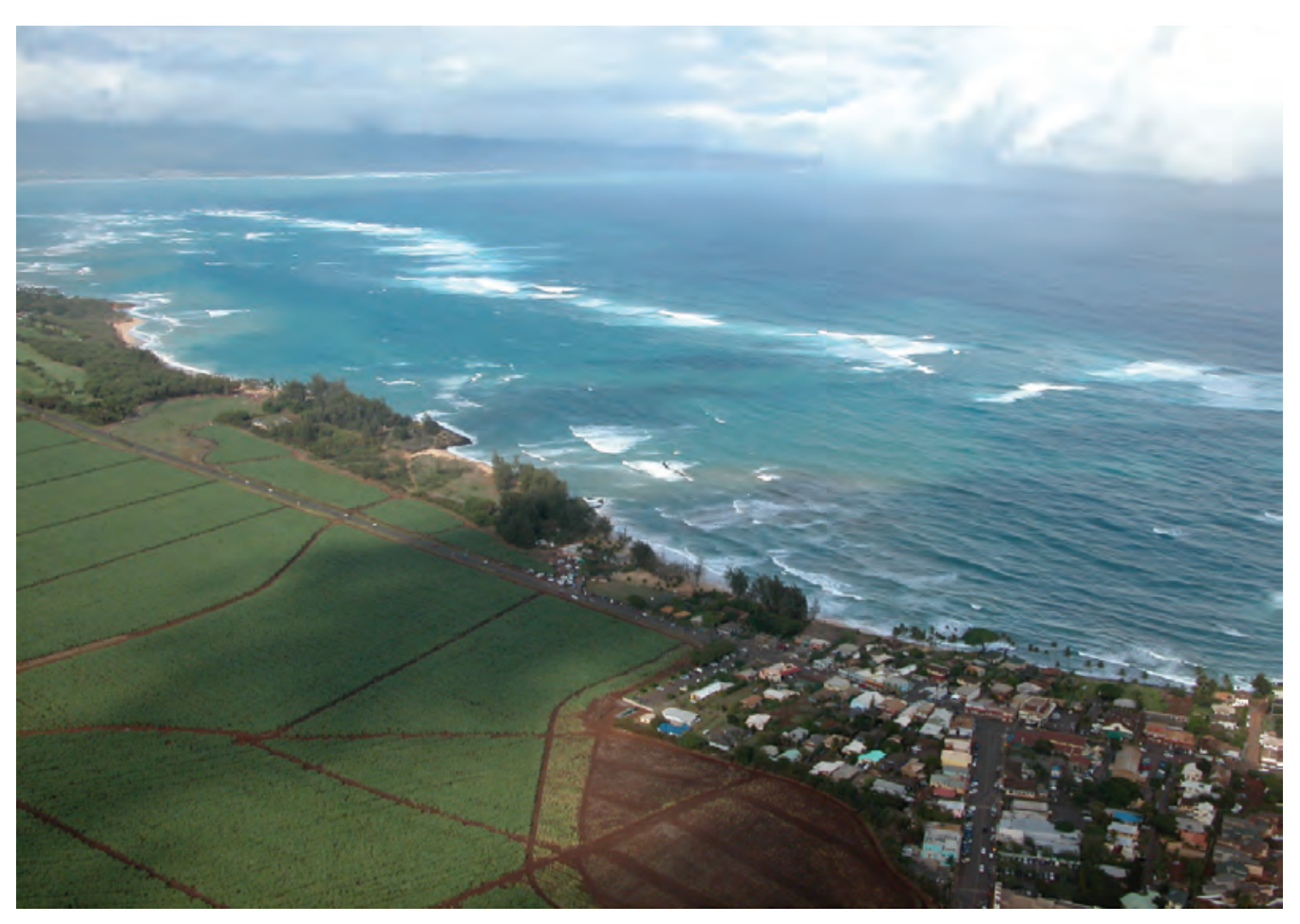

Figure 34. North Maui beaches, looking west from Paia toward Baldwin Park. (Location shown in figure 33) (Photograph by Andrew D. Short, University of Sydney)

Table 13. Maximum shoreline change rates on Maui.

[m/yr, meters per year; max., maximum; \pm , plus or minus]

\begin{tabular}{|c|c|c|c|c|}
\hline Region & $\begin{array}{c}\text { Long-term rate } \\
(\mathrm{m} / \mathrm{yr})\end{array}$ & Location' ${ }^{1}$ & $\begin{array}{c}\text { Short-term rate } \\
(\mathrm{m} / \mathrm{yr})\end{array}$ & Location ${ }^{1}$ \\
\hline \multicolumn{5}{|c|}{ North } \\
\hline Max. accretion & $1.5 \pm 1.3$ & Kanaha Beach Park, groins & $2.1 \pm 0.2$ & Kanaha, groins ${ }^{2}$ \\
\hline \multicolumn{5}{|c|}{ Kihei } \\
\hline Max. erosion & $-1.1 \pm 0.6$ & Kawililipoa, within fishpond remains & $-1.8 \pm 7.5$ & Kalepolepo Beach Park, beach lost \\
\hline \multicolumn{5}{|c|}{ West } \\
\hline Max. erosion & $-0.9 \pm 0.6$ & Ukumehame, coastal road revetment & $-0.7 \pm 1.7$ & Kapalua, Mokuleia Beach, variable \\
\hline Max. accretion & $0.6 \pm 0.2$ & Lahaina, Puunoa Point & $0.7 \pm 0.2$ & Lahaina, Puunoa Point \\
\hline
\end{tabular}

${ }^{1}$ Locations shown in figures 33,35 , and 38.

${ }^{2}$ Maximum erosion or accretion for Maui.

${ }^{3}$ Maximum erosion or accretion for all three islands (Kauai, Oahu, and Maui).

\section{Kihei Maui}

The Kihei coast (fig. 35) is a deeply-embayed shoreline in the north (Maalaea Bay) and partially embayed series of pocket beaches in the south along the southwest flank of Haleakala Volcano. The coast is mostly shadowed from large ocean swell by the islands of Molokai, Lanai, and Kahoolawe. Refracted winter North Pacific swells affect the southern portion of the coast. Southern swell can affect the entire coastline in summer months causing substantial seasonal shifts in shoreline position. Kona storms also cause short-term erosion along this south- to west-facing coast.
The Kihei coast is divided into three subregions for further analysis: Makena-Wailea, Central Kihei, and Maalaea Bay (fig. 35). The coastal plain in the north, along Maalaea Bay, is a flat, sand-rich terrace with barrier beaches, dunes, and wetlands that have been greatly affected by development (fig. 36). The coastal plain becomes progressively narrower to the south with basalt headlands marking boundaries between watersheds lacking dissected valleys. The fringing reef along the Kihei coast is generally narrower and deeper than along North and West Maui. The beaches in the northern and southern sections of Kihei are generally wider than those in the central portion (fig. 37). 


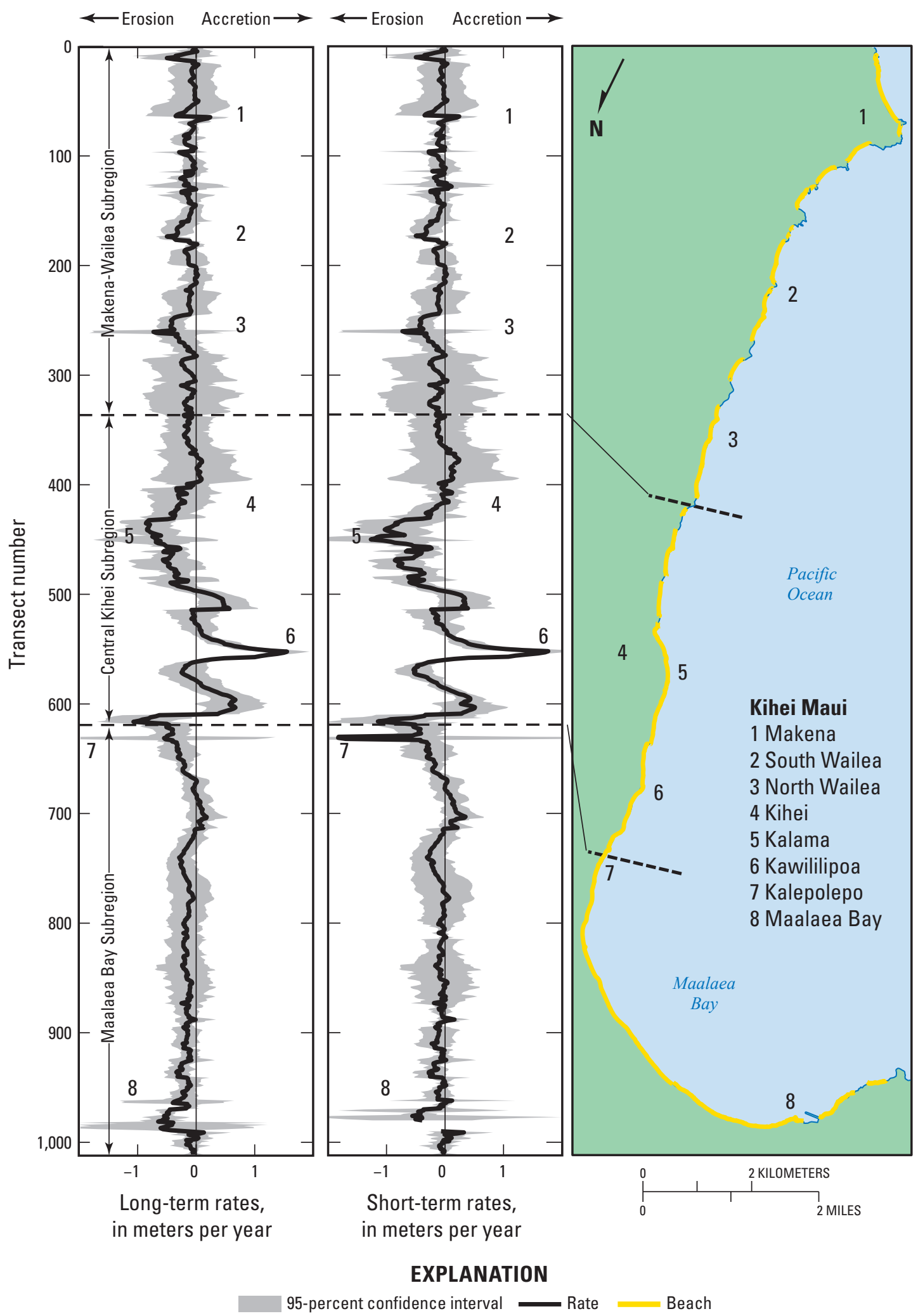

Figure 35. Long-term (all available years) and short-term (1940s to present) shoreline change rates, Kihei, Maui. (Location shown in figure 32) 


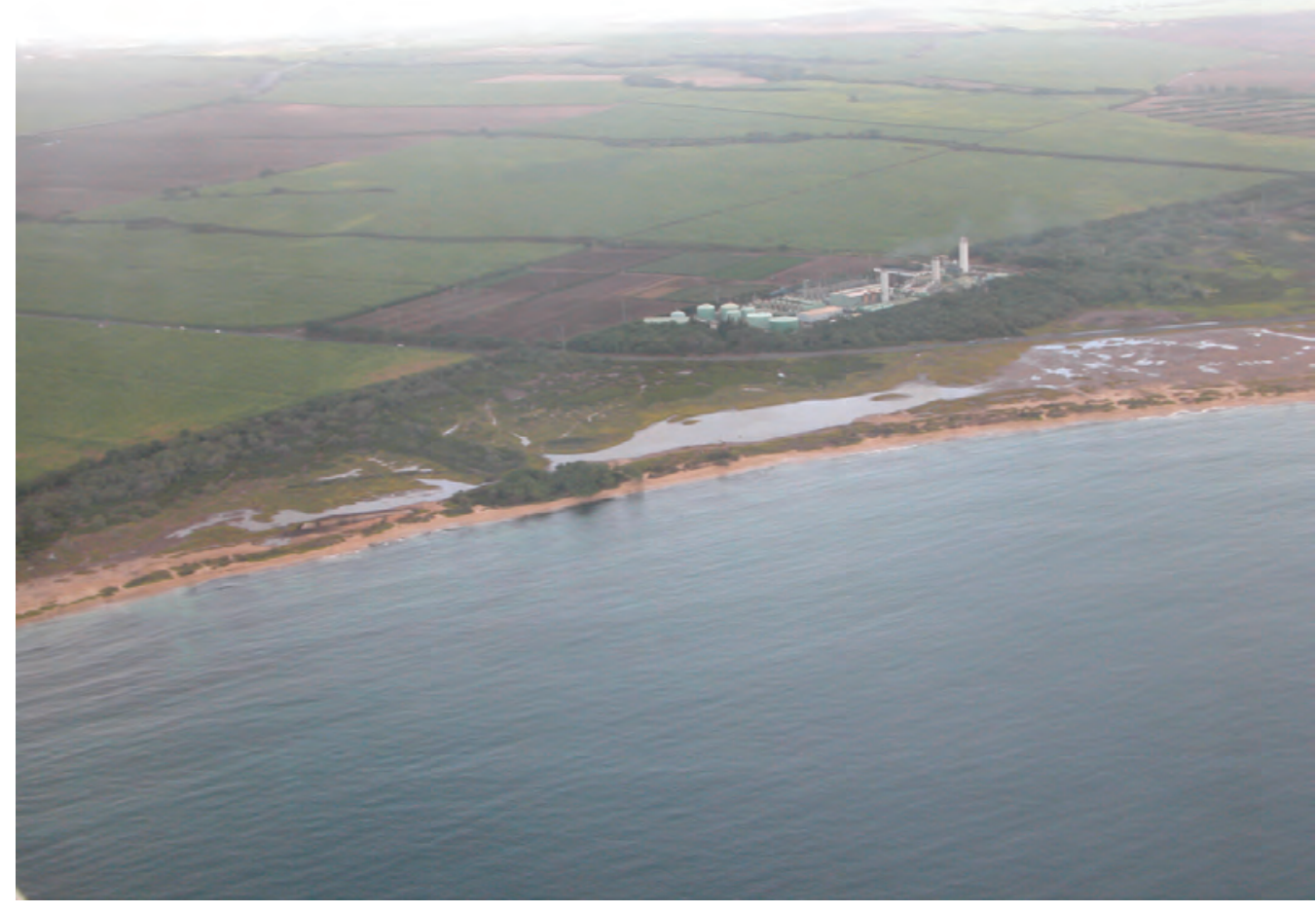

Figure 36. Maalaea Bay Beach with dunes and wetlands, north Kihei coast, Maui. (Location shown in figure 35) (Photograph by Andrew D. Short, University of Sydney)

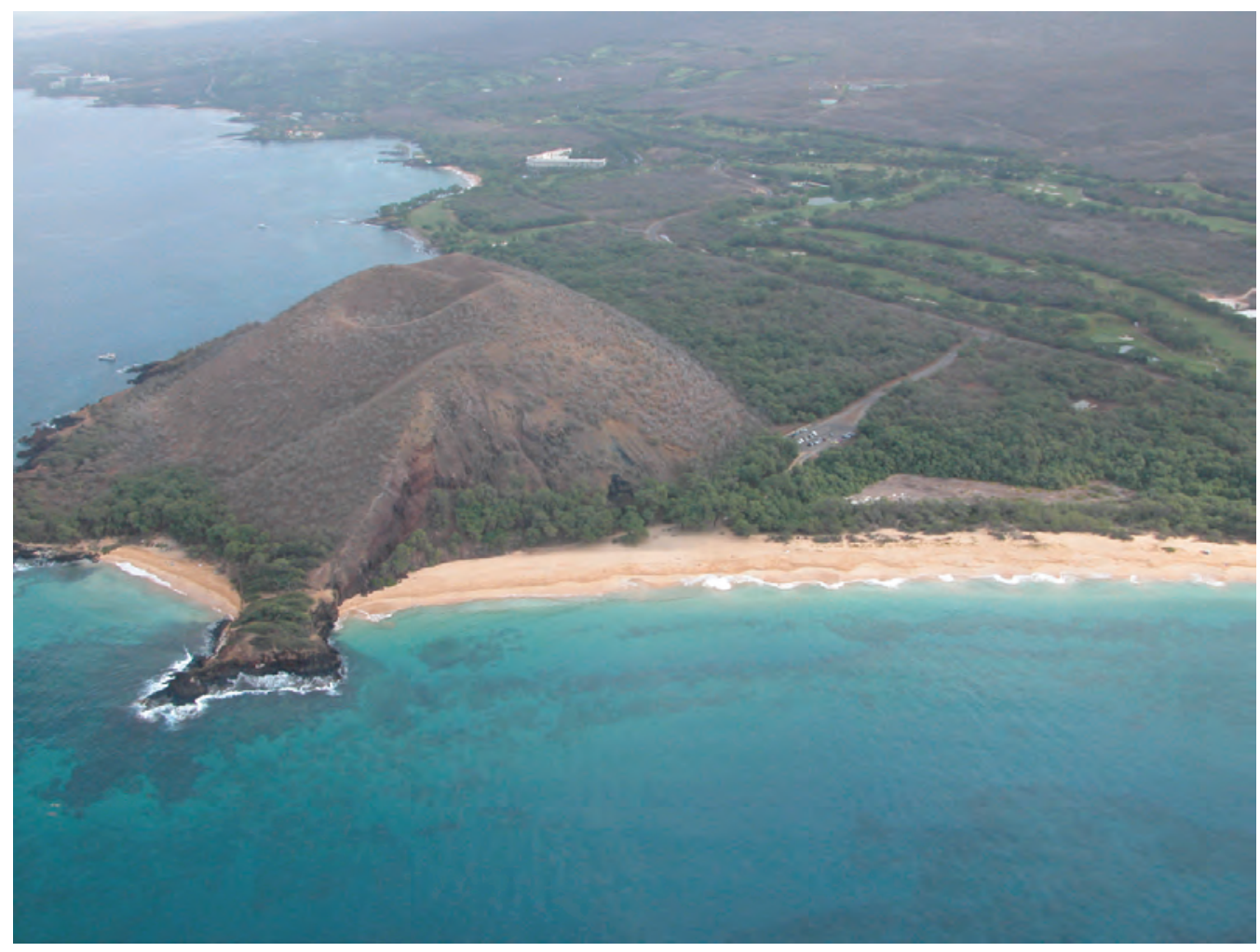

Figure 37. Makena Beach, southern Kihei coast, Maui. (Location shown in figure 35) (Photograph by Andrew D. Short, University of Sydney) 
Kihei is highly erosional compared to study regions of Kauai and Oahu, based on average rates and percentages of transects indicating erosion (table 5). However, rates along Kihei are lower than along the highly erosional beaches of North Maui. Of the 1,011 transects in Kihei, statistically significant change rates were found at 22 percent of transects in the long term and 19 percent of transects in the short termthe lowest percentages in the three Maui regions (fig. 35). The low proportion of significant rates at Kihei relative to the other Maui regions may be a result of high short-term variability in shoreline position (noise), as the number and range of dates of historical shorelines available ( 3 to 9 shorelines, 1900 to 2007) are similar to those in other Maui regions (table 11). Two km, or 11 percent, of the total length of Kihei beaches analyzed in this study was completely lost to erosion. The average longterm rate of shoreline change at Kihei is $-0.13 \pm 0.01 \mathrm{~m} / \mathrm{yr}$. Eighty-three percent of transects are erosional in the long term and 77 percent are erosional in the short term. The maximum long-term erosion rate $(-1.1 \pm 0.6 \mathrm{~m} / \mathrm{yr})$ was found at Kawililipoa, in the remains of a fish pond (table 13). Other areas with substantial long-term erosion include South Wailea (up to $-0.5 \pm 0.2 \mathrm{~m} / \mathrm{yr}$ ), North Wailea (up to $-0.4 \pm 0.2 \mathrm{~m} / \mathrm{yr}$ ), Kalama Park (up to $-0.8 \pm 0.5 \mathrm{~m} / \mathrm{yr}$; beach lost), and Maalaea (up to $-0.6 \pm 0.2 \mathrm{~m} / \mathrm{yr}$ ). The maximum long-term accretion rate $(1.6 \pm 0.4 \mathrm{~m} / \mathrm{yr})$ was also found at Kawililipoa, along an accretional cusp.

The average short-term rate is $-0.12 \pm 0.02 \mathrm{~m} / \mathrm{yr}$, and 77 percent of the short-term rates are erosional (table 5). The maximum short-term erosion rate $(-1.8 \pm 7.5 \mathrm{~m} / \mathrm{yr})$ was found at Kalepolepo Beach Park, where the beach has been completely lost to erosion. The maximum short-term accretion rate was found at the same location as the maximum long-term accretion rate (Kawililipoa; $1.8 \pm 0.8 \mathrm{~m} / \mathrm{yr}$ ). Long- and shortterm rates have similar overall trends.

\section{West Maui}

West Maui (fig. 38) has a gently arcing convex coast. From south to north, the shoreline changes orientation from southwest-, to west-, to northwest-facing. The shoreline is generally characterized by lengths of sandy beach interrupted by rocky headlands and engineered structures (fig. 39). The islands of Molokai, Lanai, and Kahoolawe offer partial protection from swells. The region is affected by alternating summer southern swell and the winter North Pacific swell that causes substantial changes in the beach profile and shifts in sediment along the coast. This region is heavily dissected by watersheds that produce large alluvial fans during low sealevel stands. Shallow fringing reefs line much of this coast, especially in the central and southern portions. Most beaches are narrow and often sand depleted. West Maui is divided into three subregions for further analysis: Lahaina, Kaanapali, and Napili-Kapalua.

West Maui has from 5 to 10 historical shorelines, with dates ranging from 1912 to 1997 (table 11). Of the 1,519 transects, 27 percent of long-term rates and 18 percent of shortterm rates are significant (fig. 38). Roughly 4 km, or 14 percent, of the total length of beach analyzed was completely lost to erosion during the study period - the highest percentage of beach loss of any region on the three islands (tied with South Kauai, table 5).

The average of all long-term rates for West Maui is $-0.15 \pm 0.01 \mathrm{~m} / \mathrm{yr}$ and 85 percent of transects are erosional in the long term. All subregions in West Maui are erosional in the long and short term based on average rates. The NapiliKapalua subregion has the highest average erosion rates, $-0.22 \pm 0.02 \mathrm{~m} / \mathrm{yr}$ in the long term and $-0.19 \pm 0.03 \mathrm{~m} / \mathrm{yr}$ in the short term (table 12). The maximum erosion rate $(-0.9 \pm$ $0.6 \mathrm{~m} / \mathrm{yr}$ ) was found at Ukumehame adjacent to a boulder revetment installed to protect the coastal highway (table 13). Other areas of significant long-term erosion include Hekili Point (up to $-0.3 \pm 0.2 \mathrm{~m} / \mathrm{yr}$ ), Olowalu (up to $-0.3 \pm 0.2 \mathrm{~m} / \mathrm{yr}$ ), Launiupoko (up to $-0.5 \pm 0.3 \mathrm{~m} / \mathrm{yr}$ ), Puamana (up to $-0.5 \pm$ $0.2 \mathrm{~m} / \mathrm{yr}$ ), Mala Wharf (up to $-0.5 \pm 0.4 \mathrm{~m} / \mathrm{yr}$ ), Honokowai (up to $-0.5 \pm 0.4 \mathrm{~m} / \mathrm{yr}$ ), Kahana (up to $-0.4 \pm 0.1 \mathrm{~m} / \mathrm{yr}$ ), and Napili Bay (up to $-0.4 \pm 0.2 \mathrm{~m} / \mathrm{yr}$ ) The maximum long-term accretion rate $(0.6 \pm 0.2 \mathrm{~m} / \mathrm{yr})$ was measured at Puunoa Point. The accretional cell at Puunoa Point is flanked by erosion at the Lahaina and Mala Wharf shorefronts, suggesting that eroded sediment is transported from the adjacent beaches and deposited at Puunoa Point.

Erosion at West Maui is slightly lower in the short-term than in the long-term rate, with an average short-term rate of $-0.13 \pm 0.01 \mathrm{~m} / \mathrm{yr}$, and 77 percent of transects are erosional (table 5). The maximum short-term erosion rate $(-0.7 \pm$ $1.7 \mathrm{~m} / \mathrm{yr}$ ) was found at Mokuleia Beach (table 13). The percentage of accretion increased from 14 (for long-term rates) to 18 (for short-term rates). The maximum short-term accretion rate was found at the same location as the maximum rate in the long-term analysis (Puunoa Point at Lahaina). 


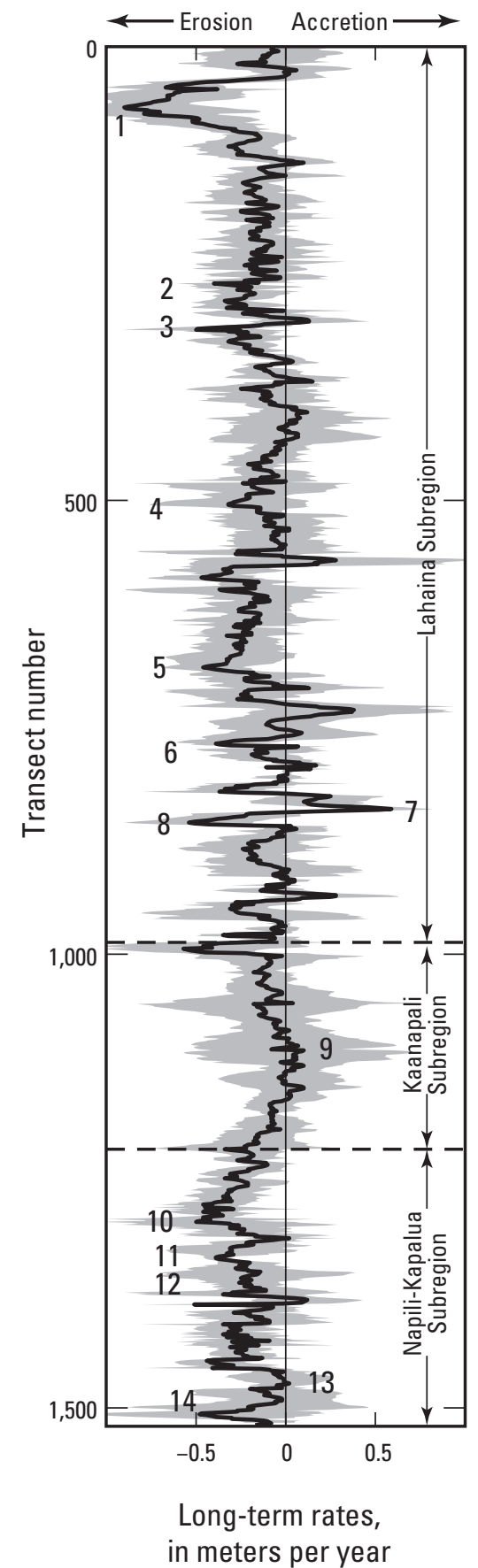

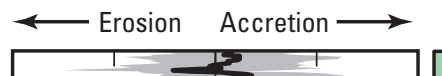
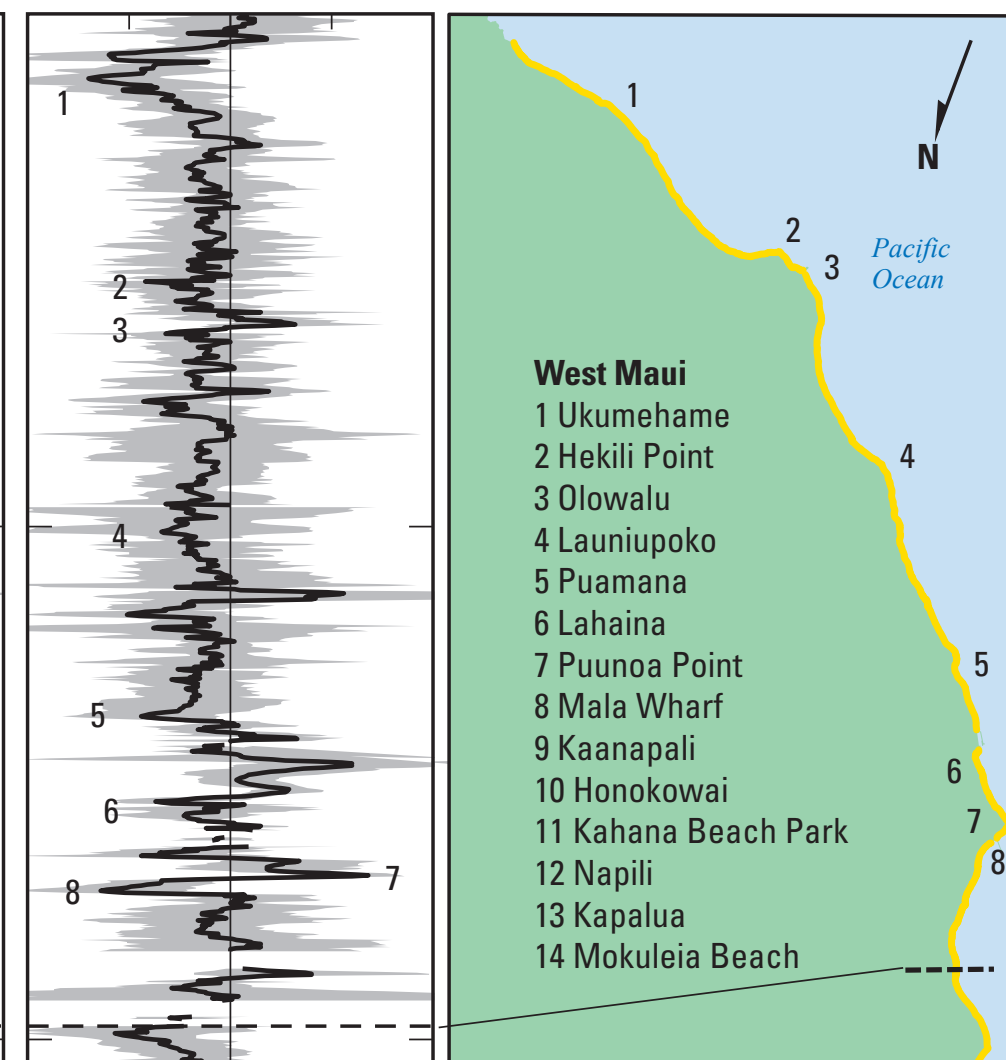

West Maui

1 Ukumehame

2 Hekili Point

3 Olowalu

4 Launiupoko

5 Puamana

6 Lahaina

7 Puunoa Point

8 Mala Wharf

9 Kaanapali

10 Honokowai

11 Kahana Beach Park

12 Napili

13 Kapalua

14 Mokuleia Beach

4

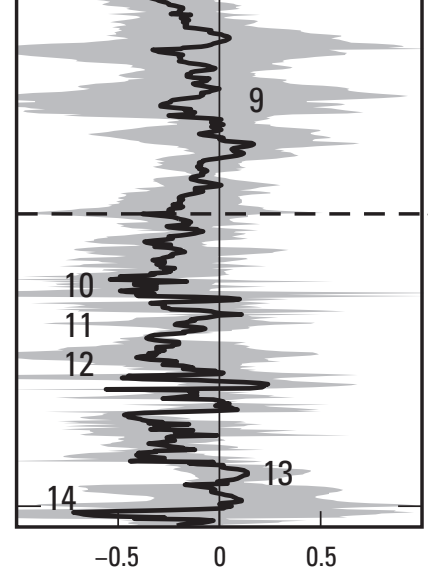

9

Short-term rates, in meters per year

\section{EXPLANATION}

Figure 38. Long-term (all available years) and short-term (1940s to preset) shoreline change rates, West Maui. (Location shown in figure 32) 


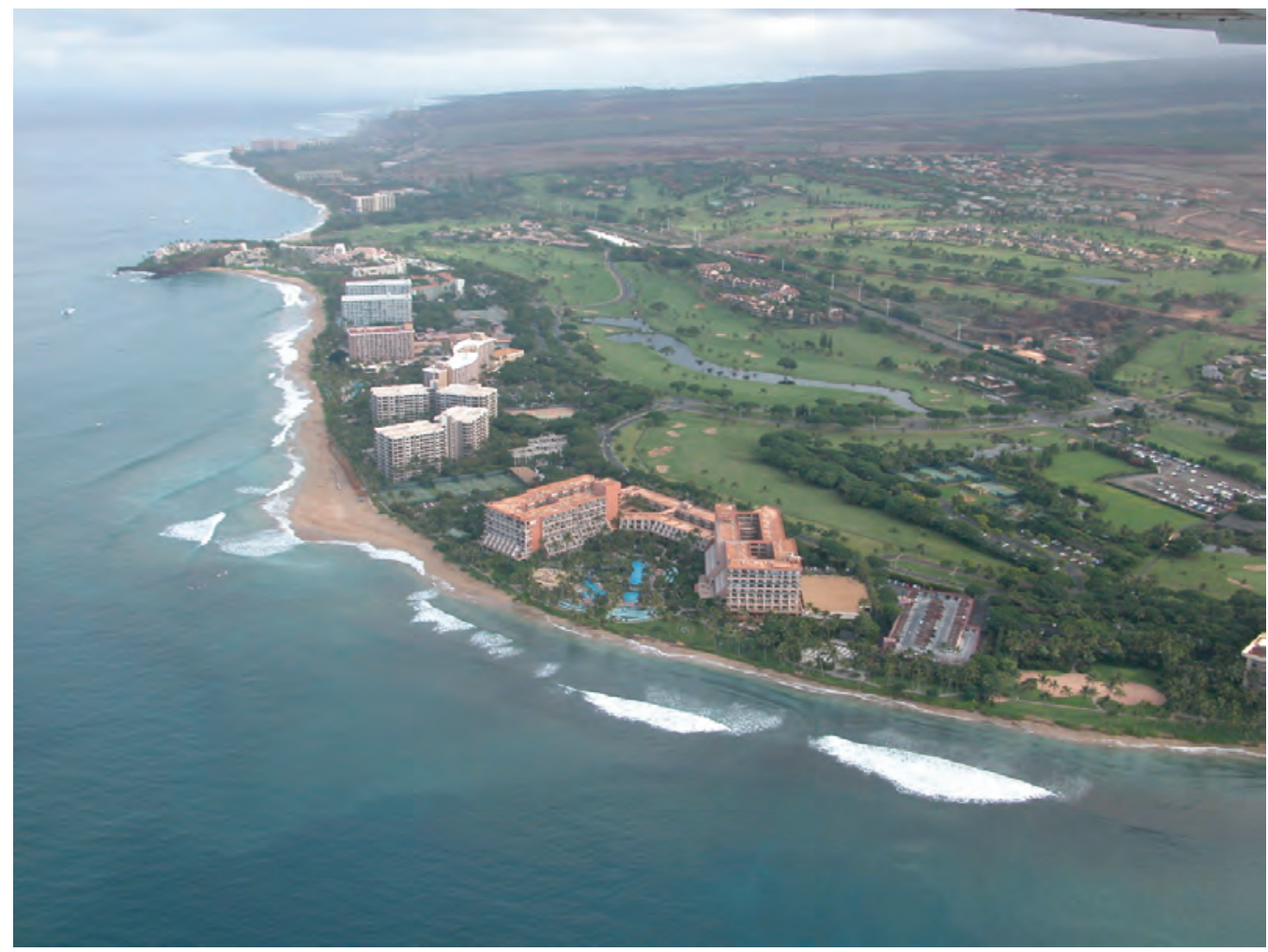

Figure 39. Kaanapali Beach, West Maui. (Location shown in figure 38) (Photograph by Andrew D. Short, University of Sydney)

\section{Discussion and Additional Considerations}

\section{Summary of Shoreline Changes}

Shoreline change along Kauai, Oahu, and Maui beaches is dominated by erosion. However, shoreline change is highly variable along Hawaii beaches with cells of erosion and accretion typically separated by only a few hundred meters on continuous beaches or by short headlands that divide the coast into many small embayments. Twenty-two km or 9 percent of the total length of beach analyzed was completely lost to erosion during the analysis period (table 5). Oahu lost the greatest total length of beach to erosion $(8.7 \mathrm{~km})$, whereas Maui had the highest percentage of beach loss (11 percent). The average of long-term rates from all transects on the three islands is $-0.11 \pm 0.01 \mathrm{~m} / \mathrm{yr}$ and the majority, or 70 percent, of the transects indicate a trend of erosion in the long term. Erosion is also the short-term trend for the three islands, with an average rate of $-0.06 \pm 0.01 \mathrm{~m} / \mathrm{yr}$ and 63 percent of transects indicating beach erosion. The maximum long-term erosion rate (-1.8 \pm $0.3 \mathrm{~m} / \mathrm{yr}$ ) was measured at Kualoa Point, Oahu. The maximum short-term erosion rate $(-2.2 \pm 1.1 \mathrm{~m} / \mathrm{yr})$ was measured at
Baldwin Park, Maui. The maximum long-term accretion rate $(1.7 \pm 0.6 \mathrm{~m} / \mathrm{yr})$ was measured at Pokai Bay, Oahu. The maximum short-term accretion rate $(2.8 \pm 6.2 \mathrm{~m} / \mathrm{yr})$ was measured at the northern end of Polihale Beach, Kauai, although this rate is associated with a high degree of uncertainty caused by seasonal variability.

Maui beaches are clearly the most erosional of the three islands with average long- and short-term erosion rates of $-0.17 \pm 0.01$ and $-0.15 \pm 0.01 \mathrm{~m} / \mathrm{yr}$, respectively. Eighty-five percent of Maui transects indicate a trend of erosion in the long term and 76 percent indicate erosion in the short-term rates. Long-term trends for Kauai beaches are intermediate with an average rate $-0.11 \pm 0.01 \mathrm{~m} / \mathrm{yr}$ and 71 percent of transects indicating a trend of erosion. Kauai is the only island whose average short-term change rate is not erosional ( $0.02 \pm$ $0.02 \mathrm{~m} / \mathrm{yr}$ ) due largely to increased beach accretion along West Kauai in the short term. Though, the majority (57 percent) of transects on Kauai beaches indicate a trend of erosion. Oahu has the lowest average long-term erosion rate of the three islands at $-0.06 \pm 0.01 \mathrm{~m} / \mathrm{yr}$. However, erosion is still the dominant trend of shoreline change on Oahu with 60 percent of transects indicating a trend of erosion in the long term. Short-term analysis for Oahu signifies a similar trend of erosion as the long-term analysis with an average rate of $-0.05 \pm$ $0.01 \mathrm{~m} / \mathrm{yr}$ and 58 percent of transects indicating erosion. 


\section{Influences of Human Activities}

Coastal property in many areas of Hawaii is at a premium, and the encroachment of the Pacific Ocean onto multimillion-dollar residential and commercial lands and development has not gone unnoticed by landowners. In many cases, the response is to armor the shoreline with seawalls, revetments, sand bags, and other structures and devices. Artificial hardening of the shoreline protects coastal land at the expense of the beach where chronic erosion occurs as waves are prevented from accessing the sand reservoirs impounded behind hard structures. Sandy shoreline adjacent to armoring experiences flanking erosion, extending the erosion problem along the shoreline and subjecting adjacent properties to the challenges of managing erosion. Therefore, efforts to mitigate coastal erosion have created a serious problem of beach loss and flanking erosion resulting from sand deficiency and wave reflection from hard structures along many shorelines in the state, particularly on the most populated and developed islands. The State of Hawaii and local communities acknowledge the need to address this issue, and hope that a broadly scoped management plan will balance the natural morphology of the coast with human-resource needs (Hwang, 2005).

Rates of shoreline change can be influenced by shorestabilization practices. Artificial beach replenishment and engineering structures tend to alter coastal processes, sediment availability, and shoreline position. For example, beach nourishment artificially causes rapid, temporary shoreline accretion. Depending on the frequency of beach nourishment, the placement of large volumes of sand on the beach may bias the rates of observed shoreline change toward accretion or stability, even though the natural beach, in the absence of nourishment, would be eroding.

In Hawaii, nourishment has not played a major role in the management of beach resources around the state other than at Waikiki. The most common stabilization approach has been shoreline hardening in the form of seawalls. Nourishment has largely been restricted to locations where erosion poses an immediate threat to development. Sites of beach nourishment include Sugar Cove on Maui, Waikiki, and Lanikai on Oahu, as well as other isolated locations.

On the island of Oahu, Fletcher and others (1997) found that about 25 percent of sandy beach has narrowed or been completely lost since 1949 as a result of artificial hardening of the shoreline. Differentiating between natural rates of erosion and the influences of beach nourishment is difficult because no experiments have been conducted to address this issue.

Sand mining is another factor that has influenced shoreline positions in Hawaii. Although the practice is not well documented, residents report that sand has been removed from several beaches for use in construction materials or as lime fertilizer used in agriculture. Sand mining operations are observed in a few historical aerial photographs from the 1940s to 1960s. Sand mining may cause a deficiency in the sediment budget that can lead to temporary or chronic erosion.

\section{Planned Updates and Related Research}

The USGS plans to revise and update rates of shoreline change every 5 to 10 years. Therefore, this report and associated data are a work in progress. The revision interval will depend on the availability of new shoreline data and technological advances. Continued monitoring of shoreline change is vital in the coming decades as the dynamics of the coastal environment that lead to beach erosion (for example, sea-level rise, storms, and waves) are likely to change with changing climate.

\section{Acknowledgments}

The authors thank Michael Rink and David Doyle of the National Oceanic and Atmospheric Administration. The authors also thank Jennifer Wozencraft and Thomas Smith of the U.S. Army Corps of Engineers and U.S. Geological Survey (USGS) personnel Ann Gibbs, Thomas Reiss, and Cheryl Hapke. The authors acknowledge Matthew Niles, Daren Suzuki, and Thorne Abbott of the Maui Planning Department for their support of erosion studies on Maui and Sam Lemmo of the Hawaii Department of Land and Natural Resources. The University of Hawaii Sea Grant extension faculty members have been a valuable asset in coastal studies and policy development. The authors also appreciate Kauai County Planning Department, City and County of Honolulu Department of Planning and Permitting, Hawaii Coastal Zone Management, the Hawaii Department of Land and Natural Resources, and the Harold K.L. Castle Foundation for funding erosion studies on Kauai and Oahu.

\section{References Cited}

Allan, J.C., and Komar, P.D., 2000, Are ocean wave heights increasing in the eastern North Pacific?: EOS, Transactions of the American Geophysical Union, v. 47, p. 561-567.

Anderson, T.R., Frazer, L.N., and Fletcher, C., 2010, Transient and persistent shoreline change from a storm: Geophysical Research Letters, v. 37, no. L08401, 5 p.

Armstrong, R.W., ed, 1983, Atlas of Hawaii: Honolulu, Hawaii, University of Hawaii Press, 238 p.

Athens, J.S., and Ward, J.V., 1991, Paleoenvironmental and archaeological investigations, Kawainui Marsh flood control project, Oahu Island, Hawaii: Honolulu, Hawaii, International Archaeological Research Institute, Inc., prepared for U.S. Army Corps of Engineers, Pacific Ocean Division, Fort Shafter, Hawaii, 50 p. 
Aucan, Jerome, 2006, Directional wave climatology for the Hawaiian Islands from buoy data and the influence of ENSO on extreme wave events from wave model hindcast: 9th International Workshop on Wave Hindcasting and Forecasting, JCOMM Technical Report 34/WMO-TD. 1368. Victoria, British Columbia, Canada, September 24-29, 2006, p. 1-20.

Bochicchio, Christopher, Fletcher, C., Dyer, Matthew, and Smith, Thomas, 2009, Reef-top sediment bodies: Windward Oahu, Hawaii: Pacific Science, v. 63, no. 1, p. 61-82.

Caldwell, P.C., 1992, Surfing the El Niño: Mariners Weather $\log 36$, no. 3, p. 60-64.

Caldwell, P.C., 2005, Validity of north shore, Oahu, Hawaiian Islands surf observations: Journal of Coastal Research, v. 21 , no. 6 , p. $1127-1138$.

Caldwell, P.C., Vitousek, S., and Aucan, J.P., 2009, Frequency and duration of coinciding high surf and tides along the north shore of Oahu, Hawaii, 1981-2007: Journal of Coastal Research, v. 25, no. 3, p. 734-743.

Calhoun, R.S., and Fletcher, C., 1996, Late Holocene coastal plain stratigraphy and sea-level history at Hanalei, Kauai, Hawaiian Islands: Quaternary Research, v. 45, no. 1, p. $47-58$.

Casciano, F.M., and Palmer, R.Q., 1969, Potential of offshore sand as an exploitable resource in Hawaii: Honolulu, Hawaii, University of Hawaii Sea Grant Program, Grant no. $69-4,32 \mathrm{p}$.

Conger, C.L., 2005, Identification and characterization of sand deposit distribution on Oahu fringing reefs: Honolulu, Hawaii, University of Hawaii, unpublished Master's thesis, $99 \mathrm{p}$.

Conger, C.L., Fletcher, C., Hochberg, E.J., Frazer, L.N., and Rooney, J.J.B., 2009, Remote sensing of sand distribution across fringing reefs on Oahu, Hawaii: Marine Geology, v. 267 , no. $3-4$, p. $175-190$.

Conger, C.L., Hochberg, E.J., Fletcher, C., and Atkinson, M.J., 2006, Decorrelating remote sensing color bands from bathymetry in optically shallow waters: IEEE Transactions on Geoscience and Remote Sensing, v. 44, no. 6, p. 16551660 .

Coulbourn, W.T., Campbell, J.F., and Moberly, R., 1974, Hawaiian submarine terraces, canyons, and quaternary history evaluated by seismic-reflection profiling: Marine Geology, v. 17, no. 4, p. 215-234.

Coyne, M.A., Fletcher, C., and Richmond, B.M., 1999, Mapping coastal erosion hazard areas in Hawaii: Observation and Errors: Journal of Coastal Research, Special Issue 28, p. 171-184.
Coyne, M.A., Mullane, R.A., Fletcher, C., and Richmond, B.M., 1996, Losing Oahu: Erosion on the Hawaiian coast: Geotimes, v. 41, no. 12, p. 23-26.

Crowell, M., and Leatherman, S.P., eds., 1999, Coastal erosion mapping and management: Journal of Coastal Research, Special Issue 28, $196 \mathrm{p}$.

Crowell, M., Leatherman, S.P., and Buckley, M.K., 1991, Historical shoreline change: Error analysis and mapping accuracy: Journal of Coastal Research, v. 7, no. 3, p. $839-852$.

Daniels, R.C., and Huxford, R.H., 2001, An error assessment of vector data derived from scanned National Ocean Service topographic sheets: Journal of Coastal Research, v. 17, no. 3, p. 611-619.

Dolan, R., Anders, F., and Kimball, S., 1985, Coastal erosion and accretion, in National Atlas of the United States of America: Reston, Va., U.S. Geological Survey, 1 sheet, scale 1:7,500,000.

Dolan, R., Fenster, M.S., and Holme, S.J., 1991, Temporal analysis of shoreline recession and accretion: Journal of Coastal Research, v. 7, no. 3, p. 723-744.

Dollar, S.J., 1982, Wave stress and coral community structure in Hawaii: Coral Reefs, v. 1, no. 2, p. 71-81.

Dollar, S.J., and Tribble, G., 1993, Recurrent storm disturbance and recovery: A long-term study of coral communities in Hawaii: Coral Reefs, v. 12, no. 3-4, p. 223-233.

Douglas, B.C., Crowell, M., and Leatherman, S.P., 1998, Considerations for shoreline position prediction: Journal of Coastal Research, v. 14, no. 3, p. 1025-1033.

Dunbar, C.O., and Rodgers, J., 1957, Principles of stratigraphy: New York, John Wiley \& Sons, 356 p.

Ellis, M.Y., ed., 1978, Coastal mapping handbook: U.S. Department of Interior, U.S. Geological Survey, and U.S. Department of Commerce, National Ocean Survey, Washington, D.C., U.S. Government Printing Office, 199 p.

Engels, M.S., Fletcher, C., Field, M.E., Storlazzi, C.D., Grossman, E.E., Rooney, J.J.B., Conger, C.L., and Glenn, C., 2004, Holocene reef accretion: Southwest Molokai, Hawaii, U.S.A.: Journal of Sedimentary Research, v. 74 , no. 2 , p. $255-269$.

Eversole, D., and Fletcher, C., 2003, Longshore sediment transport rates on a reef-fronted beach: Field data and empirical models, Kaanapali Beach, Hawaii: Journal of Coastal Research, v. 19, no. 3, p. 649-663.

Feirstein, E.J., and Fletcher, C., comp., 2003, Hawaii, in Bird, E.C.F., ed., The world's coasts: Online: chap. 1.24, accessed June 1, 2011, at http://www.springerlink.com/ content/978-0-306-48369-1/. 
Firing, Y.L., and Merrifield, M.A., 2004, Extreme sea-level events at Hawaii: Influence of mesoscale eddies: Geophysical Research Letters, v. 31, no. L24306, 4 p.

Flament, P., Kennan, S., Lumpkin, R., Sawyer, M., and Stroup, E.D., 1996, Ocean atlas of Hawaii: Honolulu, Hawaii, University of Hawaii, Department of Oceanography, School of Ocean and Earth Science and Technology (poster).

Fletcher, C., 1992, Sea-level trends and physical consequences: Applications to the U.S. shore: Earth-Science Reviews, v. 33, no. 2, p. 73-109.

Fletcher, C., 2009, Sea level by the end of the 21 st century: A review: Shore and Beach, v. 77, no. 4, p. 4-12.

Fletcher, C., Bochicchio, C., Conger, C.L., Engels, M.S., Feirstein, E.J., Grossman, E.E., Grigg, R., Harney, J.N., Rooney, J.J.B., Sherman, C.E., Vitousek, S., Rubin, K., and Murray-Wallace, C.V., 2008, Geology of Hawaii reefs, in Riegl, B.M., and Dodge, R.E., eds., Coral reefs of the USA: New York, Springer, Inc., p. 435-488.

Fletcher, C., Boyd, R., Neal, W.J., and Tice, V., 2010, Living on the shores of Hawaii: Natural hazards, the environment, and our communities: Honolulu, Hawaii, University of Hawaii Press, 336 p.

Fletcher, C., and Feirstein, E.J., 2010, Hawaii, in Bird, E.C.F., Encyclopedia of the world's coastal landforms: Heidelberg, Springer Verlag, chap. 1.16.

Fletcher, C., Grossman, E.E., Richmond, B.M., and Gibbs, A.E., 2002, Atlas of natural hazards in the Hawaiian Coastal Zone: U.S. Geological Survey Geologic Investigations Series I-2761, 182 p.

Fletcher, C., and Jones, A.T., 1996, Sea level highstand recorded in Holocene shoreline deposits on Oahu, Hawaii: Journal of Sedimentary Research, v. 66, no. 3, p. 632-641.

Fletcher, C., and Lemmo, S.J., 1999, Hawaii's emergent coastal erosion management program: Shore and Beach, v. 67 , no. 4 , p. $15-20$.

Fletcher, C., Mullane, R.A., and Richmond, B.M., 1997, Beach loss along armored shorelines on Oahu, Hawaiian Islands: Journal of Coastal Research, v. 13, no. 1, p. 209-215.

Fletcher, C., Murray-Wallace, C.V., Glenn, C.R., Sherman, C.E., Popp, B., and Hessler, A., 2005, Age and origin of Late Quaternary Eolianite, Kaiehu Point (Moomomi), Molokai, Hawaii: Journal of Coastal Research, Special Issue 42, p. 97-112.
Fletcher, C., Rooney, J., Barbee, M., Lim, S.-C., and Richmond, B., 2003, Mapping shoreline change using digital orthophotogrammetry on Maui, Hawaii: Journal of Coastal Research, Special Issue 38, p. 106-124.

Fletcher, C., and Sherman, C.E., 1995, Submerged shorelines on Oahu, Hawaii: Archive of episodic transgression during the deglaciation?: Journal of Coastal Research, Special Issue 17, Holocene cycles: Climate, sea level, and coastal sedimentation, p. 141-152.

Frazer, L.N., Genz, A.S., and Fletcher, C., 2009, Toward parsimony in shoreline change prediction (I): Basis function methods: Journal of Coastal Research, v. 25, no. 2, p. 366-379.

Galgano, F.A., Douglas, B.C., and Leatherman, S.P., 1998, Trends and variability of shoreline position: Journal of Coastal Research, Special Issue 26, p. 282-291.

Genz, A.S., Fletcher, C., Dunn, R.A., Frazer, L.N., and Rooney, J.J., 2007a, The predictive accuracy of shoreline change rate methods and alongshore beach variation on Maui, Hawaii: Journal of Coastal Research, v. 23, no. 1, p. $87-105$.

Genz, A.S., Frazer, L.N., and Fletcher, C., 2007b, Improving statistical validity in calculating erosion hazards from historical shorelines, in Kraus, N.C., and Rosati, J.D., Coastal Sediments '07: Proceedings of the 6th International Symposium on Coastal Engineering and Science of Coastal Sediment Processes: American Society of Civil Engineers, New Orleans, La., May 13-17, 2007, p. 1799-1812.

Genz, A.S., Frazer, L.N., and Fletcher, C., 2009, Toward parsimony in shoreline change prediction (II): Applying basis function methods to real and synthetic data: Journal of Coastal Research, v. 25, no. 2, p. 380-392.

Giambelluca, T.W., and Schroeder, T.A., 1998, Climate, in Juvik, S.P., and Juvik, J.O., eds., Atlas of Hawaii (3d ed.): Honolulu, Hawaii, University of Hawaii Press, p. 49-59.

Gibbs, A.E., Richmond, B.M., Fletcher, C., and Hillman, K.P., 2001, Hawaii beach monitoring program: U.S. Geological Survey Open-File Report 01-308, version 1.0.

Gischler, E., and Lomando, A.J., 1999, Recent sedimentary facies of isolated carbonate platforms, Belize-Yucatan system, Central America: Journal of Sedimentary Research, v. 69 , no. 3 , p. $747-763$.

Goddard, L., and Graham, N.E., 1997, El Niño in the 1990s: Journal of Geophysical Research, v. 102, no. C5, p. 1042310436.

Graham, N.E., and Diaz, H.F., 2001, Evidence for intensification of North Pacific winter cyclones since 1948: Bulletin of the American Meteorological Society, v. 82, no. 9, p. 1869-1893. 
Grigg, R.W., 1983, Community structure, succession and development of coral reefs in Hawaii: Marine Ecology_ Progress Series, v. 11, p. 1-14.

Grigg, R.W., 1998, Holocene coral reef accretion in Hawaii: A function of wave exposure and sea level history: Coral Reefs, v. 17, no. 3, p. 263-272.

Grossman, E.E., Barnhardt, W.A., Richmond, B.M., and Field, M.E., 2006, Shelf stratigraphy and the influence of antecedent substrate on Holocene reef development, South Oahu, Hawaii: Marine Geology, v. 226, no. 1-2, p. 97-114.

Grossman, E.E., and Fletcher, C., 1998, Sea level higher than present 3500 years ago on the northern main Hawaiian Islands: Geology, v. 26, no. 4, p. 363-366.

Grossman, E.E., and Fletcher, C., 2004, Holocene reef development where wave energy reduces accommodation space, Kailua Bay, windward Oahu, Hawaii, U.S.A.: Journal of Sedimentary Research, v. 74, no. 1, p. 49-63.

Hapke, C.J., and Reid, D., 2007, National assessment of shoreline change: Part 4: Historical coastal cliff retreat along the California Coast: U.S. Geological Survey Open-File Report 2007-1133, 57 p. (Also available at http://pubs.usgs.gov/ of/2007/1133/.)

Hapke, C.J., Reid, D., Richmond, B.M., Ruggiero, P., and List, J., 2006, National assessment of shoreline change: Part 3: Historical shoreline change and associated coastal land loss along sandy shorelines of the California Coast: U.S. Geological Survey Open-File Report 2006-1219, 79 p. (Also available at $\mathrm{http}: / /$ pubs.usgs.gov/of/2006/1219/.)

Harney, J.N., and Fletcher, C., 2003, A budget of carbonate framework and sediment production, Kailua Bay, Oahu, Hawaii: Journal of Sedimentary Research, v. 73, no. 6, p. $856-868$.

Harney, J.N., Grossman, E.E., Richmond, B.M., and Fletcher, C., 2000, Age and composition of carbonate shoreface sediments, Kailua Bay, Oahu, Hawaii: Coral Reefs, v. 19, no. 2, p. 141-154.

The H. John Heinz III Center for Science, Economics, and the Environment, 2000, Evaluation of erosion hazards: Washington, D.C., The H. John Heinz III Center for Science, Economics, and the Environment, 205 p.

Hwang, D.J., 1981, Beach changes on Oahu as revealed by aerial photographs: Honolulu, Hawaii, State of Hawaii Department of Planning and Economic Development: Honolulu, Hawaii, Coastal Zone Management Program, Technical Supplement 22, 146 p.
Hwang, D.J., 2005, Hawaii coastal hazard mitigation guidebook: Honolulu, Hawaii, University of Hawaii Hawaii Coastal Zone Management Program, Office of Planning, Department of Business, Economic Development \& Tourism, State of Hawaii, 216 p.

Inman, D.L., 1952, Measures for describing the size distribution of sediments: Journal of Sedimentary Research, v. 22, no. 3, p. 125-145 (Also available at http://jsedres.sepmonline.org/cgi/reprint/22/3/125.pdf.)

Kaminsky, G.M., Ruggiero, P., and Gelfenbaum, G.R., 1998, Monitoring coastal change in southwest Washington and northwest Oregon during the 1997/98 El Niño: Shore and Beach, v. 66 , no. 3 , p. $42-51$.

Kench, P.S., 1997, Contemporary sedimentation in the Cocos (Keeling) Islands, Indian Ocean: Interpretation using settling velocity analysis: Sedimentary Geology, v. 114, no. $1-4$, p. 109-130.

Kraft, J., and Brown, H.F., 1982, Terrigenous and carbonate clastic facies in a transgressive sequence over volcanic terrain (abstract): American Association of Petroleum Geologists Bulletin, v. 66, no. 5, p. 589.

Macdonald, G.A., Abbott, A.T., and Peterson, F.L., 1983, Volcanoes in the sea: The geology of Hawaii (2d ed.): Honolulu, Hawaii, University of Hawaii Press, 523 p.

Macdonald, G.A., Davis, D.A., and Cox, D.C., 1960, Geology and ground-water resources of the island of Kauai, Hawaii: Hawaii Division of Hydrography, Bulletin 13, 212 p.

Makai Ocean Engineering and Sea Engineering, 1991, Aerial photograph analysis of coastal erosion on the islands of Kauai, Molokai, Lanai, Maui and Hawaii: Honolulu, Hawaii, Office of State Planning, Coastal Zone Management Program, 200 p.

Mantua, N.J., Hare, S.R., Zhang, Y., Wallace, J.M., and Francis, R.C., 1997, A Pacific interdecadal climate oscillation with impacts on salmon production: Bulletin of the American Meteorological Society, v. 78, no. 6, p. 1069-1079.

Merrifield, M.A., Merrifield, S.T., and Mitchum, G.T., 2009, An anomalous recent acceleration of global sea-level rise: Journal of Climate, v. 22, no. 21, p. 5772-5781.

Miller, T.L., and Fletcher, C., 2003, Waikiki: Historical analysis of an engineered shoreline: Journal of Coastal Research, v. 19 , no. 4 , p. $1026-1043$.

Moberly, R., 1963, Coastal geology of Hawaii: Honolulu, Hawaii, University of Hawaii, Hawaii Institute of Geophysics Report 41, 216 p.

Moberly, R., 1968, Loss of Hawaiian littoral sand: Journal of Sedimentary Petrology, v. 38, no. 1, p. 17-34. 
Moberly, R., Campbell, J.F., and Coulbourn, W.T., 1975, Offshore and other sand resources for Oahu, Hawaii: Honolulu, Hawaii, University of Hawaii, Hawaii Institute of Geophysics Report 75-10, 36 p.

Moberly, R., Jr., and Chamberlain, T., 1964, Hawaiian beach systems: Honolulu, Hawaii, University of Hawaii, Hawaii Institute of Geophysics Report 64-2, 95 p.

Moore, J.G., 1987, Subsidence of the Hawaiian Ridge, in Decker, R.W., Wright, T.L., and Stauffer, P.H., eds., Volcanism in Hawaii: U.S. Geological Survey Professional Paper 1350, p. 85-100.

Moore, L.J., and Griggs, G.B., 2002, Long-term cliff retreat and erosion hotspots along the central shores of the Monterey Bay National Marine Sanctuary: Marine Geology, v. 181 , no. $1-3$, p. $265-283$.

Moore, L.J., Rugiero, P., and List, J.H., 2006, Comparing mean high water and high water line shorelines: Should proxy-datum offsets be incorporated in shoreline change analysis?: Journal of Coastal Research, v. 22, no. 4, p. 894-905.

Morton, R.A., and Miller, T.A., 2005, National assessment of shoreline change: Part 2: Historical shoreline changes and associated coastal land loss along the U.S. Southeast Atlantic Coast: U.S. Geological Survey Open-File Report 2005-1401, 35 p. (Also available at http://pubs.usgs.gov/ of/2005/1401/.)

Morton, R.A., Miller, T.A., and Moore, L.J., 2004, National assessment of shoreline change: Part 1: Historical shoreline changes and associated coastal land loss along the U.S. Gulf of Mexico: U.S. Geological Survey Open-File Report 2004-1043, 42 p. (Also available at http://pubs.usgs.gov/of/2004/1043/.)

National Aeronautics and Space Administration, 2011, Global climate change: NASA's eyes on Earth: accessed May 26, 2011, at http://climate.nasa.gov/keyIndicators/ index.cfm\#SeaLevel.

National Oceanographic and Atmospheric Administration, 2011, NOAA tides \& currents: accessed May 26, 2011, at http://tidesandcurrents.noaa.gov/.

National Research Council, Committee on Coastal Erosion Zone Management, 1990, Managing coastal erosion: Washington, D.C., National Academy Press, 182 p.

Norcross, Z.M.N., Fletcher, C., and Merrifield, M., 2002, Annual and interannual changes on a reef-fringed pocket beach: Kailua Bay, Hawaii: Marine Geology, v. 190, no. 3-4, p. 553-580.
Norcross, Z.M.N., Fletcher, C., Rooney, J.J.R., Eversole, D., and Miller, T.L., 2003, Hawaiian beaches dominated by longshore transport, in Davis, R.A., Sallenger, A., and Howd, P., Coastal Sediments '03: Proceedings of the Fifth International Symposium on Coastal Engineering and Science of Coastal Sediment Processes: Clearwater Beach, Fla., May 18-23, 2003.

Purdy, E.G., 1974, Reef configurations: Cause and effect, in Laporte, L.F., ed., Reefs in time and space: Society of Economic Paleontologists and Mineralogists, v. 18, p. 9-76.

Resig, J.M., 2004, Age and preservation of Amphistegina (foraminifera) in Hawaiian beach sand: Implication for sand turnover and resource renewal: Marine Micropaleontology, v. 50, no. 3-4, p. 225-236.

Richmond, B.M., Fletcher, C., Grossman, E.E., and Gibbs, A.E., 2001, Islands at risk: Coastal hazard assessment and mapping in the Hawaiian islands: Environmental Geosciences, v. 8, no. 1, p. 21-37.

Romine, B.M., Fletcher, C., Frazer, L.N., Genz, A.S., Barbee, M.M., and Lim, S.-C., 2009, Historical shoreline change, Southeast Oahu, Hawaii: Applying polynomial models to calculate shoreline change rates: Journal of Coastal Research, v. 25, no. 6, p. 1236-1253.

Romine, B.M., Fletcher, C., Genz, A.S., Barbee, M.M., Dyer, M., Anderson, T.R., Lim, S.C., Vitousek, S., Bochicchio, C., and Richmond, B.M., 2011, National assessment of shoreline change: A GIS compilation of vector shorelines and associated shoreline change data for the Hawaiian Islands: U.S. Geological Survey OpenFile Report 2011-1009, available at http://pubs.usgs.gov/ of/2011/1009/.

Rooney, J.J.B., and Fletcher, C., 2000, A high resolution, digital, aerial photogrammetric analysis of historical shoreline change and net sediment transport along the Kihei Coast of Maui, Hawaii, in Proceedings of the Thirteenth Annual National Conference on Beach Preservation Technology: Melbourne, Fla., February 2-4, 2000, p. 281-296.

Rooney, J.J.B., and Fletcher, C., 2005, Shoreline change and Pacific climatic oscillations in Kihei, Maui, Hawaii: Journal of Coastal Research, v. 21, no. 3, p. 535-547.

Rooney, J.J.B., Fletcher, C., Barbee, M.M., Eversole, D., Lim, S.-C., Richmond, B.M., and Gibbs, A., 2003, Dynamics of sandy shorelines in Maui, Hawaii: Consequences and causes, in Davis, R.A., Sallenger, A., and Howd, P., Coastal sediments '03: Proceedings of the Fifth International Symposium on Coastal Engineering and Science of Coastal Sediment Processes, Clearwater Beach, Fla., May 18-23, 2003. 
Rooney, J.J.B., Fletcher, C., Grossman, E., Engels, M., and Field, M., 2004, El Niño influence on Holocene reef accretion in Hawaii: Pacific Science, v. 58, no. 2, p. 305-324.

Ruggiero, P., Kaminsky, G.M., Gelfenbaum, G., and Voight, B., 2005, Seasonal to interannual morphodynamics along a high-energy dissipative littoral cell: Journal of Coastal Research, v. 21, no. 3, p. 553-578.

Ruggiero, P., Kaminsky, G.M., Komar, P.D., and McDougal, W.G., 1997, Extreme waves and coastal erosion in the Pacific Northwest, in Edge, B.L., and Hemsley, J.M., eds., Ocean Wave Measurement and Analysis: Proceedings of the Third International Symposium, Waves '97: American Society of Civil Engineers, Virginia Beach, Va., November 3-7, 1997, p. 947-961.

Sea Engineering, Inc., 1988, Oahu shoreline study: Honolulu, Hawaii, City and County of Honolulu Department of Land Utilization, $61 \mathrm{p}$.

Seymour, R.J., 1998, Effect of El Niños on west coast wave climate: Shore and Beach, v. 66, p. 3-6.

Seymour, R.J., Strange, R.R., III, Cayan, D.R., and Nathan, R.A., 1984, Influence of El Niños on California's wave climate, in Edge, B.L., ed., Nineteenth Coastal Engineering Conference: Proceedings of the International Conference, American Society of Civil Engineers, Houston, Tex., September 3-7, 1984, p. 577-592.

Shalowitz, A.L., 1964, Shore and sea boundaries: Interpretation and use of Coast and Geodetic Survey data: U.S. Department of Commerce, Coast and Geodetic Survey, Publication 10-1, v. 2, 749 p., available at http://www.nauticalcharts.noaa.gov/hsd/shalowitz.html.

Sherman, C.E., Fletcher, C., and Rubin, K.H., 1999, Marine and meteoric diagenesis of Pleistocene carbonates from a nearshore submarine terrace, Oahu, Hawaii: Journal of Sedimentary Research, v. 69, no. 5, p. 1083-1097.

Stauble, D.K., and Brumbaugh, R.W., 2003, An assessment of the nation's shorelines, USA: Shore and Beach, v. 71, no. 3, p. 11-18.

Stearns, H.T., 1935, Shore benches on the island of Oahu, Hawaii: The Geological Society of America Bulletin, v. 46, p. 1467-1482.

Stearns, H.T., and Vaksvik, K.N., 1935, Geology and groundwater resources of the island of Oahu, Hawaii: Hawaii Division of Hydrography Bulletin 1, 479 p.
Storlazzi, C.D., Field, M.E., Dykes, J.D., Jokeil, P.L., and Brown, E., 2002, Wave control on reef morphology and coral distribution: Molokai, Hawaii, in WAVES 2001 Conference Proceedings, American Society of Civil Engineers, San Francisco, Calif., v. 1, p. 784-793.

Storlazzi, C.D., and Griggs, G.B., 2000, Influence of El Niño-Southern Oscillation (ENSO) events on the evolution of central California's shoreline: Geological Society of America Bulletin, v. 112, no. 2, p. 236-249.

Thieler, E.R., Himmelstoss, E.A., Zichichi, J.L., and Ergul, A., 2009, The Digital Shoreline Analysis System (DSAS) version 4.0 - An ArcGIS extension for calculating shoreline change: U.S. Geological Survey Open-File Report 20081278 (Also available at http://woodshole.er.usgs.gov/ project-pages/dsas/version4/.)

U.S. Army Corps of Engineers, 1971, Report on the National Shoreline Study: Washington, D.C., 62 p. (Also available at http://nationalshorelinemanagement.us/ docs/Shoreline_Study_1971.pdf.)

U.S. Bureau of the Budget, 1947, United States National Map Accurracy Standards: U.S. Bureau of the Budget, Washington, D.C., 1 p. (Also available at http://rmmcweb.cr.usgs.gov/nmpstds/acrodocs/nmas/ NMAS647.PDF.)

Vermeer, M., and Rahmstorf, S., 2009, Global sea level linked to global temperature: Proceedings of the National Academy of Sciences, v. 106, no. 51, p. 21527-21532.

Vitousek, S., and Fletcher, C., 2008, Maximum annually recurring wave heights in Hawaii: Pacific Science, v. 62, no. 4, p. 541-553.

Vitousek, S., Fletcher, C., Merrifield, M.A., Pawlak, G., and Storlazzi, C.D., 2007, Model scenarios of shoreline change at Kaanapali Beach, Maui, Hawaii: Seasonal and extreme events: Coastal Sediments '07, American Society of Civil Engineers, New Orleans, La., p. 1227-1240.

Wang, X.L., and Swail, V.R., 2001, Changes of extreme wave heights in Northern Hemisphere oceans and related atmospheric circulation regimes: Journal of Climate, v. 14, no. 10 , p. 2204-2221.

Wentworth, C.K., 1922, A scale of grade and class terms for clastic sediments: Journal of Geology, v. 30, no. 5, p. 377-392.

Zhang, Y., Wallace, J.M., and Battisti, D.S., 1997, ENSO-like interdecadal variability: 1990-93: Journal of Climate, v. 10, no. 5, p. 1004-1020. 
Prepared by the Pembroke and West Trenton Publishing Service Centers.

For more information concerning this report, contact:

Director

U.S. Geological Survey

Woods Hole Coastal and Marine Science Center 384 Woods Hole Road

Quissett Campus

Woods Hole, MA 02543-1598

WHSC_science_director@usgs.gov

508-548-8700 or 508-457-2200

or visit our Web site at:

http://woodshole.er.usgs.gov/ 


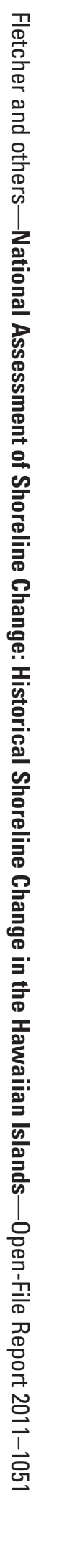

